Fernando Cruz de Moraes

\title{
INFLUÊNCIA DA MICROESTRUTURA DOS AÇOS INOXIDÁVEIS (AUSTENÍTICOS, FERRÍTICOS E MARTENSÍTICOS) NA PROTEÇÃO CONTRA A CORROSÃO POR FILMES DE POLIANILINA.
}

Dissertação apresentada ao Instituto de Química de São Carlos, da Universidade de São

Paulo para obtenção do título de Mestre em Ciências (FísicoQuímica).

Orientador: Prof. Dr. Artur de Jesus Motheo 


\section{AGRADECIMENTOS}

- A Deus acima de todas as coisas.

- Ao Prof. Dr. Artur de Jesus Motheo pela orientação, dedicação, sugestões, por sempre ser solícito as minhas necessidades e principalmente pela confiança depositada.

- Ao IQSC-USP e a todos funcionários que contribuíram para a realização deste trabalho.

- A Sandra, Fábio, Rodrigo e Miwa pelas valiosas discussões, auxílio nos experimentos e apoio nas horas complicadas.

- Aos amigos do LEQI: Geoff, Eveline, Luciano, Karen, Tatiane, Leandro, Josias (Gerardinho), Dani e até o Álvaro.

- Aos antigos amigos da UFSCar, Araraquara e do IQSC, que fizeram parte do meu passado e juntos com os amigos do presente serão parte da minha história.

- A minha família: Mãe, Pai, André e Cris, que acreditaram em mim e me deram todo tipo de suporte: amor, carinho e financeiro.

- Minha nova família D. Ivani, Sr. Jerônimo, Viviam e João, por serem almas abençoadas.

- E principalmente, a Ivana pelo amor, carinho, confiança, dedicação, apoio, cobranças e por ser minha alegria. 


\section{Índice}

Capítulo 1 Introdução .................................................................01

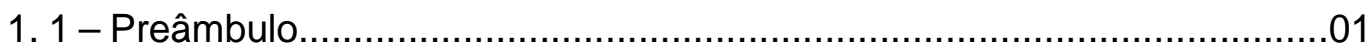

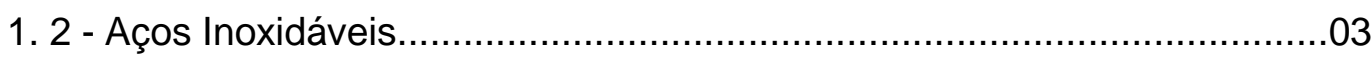

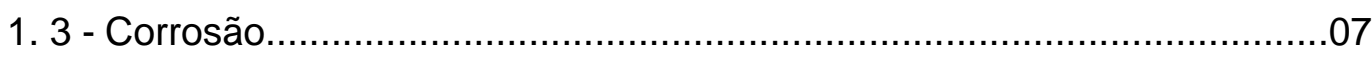

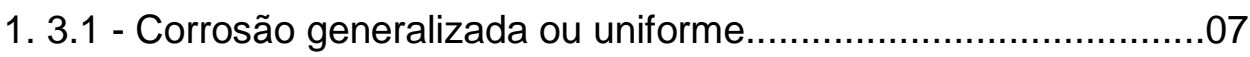

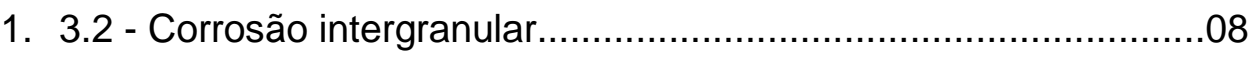

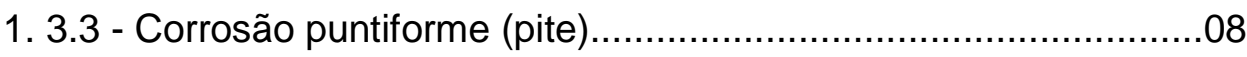

1.4 - Proteção contra a corrosão............................................................10

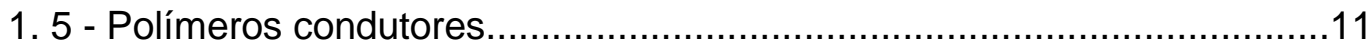

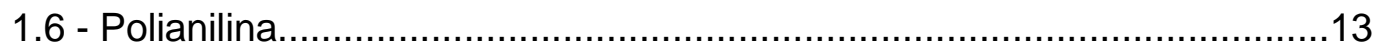

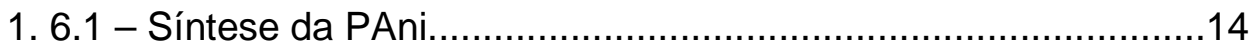

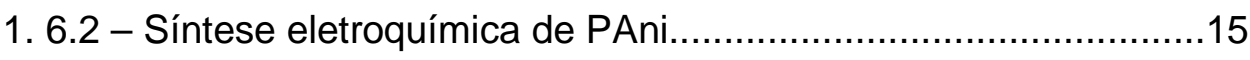

1. 6.3 - Polianilina como agente protetor contra a corrosão..................16

Capítulo 2 Objetivos....................................................................19

Capítulo 3 Experimental ..................................................................20

3. 1 - Construção e tratamento prévio dos eletrodos........................................20

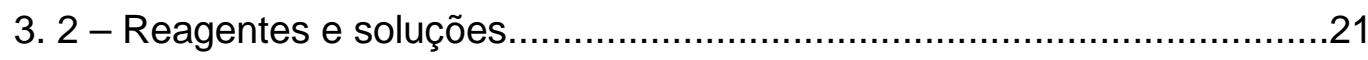

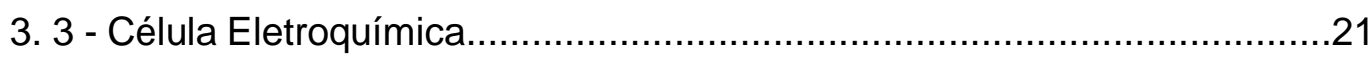

3. 4 - Análise das composições nominais dos aços inoxidáveis.....................22

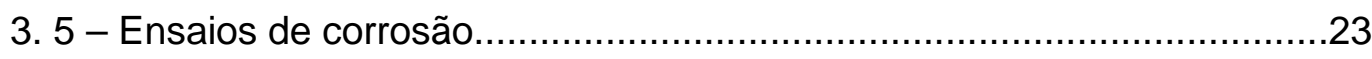

3. 5.1 - Polarização potenciodinâmica...............................................23

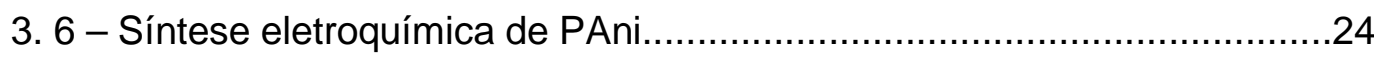

3. 6.1 - Voltametria cíclica................................................................24 
3. 6.2 - Eletropolimerização de PAni, sobre os eletrodos de aços

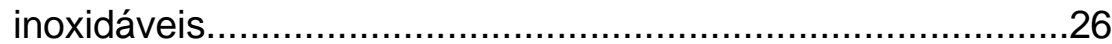

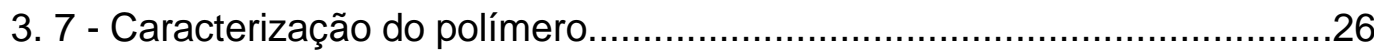

3.7.1 - Espectroscopia na região do ultravioleta- visível e infravermelho

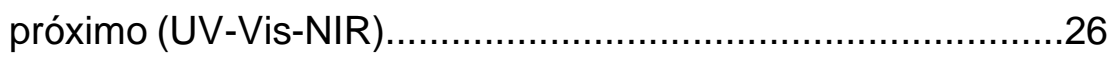

3. 7.2 - Espectroscopia na região do infravermelho (IV).....................27

3. 7.3 - Microscopia eletrônica de varredura (MEV)...........................28

3. 8 - Comparação da eletropolimerização de PAni sobre os aços inoxidáveis .29

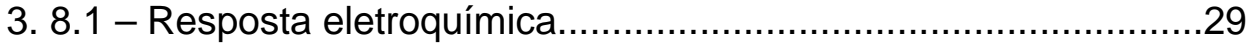

3. 8.2 - Espectroscopia de impedância eletroquímica (EIS).................30

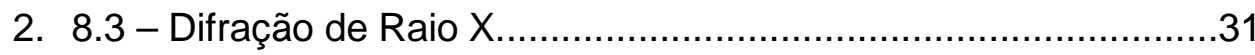

\section{Capítulo 4 Resultados e Discussão....................................................33}

4. 1 - Síntese e caracterização de PAni eletropolimerizada.............................33

4. 1.1 - Eletropolimerização de PAni ..................................................34

4. 1.2 - Caracterização do filme de PAni..........................................37

4. 1.2.1 - Resposta eletroquímica............................................37

4. 1.2.2 - Espectroscopia na região do UV-vis-NIR....................38

4. 1.2.3- Espectroscopia no infravermelho (IV).......................40

4. 1.2.4 - Microscopia eletrônica de varredura (MEV)...............41

4. 2 - Estudo da formação do filme de PAni...................................................43

4. 2.1 - Estudo comparativo das cargas totais anódicas, difração de

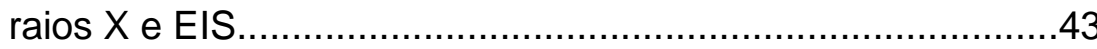

4. 3 Proposição do mecanismo de eletropolimeriz. do filme de PAni...............53 4.3 - Curvas de polarização para aos aços inox. sem recobrimento...............54

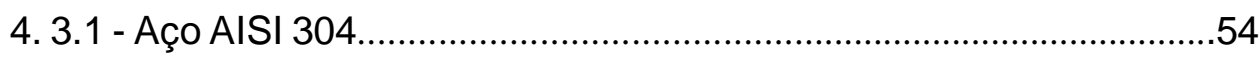

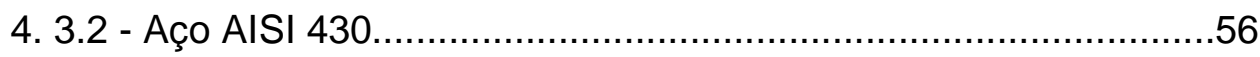

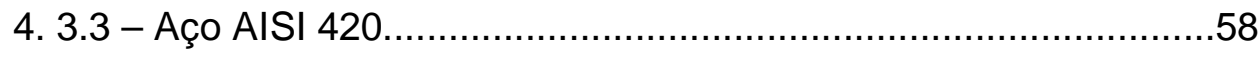

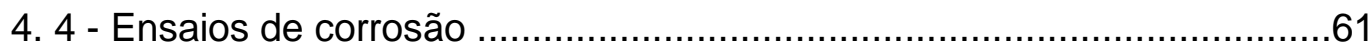

4. 4.1 - Ensaios de corrosão com o aço AISI 304 .................................62

4. 4.2 - Ensaios de corrosão com o aço AISI 430..................................64 
4. 4.3 - Ensaios de corrosão com o aço AISI 420............................66

3. 5 - Considerações gerais..............................................................68

Capítulo 5 Conclusões e Propostas para trabalhos futuros..............71

5. 1 - Conclusões............................................................................. 71

4. 2 - Propostas futuras............................................................

Referências Bibliográficas.................................................................74 


\section{Índice de figuras}

Figura 1 - (A) Chapa sem corrosão e (B) chapa com corrosão uniforme. .08

Figura 2 - (A) Micrografia de uma chapa com corrosão intergranular e (B) Vista da área exposta de um chapa com corrosão intergranular. .08

Figura 3 - Representação da corrosão por pites em um estagio intermediário: (A) vista superficial de uma chapa de aço inoxidável com corrosão por pite e (B) corte lateral de uma chapa de aço inoxidável com corrosão por pite. .09

Figura 4 - Representação estrutural dos diferentes estados de oxidação da polianilina. 13

Figura 5 - Esquema da célula eletroquímica onde, (a) é o eletrodo de trabalho (chapa de aço inoxidável), (b) eletrodo de referência (ECS) e (c) contra eletrodo (chapa de platina)

Figura 6 - Parâmetros de corrosão extraídos de uma curva de polarização anódica 23

Figura 7 - (a) Variação do potencial com o tempo e (b) curva resultante da corrente por potencial em um voltamograma cíclico típico. .25

Figura 8 - Voltamogramas cíclico da primeira etapa de eletropolimerização de PAni sobre os aços: (A) AISI 304; (B) AISI 430 e (C) AISI 420, com velocidade de varredura de $50 \mathrm{mV} \mathrm{s}^{-1}$...... .35

Figura 9 - Voltamogramas: (-) 30 ciclos e (…*) último ciclo da eletropolimerização do filme de PAni sobre (A) aço AISI 304, (B) AISI 430 e (C) AISI 430, com velocidade de varredura de $50 \mathrm{mV} \mathrm{s}^{-1}$ .36 
Figura 10 - Demonstração do $5^{\circ}$ ciclo da resposta eletroquímica dos filmes de PAni eletropolimerizados, em ácido oxálico $0,3 \mathrm{~mol} \mathrm{~L}^{-1}$, sobre os aços: (a) AISI 304, (b) AISI 430 e (c) AISI 420, com velocidade de varredura de $50 \mathrm{mV} \mathrm{s}^{-1}$

Figura 11 - Espectro de absorção de UV-vis-NIR de PAni, na forma desdopada para os aços AISI $304(-)$, AISI $430(-)$ e AISI $420(-)$

Figura 12 - Espectro de absorção de UV-vis-NIR de PAni, na forma dopada para os aços AISI $304(-)$, AISI $430(-)$ e AISI $420(-)$. 39

Figura 13 - Espectro de absorção de PAni no infravermelho (IV), na forma desdopada para os aços: (A) AISI 304, (B) AISI 430 e (C) AISI 420. . .40

Figura 14 - Espectro de absorção de PAni no infravermelho (IV), na forma dopada para os aços: (A) AISI 304, (B) AISI 430 e (C) AISI 420 41

Figura 15 - Micrografias dos filmes de PAni eletropolimerizados em ácido oxálico $0,3 \mathrm{~mol} \mathrm{~L}^{-1}$ sobre os aços (a) AISI 304, (b) AISI 430 e (c) AISI 420. Ampliação de 10.000 vezes. 42

Figura 16- (a) Voltamograma do $1^{\circ}$ ciclo dos aços inoxicáveis: (A) AISI 304, (B) AISI 430 e (C) AISI 420. Na presença de solução de ácido oxálico $0,3 \mathrm{~mol} \mathrm{~L}^{-1}$ contendo $0,1 \mathrm{~mol} \mathrm{~L}^{-1}$ de anilina, com velocidade de varredura de $50 \mathrm{mV} \mathrm{s}^{-1}$. 44

Figura 17 - Estudo do comparativo das cargas totais anódicas, obtidas a partir dos voltamogramas apresentados na Figura 16, para os aços inoxidáveis AISI 304, AISI 430 e AISI 420.

Figura 18 - Variação do número de ciclos em relação à carga de formação do sal esmeraldina para os aços: AISI 420,' AISI 430 e AISI 304. Inserção dos voltamogramas cíclicos do eletropolimerização de PAni - detalhe da área de cálculo da carga do processo de formação do sal esmeraldina 46 
Figura 19 - Voltamograma do $5^{\circ}$ ciclo dos aços inoxidáveis: (A) AISI 304, (B) AISI 430 e (C) AISI 420. Na presença de solução de ácido oxálico $0,3 \mathrm{~mol} \mathrm{~L}^{-1}$ isenta de anilina, com velocidade de $50 \mathrm{mV} \mathrm{s}^{-1}$

Figura 20 - Estudo do comparativo das cargas totais anódicas, obtidas a partir dos voltamogramas apresentados na Figura 25, para os aços inoxidáveis AISI 304, AISI 430 e AISI 420 48

Figura 21 - Difratograma de raios X para o aço AISI 420, recoberto com filme de PAni, mostrando os planos de difração para o oxalato de ferro. 49

Figura 22 - Difratograma de raios X para o aço AISI 430, recoberto com filme de PAni, mostrando os planos de difração para o oxalato de ferro. 49

Figura 23 - Diagramas de Nyquist, para aços recobertos com filme de oxalato: (a) aço AISI 420 e (b) $\Upsilon$ AISI 304 e AISI 430 .51

Figura 24 - Diagramas de Nyquist, para aços recobertos com filme de PAni: (a) aço AISI 420 e (b) $\Upsilon$ AISI 304 e AISI 430. .52

Figura 25 - Esquema de proposição do mecanismo de eletropolimerização de PAni sobre os aços inoxidáveis. 53

Figura 26- Curva de polarização potenciodinâmica do aço AISI 304, em solução de $\mathrm{NaCl} 3 \%$, com velocidade de varredura de $0,5 \mathrm{mVs}^{-1}$ .55

Figura 27 - Microscopia eletrônica de varredura, com aumento de 1000 vezes, para: (a) aço AISI 304 antes da polarização e (b) após a polarização potenciodinâmica. .56 
Figura 28 - Curva de polarização potenciodinâmica do aço AISI 430, em solução de $\mathrm{NaCl} 3 \%$, com velocidade de varredura de $0,5 \mathrm{mVs}^{-1}$ 57

Figura 29 - Microscopia eletrônica de varredura, com aumento de 1000 vezes, para: (a) aço AISI 430 antes da polarização e (b) após a polarização potenciodinâmica. 58

Figura 30- Curva de polarização potenciodinâmica do aço AISI 420, em solução de $\mathrm{NaCl} 3 \%$, com velocidade de varredura de $0,5 \mathrm{mVs}^{-1}$. .59

Figura 31- Microscopia eletrônica de varredura, com aumento de 1000 vezes, para: (a) aço AISI 420 antes da polarização e (b) após a polarização potenciodinâmica. 60

Figura 32 - Curva de polarização potenciodinâmicas, em solução de $\mathrm{NaCl} 3 \%$ aerado, com velocidade de varredura de $0,5 \mathrm{mV} \mathrm{s}^{-1}$, para o aço AISI 304: ( - sem revestimento, $(-)$ revestido com PAni dopado e $(-)$ revestido com PAni desdopado 63

Figura 33- Micrografia do aço AISI 304 recoberto com filme de PAni no estado desdopado: (a) aço após filme de PAni ser retirado, (b) aço recoberto com filme de PAni. Ampliação de 10.000 vezes. 64

Figura 34 - Curva de polarização potenciodinâmicas, em solução de $\mathrm{NaCl} 3 \%$ aerado, com velocidade de varredura de $0,5 \mathrm{mV} \mathrm{s}^{-1}$, para o aço AISI 430: ( - sem revestimento, $(-)$ revestido com PAni dopado e $(-)$ revestido com PAni desdopado 65

Figura 35 - Micrografia do aço AISI 430 recoberto com filme de PAni no estado desdopado: (a) aço após filme de PAni ser retirado, (b) aço recoberto com filme de PAni. Ampliação de 10.000 vezes 66 
Figura 36 - Curva de polarização potenciodinâmicas, em solução de $\mathrm{NaCl} 3 \%$ aerado, com velocidade de varredura de $0,5 \mathrm{mV} \mathrm{s}^{-1}$, para o aço AISI 420: ( - ) sem revestimento, $(-)$ revestido com PAni dopado e $(-)$ revestido com PAni

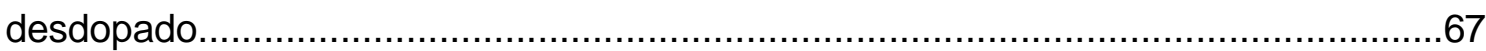

Figura 37 - Micrografia do aço AISI 420 recoberto com filme de PAni no estado desdopado: (a) filme de Pani e (b) aço sem recobrimento. Ampliação de 10.000 vezes. 


\section{Lista de tabelas}

Tabela I - Teores em porcentagem de massa, dos principais constituintes dos aços inoxidáveis

Tabela II - Composição nominal dos aços inoxidáveis em porcentagem de massa varredura de $50 \mathrm{mV} \mathrm{s}^{-1}$ 22

Tabela III - Parâmetros eletroquímicos obtidos através das curvas de polarização potenciodinâmica em solução de $\mathrm{NaCl} 3 \%$ aerada.

60

Tabela IV - Parâmetros eletroquímicos obtidos a partir das curvas de polarização potenciodinâmica para o aço AISI 304 63

Tabela V - Parâmetros eletroquímicos obtidos a partir das curvas de polarização potenciodinâmica para o aço AISI 430 .64

Tabela VI - Parâmetros eletroquímicos obtidos a partir das curvas de polarização potenciodinâmica para o aço AISI 430

Tabela VII - Variação dos parâmetros eletroquímicos obtidos das curvas de polarização potenciodinâmica. Relação entre ao aço revestido com PAni desdopada sem revestimento. 69 


\section{Resumo}

Neste trabalho foram obtidos filmes de polianilina (PAni) por eletropolimerização (voltametria cíclica) sobre aços inoxidáveis austenítico (AISI 304), ferrítico (AISI 430) e martensítico (AISI 420), em meio de ácido oxálico. Os filmes de PAni foram preparados a partir de solução aquosa de ácido oxálico $0,3 \mathrm{~mol} \mathrm{~L}^{-1}$ contendo 0,1 $\mathrm{mol} \mathrm{L}^{-1}$ de anilina a $50 \mathrm{mV} \mathrm{s}^{-1}$. Os valores de carga anódica total obtidos durante os estágios de eletropolimerização evidenciaram diferenças mecanísticas na polimerização da anilina sobre os diferentes aços. Os materiais poliméricos foram caracterizados por resposta eletroquímica, espectroscopias de impedância eletroquímica (EIS), de ultravioleta-visível (UV-vis-NIR), de infravermelho (IV), difração de raios $X(D R X)$, além de microscopia eletrônica de varredura (MEV). Os filmes de PAni sobre aço AISI 420, em relação aos demais aços, apresentam diferenças significativas de morfologia. Pode ser observado também que os aços com maior quantidade de cromo em sua composição, minimizam a formação de uma camada de oxalato de ferro, a qual é intermediária entre o metal e o filme de PAni. A camada de oxalato de ferro diminui as interações galvânicas entre o polímero e ferro do metal, promovendo a formação de filmes de PAni porosos e menos aderentes. A viabilidade de aplicação dos filmes de PAni dopados e desdopados, na proteção contra a corrosão dos aços inoxidáveis foi observada mediante polarização potenciodinâmica em solução aquosa de $\mathrm{NaCl}$. Os parâmetros eletroquímicos extraídos das curvas demonstraram que o filme de PAni, no estado desdopado, é o que protege mais efetivamente os aços AISI 304 e AISI 430 contra a corrosão. Com os ensaios de corrosão aliados a análises de EIS, foi proposto um mecanismo de deposição da PAni, o qual evidencia que a natureza do substrato metálico tem forte influência na formação dos filmes de PAni, quando a composição e a microestrutura dos aços diferem entre si. 


\begin{abstract}
In this work were obtained polyaniline films from electropolymerization for cyclic voltammeter, on different stainless steels: (AISI-304) austenitic, (AISI-430) ferritic and martensytic (AISI-420), in oxalic acid media. PAni-films were prepared from $0.3 \mathrm{~mol}$ $\mathrm{L}^{-1}$ oxalic acid containing $0.1 \mathrm{~mol} \mathrm{~L}^{-1}$ aniline at $50 \mathrm{mV} \mathrm{s}^{-1}$. The values of total anodic charge obtained during polymerization stages demontrated difference mechanistic in the aniline polymerization on different steels. Polymeric materials were characterized for electrochemistry response and different techniques: electrochemistry impedance (EIS), ultraviolet-visible (UV-vis-NIR), infrared (IR), ray-X diffraction spectroscopes and scanning electronic microscopy (SEM). PAni films on AISI-420 steel demonstrated significant differences in the morphology, when compared another steels. Also, can be observed that the steels with chromium high content in your composition minimize the formation of iron oxalate layer, which is intermediary between the metal and PAni films. Iron oxalate layer diminishes both the galvanic interactions between the polymer and iron ions of metal and it promotes both the porous PAni films formation and lower adherence. The application viability of PAni films, in both doped and undoped states, for the protection against corrosion of stainless steels was investigated for potentiodynamic polarization in $\mathrm{NaCl}$ aqueous solution. The electrochemistry parameters extracted of curves demonstrated that undoped PAni films protect the AISI-304 and AISI-430 against corrosion, more effectively. With the corrosion assays and EIS analysis can be proposed a mechanism of PAni deposition, which evidence that the metallic substrate nature has strong influence on PAni films electropolymerization when both the composition and the steels microstructure differ between them.
\end{abstract}




\section{Capítulo I}

\section{Introdução}

\section{1 - Preâmbulo}

Aços inoxidáveis são aqueles que contém um mínimo de 10,5\% de cromo como na liga e por este motivo, além da microestrutura cristalina e tratamento térmico são divididos em cinco classes: martensíticos, ferríticos, austeníticos, duplex (martensíticos e ferríticos) e endurecíveis por precipitação. São aços onde não sofrem oxidação em ambientes normais e suas características de resistência à corrosão são obtidas graças à formação de um óxido protetor que impede o contato do metal base com a atmosfera agressiva. Contudo, sofrem corrosão intergranular devido à formação de uma zona empobrecida em cromo ao longo do contorno de grão, como conseqüência da precipitação, neste local, carbonetos de cromo $\left(\mathrm{Cr}_{23} \mathrm{C}_{6}\right)$. Átomos de cromo desta região, que se encontravam na solução sólida no aço, difundem-se para os contornos de grão, formando carbonetos, diminuindo a resistência à corrosão. A formação desta zona empobrecida em cromo chama-se sensitização.

A sensitização depende do teor de carbono do aço e do tempo em certa temperatura. Os aços austeníticos sofrem sensitização quando expostos a temperaturas na faixa de 400 a $950{ }^{\circ} \mathrm{C}$, enquanto que os ferríticos somente para temperaturas acima de $925^{\circ} \mathrm{C}$. A exposição de um aço inoxidável sensitizado ao meio corrosivo não leva necessariamente à ocorrência da corrosão intergranular [1]. Muitos meios corrosivos como, por exemplo, ácido acético na temperatura ambiente, 
soluções alcalinas como carbonato de sódio ou ainda água potável não causam corrosão intergranular, por outro lado, os aços inoxidáveis formam uma camada protetora de hidróxidos de cromo e níquel em soluções ácidas. O principal problema desses aços é a corrosão localizada em ambientes contendo cloreto.

Os processos de corrosão promovem uma elevação significativa de custos financeiros de diferentes atividades industriais e não-industriais, além de poderem ocasionar acidentes graves. Existem vários métodos práticos adotados para diminuir a taxa de corrosão dos materiais metálicos, os quais segundo Vernon [2], podem ser baseados em modificações do processo, do meio corrosivo ou do metal, como também baseados em revestimentos protetores.

Da mesma forma, têm-se inibidores de corrosão que são substâncias, ou misturas de substância que, quando presentes em concentrações adequadas no meio corrosivo, reduzem ou eliminam a corrosão. Os inibidores podem ser empregados na decapagem ácida, limpeza química de caldeiras, industria petrolífera, sistemas de refrigeração, polimento de metais, proteção de alumínio, etc. Dentre os materiais protetores que vem sendo pesquisados para substituir os processos tradicionais que causam alto impacto ambiental encontram-se os filmes automontados e os polímeros condutores.

Os materiais poliméricos são usualmente conhecido por sua elevada resistividade elétrica, uma conseqüência básica das ligações covalentes saturadas ao longo de suas cadeias. Entretanto, há algumas décadas, foi observado que compostos com ligações conjugadas permitem um aumento de até 15 ordens de grandeza na condutividade elétrica, quando submetidos a processos de dopagem química ou eletroquímica [3], ou seja, dependendo do grau de dopagem, os polímeros condutores podem apresentar valores de condutibilidade elétrica tão díspares que vão desde isolantes até condutores. Esta nova classe de materiais poliméricos foi denominada de polímeros condutores.

Dentre os polímeros condutores mais estudados, a polianilina (PAni) e seus derivados [4,5] se destacam por apresentarem grandes possibilidades de aplicações. Esta versatilidade se deve a grande estabilidade química no estado dopado em condições ambientais, solubilidade, processabilidade, facilidade de dopagem e de polimerização. Outro fator extremamente interessante que tem sido observado é que 
a PAni e seus derivados podem ser misturados com outros polímeros [6-9] resultando em misturas com propriedades elétricas, mecânicas e químicas diferenciadas.

A proteção de aço carbono por filmes de PAni não-condutores, incluindo derivados, foi objeto de patente e posterior publicação, por McAndrew [10], baseada em medidas de resistência de poros por espectroscopia de impedância eletroquímica. Por outro lado, os aços inoxidáveis formam uma camada protetora de oxi-hidróxidos de cromo e níquel em soluções de ácidos inorgânicos. O principal problema desses aços é a corrosão localizada em ambientes contendo cloreto, sendo que, em um trabalho recente [11], pôde ser observado por curvas potenciodinâmicas que o filme de PAni tende a suprimir a corrosão por pites.

Desta forma, baseando-se nestas informações e em trabalhos realizados pelo Grupo de Eletroquímica Interfacial na área de polímeros condutores e de corrosão [12-14], se estudará o crescimento de um filme de um polímero condutor a base de PAni, eletroquimicamente sintetizado em meio de ácido oxálico, sobre aços inoxidáveis dos tipos: martensíticos, ferríticos e austeníticos, avaliar o filme de PAni dopado e desdopado como um revestimento protetor contra a corrosão em meio contendo íons cloreto.

\section{2 - Aços Inoxidáveis}

Aços inoxidáveis são definidos como ligas ferrosas que apresentam um teor mínimo de cromo de $11 \%$ em sua constituição [15]. A resistência à corrosão de um aço inoxidável depende da formação de um filme superficial fino de óxido de cromo $\left(\mathrm{CrO}_{3}\right)$, ou seja, esta resistência à corrosão resulta da presença do óxido de cromo ou hidreto na superfície do metal, que é estabilizada pelo cromo, protegendo o metal. Embora adições de 1 a 11\% de cromo ao aço já aumentam progressivamente a resistência à oxidação e a resistência a temperaturas ambiente e elevada, este filme fino de óxido de cromo é geralmente insuficiente para ambientes químicos muito corrosivos. Com mais de $11 \%$ de cromo já é obtida resistência a corrosão suficiente para a utilização do aço em ambientes mais agressivos [16].

Outros metais como níquel, cobre, silício, molibdênio e alumínio também são adicionados ao ferro para formar filmes protetores. O níquel segue o cromo em importância, pois não só contribui na resistência à corrosão como no melhoramento 
da resistência mecânica. O molibdênio geralmente aumenta a passividade e a resistência à corrosão nos ácidos sulfúrico e sulfuroso, a altas temperaturas e pressão, e na água do mar. Tanto o cobre como o silício, atuam no sentido de melhorar a resistência a ácido sulfúrico, sendo que o silício é adicionado quando se trabalha a altas temperaturas. Nitrogênio pode ser usado para se poder ter menor teor de níquel, por motivos econômicos, nos aços austeníticos.

Para aumentar a usinabilidade dos aços inoxidáveis, podem se admitir teores de enxofre, fósforo, selênio e telúrio acima de 0,07\%. O elemento mais importante é o enxofre que provoca aumento na usinabilidade pela formação de compostos intermetálicos (na forma de sulfetos) com outros elementos da liga, os quais provocam a quebra dos cavacos e possuem ação lubrificante [16]. Desta forma, diversos outros elementos têm sido incorporados sempre no sentido de melhorar a resistência dos aços inoxidáveis, sendo que cada um possui características específicas.

Os aços inoxidáveis são produzidos por fundição ou por trabalho mecânico e possuem as seguintes propriedades: resistência mecânica e tenacidade moderadas, relativas resistências ao calor, corrosão atmosférica e química em geral. Estes aços inoxidáveis podem ser classificados em três grandes grupos, de acordo com a composição química e microestrutura presente neles. A classificação dos aços inoxidáveis é: austeníticos, ferríticos, martensíticos e duplex (uma fase martensítica e uma fase ferrítica). Assim, os aços classificam-se em austeníticos, ferríticos, martensíticos [15]. A Tabela I a seguir mostra as composições da liga e os principais aços inoxidáveis de cada classe: 
Tabela I - Teores em porcentagem de massa, dos principais constituintes dos aços inoxidáveis.

\begin{tabular}{|c|c|c|c|c|c|c|c|c|}
\cline { 2 - 9 } \multicolumn{1}{c|}{} & \multicolumn{7}{c|}{ Teores dos constituintes da liga em \% } \\
\hline Classe & Tipo & C & Mn & Si & S & P & Cr & Ni \\
\hline Austeníticos & AISI 304 & 0,08 & 2,00 & 1,00 & 0,03 & 0,04 & 19,00 & 9,00 \\
Austeníticos & AISI $316^{*}$ & 0,08 & 2,00 & 1,00 & 0,03 & 0,04 & 17,00 & 12,50 \\
\hline Martensíticos & AISI 410 & 0,15 & 1,00 & 1,00 & 0,03 & 0,03 & 12,50 & \\
Martensíticos & AISI 420 & 0,15 & 1,00 & 1,00 & 0,03 & 0,03 & 13,00 & \\
\hline Ferríticos & AISI 430 & 0,12 & 1,25 & 1,00 & 0,03 & 0,04 & 17,00 & \\
Ferríticos & AISI 439 & 0,07 & 1,00 & 1,00 & 0,03 & 0,03 & 18,00 & \\
\hline
\end{tabular}

* Possui 3\% de molibdênio em sua composição

Os aços inoxidáveis apresentam boa resistência a corrosão, porém, em alguns casos outras características além da resistência a corrosão são necessárias para a utilização dos mesmos em determinadas aplicações, então são acrescidos outros elementos de liga para que o aço inoxidável adquira essas características. Uma grande melhoria em varias propriedades dos aços inoxidáveis é conseguida com a introdução de níquel como elemento de liga. Consegue-se uma mudança na estrutura, transformando ligas ferríticas em ligas austeníticas (estrutura de alta resistência e tenacidade).

Os aços inoxidáveis do tipo martensíticos, após resfriamento rápido a partir de alta temperatura, mostram uma estrutura caracterizando alta dureza e fragilidade, denominada martensita. Esta estrutura contém de 12 a $17 \%$ de cromo e 0,1 a $0,5 \%$ de carbono em sua constituição e podem atingir diversos graus de dureza pela variação de aquecimento e resfriamento. Os aços com esta estrutura são ferromagnéticos e dificilmente são atacados pela corrosão atmosférica. São suscetíveis a corrosão intergranular devido ao teor elevado de carbono em sua composição. Os aços inoxidáveis martensíticos são muito utilizados e os tipos comercialmente mais conhecidos são: AISI 420 e AISI 410. Devido à alta dureza estes aços são usados em cutelaria, instrumentos cirúrgicos e odontológicos, além de peças de turbinas aeronáuticas e máquinas industriais [17]. 
Após o resfriamento rápido de alta temperatura os aços inoxidáveis ferríticos mostram uma estrutura macia e tenaz, altamente homogênea, conhecida como ferrita. Contém de 16 a $30 \%$ de cromo em sua constituição. Não podem ser endurecidos por tratamento térmico e são basicamente usados na condição de recozidos. Possui maior resistência à corrosão que os aços martensíticos devido ao maior teor de cromo. Tem boas propriedades físicas e mecânicas e são efetivamente resistentes à corrosão atmosférica e a soluções fortemente oxidantes. São ferromagnéticos e apresentam tendência ao crescimento de grão após soldagem, particularmente para seções de grande espessura. A corrosão por pites e por frestas tem menor manifestação quando se adiciona cromo e molibdênio, onde a composição para garantir uma boa resistência é no mínimo $23 \%$ de cromo e $2 \%$ de molibdênio. Dentre os tipos de aços inoxidáveis ferríticos mais conhecidos destacam-se os tipos AISI 430 e AISI 439 utilizados como matéria-prima para caldeiras, reservatórios, fornos e queimadores, além de radiadores e peças decorativas [17].

Os aços inoxidáveis austeníticos são aqueles que contém simultaneamente cromo e níquel, como o teor de cromo variando de 16 a 26\% e o de níquel de 6 a $22 \%$. São conhecidos pela sua excelente resistência à corrosão em muitos meios agressivos. Outros elementos como molibdênio, titânio e nióbio, quando adicionados, proporcionam melhoras na resistência à corrosão e minimizar a corrosão intergranular por estabilização dos carbonetos. Dos três grupos, estes aços são os que apresentam maior resistência à corrosão. Combinam baixo limite de escoamento com alta resistência à tração e bom alongamento, oferecendo as melhores propriedades para trabalho a frio. Os aços austeníticos não são ferromagnéticos e não podem ser endurecidos por tratamento térmico. São considerados como sendo os mais resistentes a corrosão em ambientes industriais e em meios ácidos, mantendo a superfície brilhante e praticamente isenta de corrosão generalizada [17].

Os tipos de aços inoxidáveis austeníticos mais conhecidos comercialmente são os AISI: 301, 302, 304 e 316 e podem ter a designação 18-8, ou seja, possuem $18 \%$ de cromo e $8 \%$ de níquel [18]. São largamente utilizados em estruturas, 
utensílios domésticos, indústrias químicas, alimentícias e automobilísticas, além de equipamentos criogênicos.

\section{3 - Corrosão}

A corrosão pode ser definida como a deterioração de um metal que se dá na sua superfície por ação química ou eletroquímica do meio em que se encontra. $A$ deterioração de concreto, borracha, madeira e polímeros, ou seja, material não metálico, também é considerada como corrosão [19-21]. Alguns autores [2,22,23] consideram que o termo corrosão compreende todas as interações de materiais com diferentes meios. Sendo a corrosão um processo espontâneo, faz-se necessário o uso de mecanismos de proteção, pois os metais sofrem transformações, que ocasionam a perda da sua função.

A corrosão em aços inoxidáveis pode ocorrer sob diferentes formas considerando-se a sua aparência ou forma de ataque [19,20,24].

\section{3.1 - Corrosão generalizada ou uniforme}

É o termo usado para descrever um ataque uniforme sobre a superfície do metal com conseqüente diminuição da sua espessura. Essa forma de corrosão, do ponto de vista técnico, não envolve muita preocupação, uma vez que a vida dos equipamentos pode ser estimada, baseando-se em simples testes comparativos ou consultando tabelas de dados de perda de espessura por corrosão.

A elevada resistência à corrosão dos aços inoxidáveis é conferida por um filme de óxido de cromo que se forma em sua superfície, que tem características como boa aderência, alta resistividade elétrica, pouca porosidade, o que o torna uma camada protetora em meios oxidantes. A corrosão generalizada dos aços inoxidáveis é resultado da ruptura uniforme do filme passivo sobre a superfície exposta. A Figura 1 mostra dois esquemas de corrosão uniforme. 

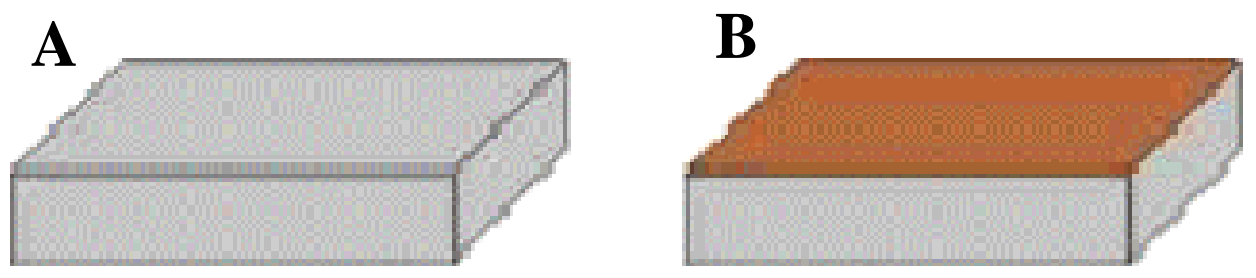

Figura 1 - (A) Chapa sem corrosão e (B) chapa com corrosão uniforme.

\section{3.2 - Corrosão intergranular}

Um fenômeno que pode contribuir para a corrosão em aços inoxidáveis é a sensitização. Alguns desses aços inoxidáveis, quando aquecidos em um intervalo de temperatura entre 450 e $950^{\circ} \mathrm{C}$, faz com que átomos de cromo e carbono se combinem formando 0 carboneto de cromo $\left(\mathrm{Cr}_{23} \mathrm{C}_{6}\right)$, que se precipita preferencialmente nos contornos de grãos. A conseqüência da sensitização é o empobrecimento de átomos de cromo nas regiões próximas aos contornos de grãos, podendo ficar com até $2 \%$ de cromo a menos. Essas regiões descromatizadas deixam de ser resistentes em determinados meios, ficando assim suscetíveis a ataques localizados nesses contornos de grãos. A Figura 2 ilustra um esquema de corrosão intergranular.
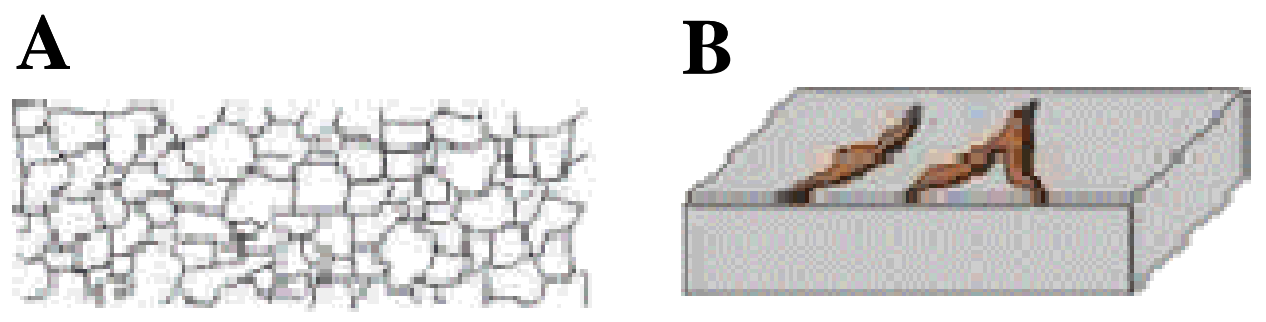

Figura 2 - (A) Micrografia de uma chapa com corrosão intergranular e (B) Vista da área exposta de um chapa com corrosão intergranular.

\section{3.3 - Corrosão puntiforme (pite)}

Este tipo de corrosão ocorre nos aços inoxidáveis quando estes são expostos a determinados meios que contenham cloretos. A principal causa da corrosão por pites é a ruptura local do filme passivo. Além disso, a limpeza da superfície do material 
também é um fator importante. Se houver um produto de corrosão ou algum tipo de depósito sobre a superfície metálica, essa região pode impedir o acesso de oxigênio, que é o agente principal da manutenção da camada de óxido que confere resistência à corrosão dos aços inoxidáveis $[24,25]$. Os pites geralmente crescem na direção da gravidade, como mostrado na Figura 3, e sempre que iniciando, penetra no metal a uma taxa crescente.
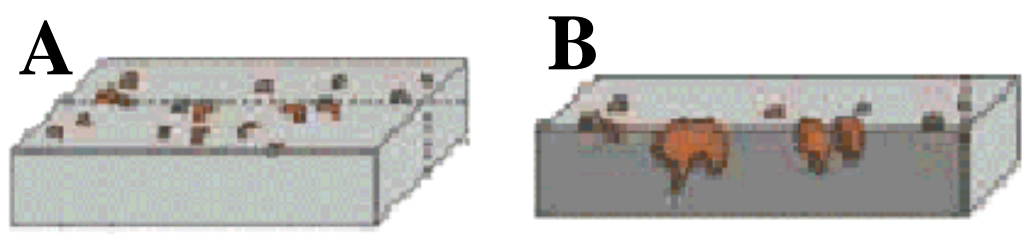

Figura 3 - Representação da corrosão por pites em um estagio intermediário: (A) vista superficial de uma chapa de aço inoxidável com corrosão por pite e (B) corte lateral de uma chapa de aço inoxidável com corrosão por pite.

A propagação do pite envolve dissolução e a manutenção de uma elevada acidificação no seu interior e subseqüente hidrólise dos íns metálicos dissolvidos. A reação de oxidação do metal no interior do pite é balanceada por uma reação de redução que ocorre na superfície adjacente, de acordo com:

$$
\begin{gathered}
\text { Reação de oxidação: } \mathrm{M}^{0} \rightarrow \mathrm{M}^{2+}+\text { ze } \\
\text { Reação de redução: } \mathrm{O}_{2}+2 \mathrm{H}_{2} \mathrm{O}+4 \mathrm{e}^{-} \rightarrow 4 \mathrm{OH}^{-}
\end{gathered}
$$

$\mathrm{O}$ aumento da concentração de $\mathrm{M}^{2+}$ no interior do pite resulta na migração de íons $\mathrm{Cl}^{-}$a fim de que seja mantida a eletroneutralidade. O composto formado, $\mathrm{MCl}_{z}$, é hidrolisado com a formação de um ácido livre e a precipitação de um hidróxido:

$$
\mathrm{MCl}_{\mathrm{z}}+\mathrm{zH}_{2} \mathrm{O} \rightarrow \mathrm{M}(\mathrm{OH})_{\mathrm{z}}+\mathrm{zH}^{+}+\mathrm{zCl}^{-}
$$

A geração deste ácido promove uma acidificação localizada (intervalo de $\mathrm{pH}$ : 1,0 e 1,5) estimulando a dissolução do metal. O efeito do crescimento do pite no 
sentido da gravidade mencionado anteriormente é resultado direto da natureza autocatalítica do pite, uma vez que o aumento da acidez no interior do pite é necessário para acelerar o processo corrosivo [20].

Estudar a corrosão tem importância fundamental, pois um material selecionado inadequadamente para uma determinada aplicação pode apresentar sérios problemas. Esses podem ser tantos fatores econômicos, pois existe a necessidade de substituir o metal destruído, implicando em gastos de reservas mundiais de minérios, mão de obra e energia para o processamento. Outro ponto a se salientar é o fator social, onde a corrosão pode ocasionar a contaminação de produtos e do ambiente, acidentes navais e automobilísticos, falhas mecânicas em aeronaves, desabamento de edifícios e pontes, vazamentos em tubulações de gasodutos e usinas nucleares, etc.

\section{4 - Proteção contra a corrosão}

Tendo conhecimento dos aspectos teóricos dos diferentes casos de corrosão, além dos estudos dos possíveis mecanismos para explicar os processos corrosivos, procura-se neste tópico mostrar os meios de proteção mais utilizados para minimizar cada caso de corrosão. O conhecimento dos mecanismos das reações envolvidas nos processos corrosivos é pré-requisito para um controle efetivo destas reações.

Os métodos práticos, adotados para diminuir a taxa de corrosão dos materiais metálicos podem ser esquematizados da seguinte forma [26]:

- Método baseado na modificação do processo: Este método leva em conta o projeto de estrutura metálica, as condições da superfície do metal e a aplicação da proteção catódica.

- Método baseado na modificação do meio corrosivo: As variáveis em que este método se baseia são a deareção da água ou solução neutra, purificação ou diminuição da umidade do ar e a adição de inibidores de corrosão.

- Método baseado na modificação do metal: Para esta metodologia pode se utilizar o tratamento térmico dos metais, adição de elementos de liga e o aumento da pureza do metal ou da liga.

- Método baseado nos revestimentos protetores: Este método tem como base utilizar revestimentos com produtos de reação (tratamento químico ou eletroquímico 
da superfície metálica), a utilização de revestimentos inorgânicos (cimentos e esmaltes) e os revestimentos orgânicos (tintas, resinas, polímeros, etc).

Destas metodologias acima citadas, as mais comumente utilizadas, para eliminar ou minimizar os efeitos da corrosão são: proteção anódica, catódica, inibidores de corrosão e o emprego dos revestimentos orgânicos e inorgânicos.

Em todos esses métodos utilizados, o fator econômico é primordial. Qualquer medida de proteção contra a corrosão será vantajosa economicamente se o custo da manutenção for baixo e os resultados eficientes. Então é necessário fazer um balanço econômico, para se poder julgar a vantagem das medidas de proteção recomendadas ou buscar novas formas eficientes de proteção contra a corrosão, onde o custo e a eficiência destas novas tecnologias tem que ser viáveis.

Uma alternativa que vem demonstrando ser promissora para a proteção contra a corrosão de aços inoxidáveis é o uso de recobrimento a base de polímeros condutores. Estes podem ser os únicos constituintes destas películas, ou então um dos componentes parciais como, por exemplo, uma mistura polimérica (blendas ou compósitos). A utilização destas películas baseadas em polímeros condutores se deve a condutividade destes materiais, que varia de $10^{-11}$ a $10^{5} \mathrm{Scm}^{-1}$ e também pelas características redox destes materiais [28].

\section{5 - Polímeros condutores}

Os primeiros relatos da obtenção dos polímeros condutores, foi a partir da observação quando, o poliacetileno na forma isolante foi exposto a agentes oxidantes ou redutores (substância dopante) provocavam um aumento na condutividade do poliacetileno de $10^{-8}$ a $10^{3} \mathrm{~S} \mathrm{~cm}^{-1}$ [28]. Sendo este o marco da descoberta dos polímeros condutores. Portanto, polímeros que são isolantes ou semicondutores quando sintetizados mediante a oxidação ou redução química ou eletroquímica, podem ser convertidos em polímeros que apresentam condutividade elétrica de um metal $[29,30]$.

Todos polímeros condutores são polímeros conjugados. Estes polímeros possuem um sistema de ligações simples e duplas alternadas ao longo da cadeia polimérica (elétrons $\pi$ conjugado estendido) [28], que pode ser modificado por processo químico ou eletroquímico denominado dopagem. A dopagem envolve a 
oxidação (retirada de elétrons) ou redução (adição de elétrons) à cadeia polimérica [29,30]. O polipirrol, politiofeno, derivados do politiofeno e as polianilinas (PAni) são exemplos de polímeros conjugados, podendo ser denominados de polímeros condutores $[28,29,30]$.

A característica principal de cada polímero é o sistema de elétrons $\pi$ conjugado estendido, assim, quando uma carga é deslocada neste sistema de um polímero eletronicamente condutor, esta conjugação torna possível o movimento de carga (na presença de um campo elétrico), fazendo com que apareça às propriedades metálicas [10].

Os polímeros condutores apresentam um grande numero de portadores de carga $\left(10^{21}\right.$ a $10^{23}$ portadores $\left./ \mathrm{cm}^{3}\right)$, mas com baixíssima mobilidade $\left(10^{-4}\right.$ a $10^{-5} \mathrm{~cm}^{2}$ $\mathrm{V}^{-1} \mathrm{~S}^{-1}$ ) devido principalmente ao grande número de defeitos estruturais (reticulação e desordenamento de cadeias). Desta forma, a obtenção de polímeros condutores com elevada condutividade está diretamente relacionada com o aumento da mobilidade dos portadores de carga. Isto pode ser viabilizado através da obtenção de materiais mais ordenados, ou seja, com melhor orientação das cadeias, livre de reticulações e defeitos estruturais [31].

A síntese de polímeros condutores pode ser realizadas por via química e eletroquímica [28,29,32,33]. O método de síntese tem uma forte influência na qualidade e propriedades finais do polímero. A seleção do método de polimerização está relacionada com a aplicação a ser feita do polímero condutor sendo estes aplicados em diversas áreas tecnológicas como: baterias, eletrocatálise, sensores, proteção à corrosão, capacitores eletrolíticos, janelas inteligentes, etc. [28, 33-35].

As películas protetoras baseadas em polímeros protetores podem ser produzidas na forma de filmes eletrodepositados sobre um substrato metálico ou formados pela solubilização de polímeros condutores em solventes apropriados e aplicados sobre a superfície do metal para a formação do filme [36].

Uma das características importantes de usar polímeros condutores como camadas protetoras, é o potencial de redução para seu par redox. No caso específico da PAni, este potencial é positivo em relação ao do alumínio, ferro e cromo [37]. Isto indica que a PAni é um polímero condutor que pode oferecer papel protetor na corrosão de metais ativos e com ligas destes metais. 


\section{6 - Polianilina}

Dentre as classes dos polímeros condutores, as polianilinas (PAni) tem tido destaque, pois possui distintas propriedades físicas e químicas $[30,32,38]$. O termo polianilina se refere a uma família de polímeros que possuem mais de 1000 unidades repetitivas de $p$-fenilenoimina [28,39]. A PAni existe em vários estados de oxidação e a condutividade elétrica varia de $10^{-11}$ a $10 \mathrm{Scm}^{-1}[28,40]$.

A composição química básica da PAni pode ser observada no esquema $(A)$ da Figura 4. Onde y corresponde a fração de unidades repetitivas reduzidas (benzóide) e 1-y a fração de unidades oxidadas (quinóides).

$\mathrm{O}$ valor de y pode variar continuamente entre 0 e 1 . Quando y assume o valor 1, o polímero está completamente reduzido e apresentando apenas nitrogênio da amina. Esta forma é conhecida como leucoesmeraldina sendo uma forma isolante (estrutura B). Quando y assume o valor zero, o polímero obtido se apresenta completamente oxidado contendo apenas nitrogênio da imina, também é uma forma isolante denominada pernigranina (estrutura C). A pernigranina pode ser protonada e formar o respectivo sal básico, sendo que este apresenta baixa condutividade.

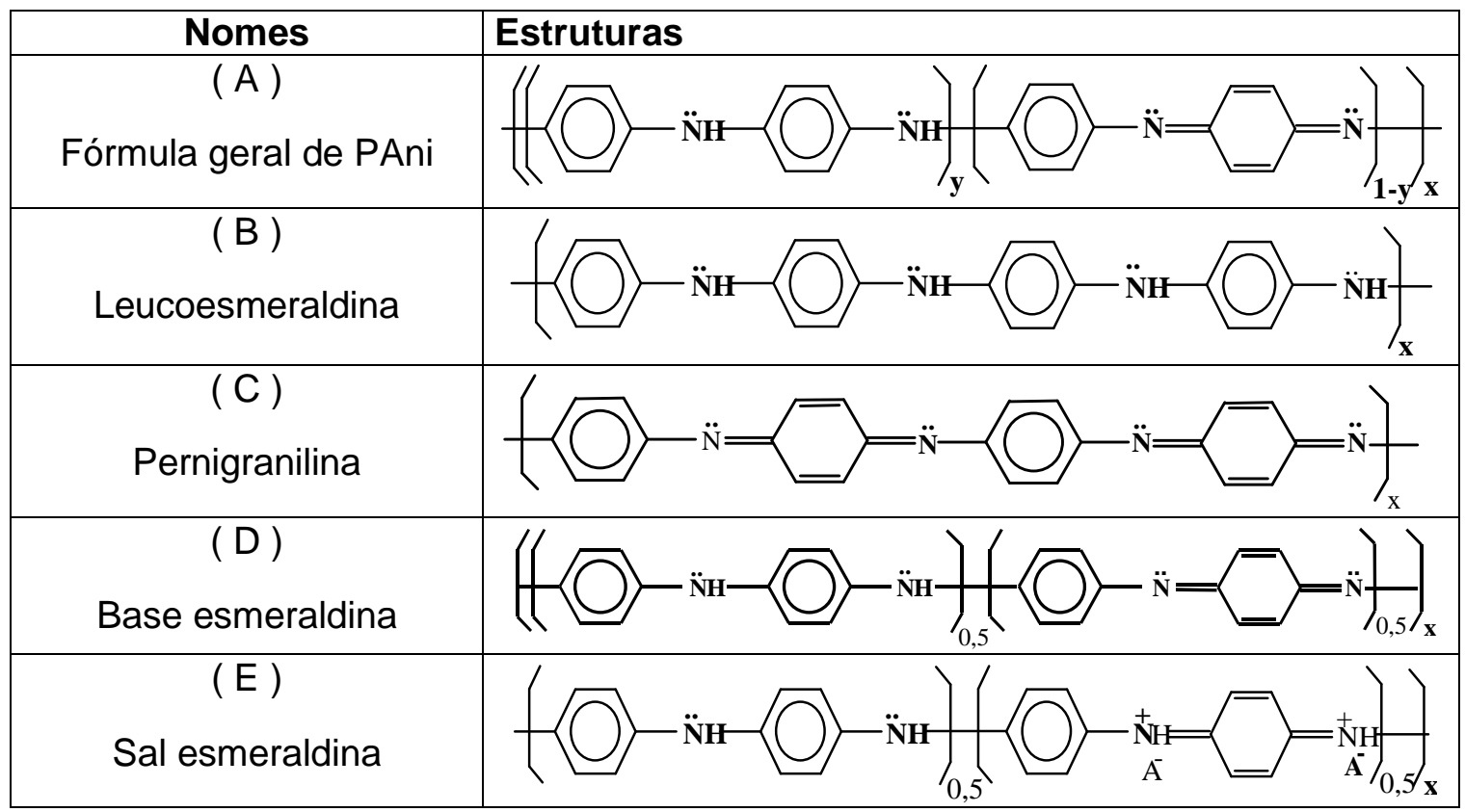

Figura 4 - Representação estrutural dos diferentes estados de oxidação da polianilina. 
Para $\mathrm{y}=0,5$, o polímero formado possui quantidades iguais de grupos oxidados (iminas) e grupos reduzidos (aminas), esta forma de PAni é conhecida como base esmeraldina (estrutura D) sendo um isolante. Quando a base esmeraldina está na presença de um doador de prótons, geralmente ácidos fortes, ela é protonada, (ocorrendo à oxidação interna do átomo de nitrogênio), preferencialmente nos grupamentos iminas. A base esmeraldina protonada é conhecida como sal de esmeraldina (estrutura E) sendo a forma mais condutora da PAni.

\section{6.1 - Síntese da PAni}

A polimerização oxidativa da anilina para a obtenção de PAni via síntese química requer um agente oxidante. Dentre os agentes oxidantes o persulfato de amônio, $\left(\mathrm{NH}_{4}\right)_{2} \mathrm{~S}_{2} \mathrm{O}_{8}$, é o mais utilizado, pois produz um polímero de melhor qualidade do que os agentes oxidantes contendo íons metálicos [32,38].

Eletroquimicamente a PAni é obtida utilizando técnicas galvanostáticas, potenciostáticas e potenciodinâmicas. Um meio aquoso ácido com pH entre 0 e 3, é necessário para ambas às vias de síntese (química e eletroquímica), enquanto a concentração de monômero pode variar de 0,01 a $2 \mathrm{~mol} \mathrm{~L}^{-1}$.

Um aspecto importante a síntese da PAni é a constante de dissociação ácida $\left(\mathrm{pK}_{\mathrm{a}}\right)$ do ácido. Na protonação de Pani está envolvida um equilíbrio, exclusivamente do segmento quinona, diamina, envolvendo dois nitrogênios imina com $\mathrm{pK}_{\mathrm{a} 1}=1,05 \mathrm{e}$ $\mathrm{pK}_{\mathrm{a} 2}=2,55$. Portanto, qualquer ácido cujo valor de $\mathrm{pK}_{\mathrm{a}}$ esteja dentro desta variação pode ser utilizado como dopante.

O polímero de anilina durante a síntese apresenta variação de coloração de amarelo, verde e azul intenso, correspondente aos estados de oxidação que o polímero assume $[32,41,42]$. O polímero obtido tanto pela via química quanto pela via eletroquímica encontra-se dopado $(50 \%$ de todos os átomos de nitrogênio do polímero protonado, independente de serem amina ou imina). O polímero sólido de cor verde escura, insolúvel em água e que se encontra na forma dopada, pode ser desdopado em presença de uma base fraca, tal como, hidróxido de amônio $[32,38,41]$. 
$\mathrm{Na}$ protonação da PAni não ocorre alteração do número de elétrons associados à cadeia polimérica. Os átomos de nitrogênio da estrutura podem estar totalmente ou parcialmente protonados e as cargas geradas são neutralizadas pelo ânion do ácido usado (dopante), assim o polímero encontra-se na forma de um sal (forma dopada). A PAni pode sofrer um processo de dopagem por transferência de carga, no qual ocorre a variação do número de elétrons na cadeia polimérica. $A$ carga gerada pelos cátions (tipicamente bipolarons) é compensada pelos contra-ions do dopante [43].

\section{6.2 - Síntese eletroquímica de PAni}

A voltametria cíclica é a técnica mais indicada para sintetizar polímeros mais homogêneos, com melhores propriedades condutoras, alem de elucidar os mecanismos redox do crescimento do polímero [44].

Segundo Diaz et al. [45] a PAni formada à potenciais constantes apresenta baixa aderência sobre a superfície do eletrodo. Entretanto, filmes de polianilina, formados por contínuos ciclos de potencial, proporcionam filmes que aderem fortemente à superfície do eletrodo, resultando em um polímero eletroativo com propriedades eletrocrômicas reversíveis. A qualidade e propriedades dos filmes crescidos por técnicas eletroquímicas dependem e são influenciadas, por vários parâmetros como: densidade de corrente, velocidade de varredura, intervalo de potenciais e tempo de deposição.

Especificamente, as propriedades físicas e cinéticas de eletropolimerização dependem de parâmetros como: temperatura, natureza do eletrólito, concentração do monômero e do pH do meio $[46,47,48]$.

Stiwell et al. [46] concluíram que os processos de crescimento dos filmes de PAni é um processo autocatalítico. Foi observado que a velocidade de crescimento do filme de polianilina é dependente da concentração do monômero em solução e do número de ciclos de potenciais. Após a reação de polimerização iniciar, as espécies de anilina oxidada se depositam sobre o eletrodo. Concomitantemente, o filme de PAni formado, também se oxida, catalisando as reações seguintes. Assim o crescimento de PAni se dá a potenciais mais baixos do que o potencial de oxidação da anilina. 
Um grande número de estudos sobre PAni tem mostrado que sua síntese é influenciada pela composição da solução [46,49]. Assim diversos tipos de ácidos [30,38,50-53] tem sido utilizados na síntese eletroquímica da PAni, tais como os ácidos: sulfônico, sulfâmico, oxálico, malônico, acético, etc.

Durante a deposição do polímero, a degradação e o crescimento dos filmes estão competindo para a formação de um intermediário comum, a partir da oxidação da PAni no estado dicatiônico (bipolarons). Como a anilina é um nucleófilo mais forte que a água, o filme freqüentemente cresce e domina a hidrólise, conduzindo ao crescimento autocatalítico do polímero [54-56]

Portanto a velocidade de formação da área ativa do polímero pode diminuir ou aumentar com o tempo de eletrossíntese, sendo esta função da composição do eletrólito, das condições de preparação e da espessura do filme [57].

\section{6.3 - Polianilina como agente protetor contra a corrosão}

Recentemente, tem havido um crescente interesse no uso de polímeros eletroativos no controle da corrosão por pite, resultante da permeação ou deterioração da camada protetora $[10,58]$. Os polímeros servem como um mediador da corrente anódica entre a camada passiva e a redução de oxigênio no filme polimérico.

O uso de filmes de polianilina como agente protetor conta à corrosão de metais, em particular superfícies de aços, foi relatada por De Berry [58]. Neste caso, a PAni foi depositada eletroquimicamente sobre aço inoxidável ferrítico. O filme promove uma proteção anódica que reduz a velocidade de corrosão em soluções ácidas. A deposição eletroquímica de PAni foi precedida pela formação de uma camada passiva de óxido na superfície do aço. A camada d PAni em contato com o aço estabiliza as reações de dissolução e reduz o processo de corrosão.

A maioria dos estudos de corrosão tem sido realizados, utilizando meios aquosos contendo $\mathrm{HCl}$ e $\mathrm{H}_{2} \mathrm{SO}_{4}$. Esses ácidos, em contato com o metal iniciam o processo de corrosão devido à formação de cloretos e sulfatos, que servem de substratos para o polímero ser depositado. Alguns autores [59-62], observam que para a aplicação industrial, o depósito de polímero sobre o aço deve ser acompanhado de um processo de proteção contra a corrosão, tal qual a 
fosfatização, no qual o meio ácido possui elevada concentração de íons fosfato que tende a melhorar a resistência do filme e passivar o metal $[61,63,64]$. Esta melhoria é atribuída à camada passiva que cresce sobre o ferro. Esta camada é formada por um material polimérico coloidal constituído de oxi-hidróxidos de ferro e fosfato. Essa camada apresenta boa resistência à corrosão e boa condutividade possibilitando a formação de PAni [59]. Outro meio é o de oxalato. A passivação neste caso ocorre por precipitação de uma fina camada de oxalato de ferro, a qual inibe fortemente a dissolução do metal sem interferir nos processos eletroquímicos seguintes $[63,65,66,67]$.

Ahmad et al. [68] relatam que a polianilina no estado de oxidação esmeraldina possui um forte poder oxidativo para passivar o aço inoxidável. Santos-Junior et al. [69] demonstram a eficiência de Pani química desdopada e proteger o aço carbono e inoxidável da corrosão em meio cloreto. Neste caso, a eficiência de PAni em proteger metais contra a corrosão foi constatada mesmos após os aços recobertos ficarem expostos ao ar por um mês.

Em geral, PAni desdopada tende a apresentar melhor resultado como cobertura resistente à corrosão do que a PAni dopada [10,62]. Esses resultados são atribuídos à formação de um eficiente filme formado sobre a superfície do ferro. Isto foi determinado por Espectroscopia Fotoelétrica de Raio-X e também constatado por um aumento do potencial de corrosão para valores mais positivos, além da diminuição da taxa e da corrente de corrosão.

Dois métodos clássicos de proteção contra a corrosão são comumente associados ao efeito barreira e proteção por inibição.

Em um outro relato em literatura [70] verificou que o mecanismo de proteção exercido pela PAni é considerado um efeito barreira e inibição eletroquímica. $O$ transporte de substâncias voláteis (incluindo oxigênio) através do filme de PAni eletrodepositado sobre aço, mostra que o coeficiente de permeação do oxigênio é dependente do estado de oxidação da PAni, ou seja a permeação diminui com o aumento da dopagem.

Claramente, percebe-se que o recobrimento de um metal com um polímero condutor produzirá algum tipo de efeito barreira. Desta forma, foi verificado que um filme de PAni eletropolimerizada sobre ferro diminuía a taxa de corrosão. Esta 
diminuição da corrosão foi atribuída somente ao efeito barreira, onde as interações eletroquímicas são consideradas insignificantes. 


\section{Capítulo II}

\section{Objetivos}

O presente trabalho tem como objetivo geral sintetizar, caracterizar, propor um mecanismo de deposição de um filme de PAni sobre os diferentes aços inoxidáveis e analisar a potencialidade dos filmes de PAni como agentes protetores contra a corrosão. As metas que constituíram este estudo foram:

(a) Polimerização eletroquímica dos filmes de PAni, em meio de ácido oxálico, sobre os aços inoxidáveis do tipo AISI 304, AISI 430 e AISI 420.

(b) Determinação das características dos materiais poliméricos resultantes pelas técnicas: espectroscopia no UV-vis-NIR e no infravermelho, morfologia por MEV e resposta eletroquímica.

(c) Proposição do mecanismo de deposição do filme de PAni sobre os diversos aços. Para isto, foi analisado o comportamento das cargas anódicas totais nos estágios iniciais de nucleação, relação entre a variação de carga e a velocidade de varredura $\mathrm{e}$, análise do comportamento da carga anódica total na resposta eletroquímica dos aços em ácido oxálico, na ausência de anilina. Estudo do comportamento do filme de PAni utilizando a espectroscopia de impedância eletroquímica (EIS) e por difração de raios $\mathrm{X}$.

(d) Análise da viabilidade de uso dos filmes de PAni como revestimento dos aços inoxidáveis, para a proteção contra a corrosão, realizando estudos de polarização potenciodinâmica, para determinar o sistema com maior eficiência em meio contendo $\mathrm{NaCl} 3 \%$. 


\section{Capítulo III}

\section{Experimental}

Neste capitulo são descritos os procedimentos práticos utilizados para o desenvolvimento deste trabalho. Assim, descreve-se a construção e tratamento prévio dos eletrodos, reagentes e soluções, caracterização dos aços inoxidáveis a serem estudados assim como, o procedimento para sintetizar eletroquimicamente PAni. São descritos também procedimentos experimentais utilizados para caracterização do material polimérico, ensaios de corrosão com os polímeros.

\section{1 - Construção e tratamento prévio dos eletrodos}

Os eletrodos, com $1,0 \mathrm{~cm}$ de diâmetro e $0,5 \mathrm{~cm}$ foram confeccionados a partir de chapas de aços inoxidáveis do tipo AISI 304, AISI 420 e AISI 430 de espessura. Os discos forma embutidos em resina metalográfica BUHLLER ${ }^{\circledR}$, sendo o contato elétrico constituído de um fio de cobre.

Os eletrodos de aços inoxidáveis foram polidos mecanicamente com lixa d'água com granulometrias variando de 220 a 1500, desengraxados com etanol e lavados abundantemente com água purificada.

A limpeza do contra eletrodo de platina foi realizada por exposição repetida a chama oxidante, e seguido de imersão em água a temperatura ambiente. Este

procedimento tem como finalidade limpar os eletrodos de resíduos de ácidos e substâncias orgânicas. Os eletrodos de calomelanos saturados (ECS) utilizado como 
referência foi limpo com sucessivas lavagens com água purificada a temperatura ambiente.

A célula eletroquímica e toda vidraria foram lavadas com soluções ácidas de permanganato de potássio $\left(\mathrm{KMnO}_{4}\right)$ e peróxido de hidrogênio $\left(\mathrm{H}_{2} \mathrm{O}_{2}\right)$, e enxágüe com água.

\section{2 - Reagentes e soluções}

A água utilizada para o preparo das soluções e limpeza de um sistema de purificação Milli-Q (Millipore).

Os reagentes utilizados para sintetizar eletroquimicamente PAni são descritos a seguir:

- A anilina $\left(\mathrm{C}_{6} \mathrm{H}_{5} \mathrm{NH}_{2}\right.$ - Mallinckrodt - 99,5\%) foi destilada sob pressão reduzida na presença de óxido de zinco em pó, conservada entre 0 e $4^{\circ} \mathrm{C}$, sob atmosfera de nitrogênio.

A solução empregada para sintetizar eletroquimicamente os polímeros foi.

- Ácido oxálico $\left(\mathrm{C}_{2} \mathrm{H}_{2} \mathrm{O}_{4} \cdot 2 \mathrm{H}_{2} \mathrm{O}\right.$ - Merck) $0,3 \mathrm{~mol} \mathrm{~L}^{-1}$ em presença de 0,1 mol $L^{-1}$ de anilina destilada.

Para o processo de desdopagem dos polímeros foi utilizado:

- Hidróxido de amônio ( $\mathrm{NH}_{4} \mathrm{OH}$ - Synth) 0,1 mol L-1.

Para a caracterização dos polímeros formados utilizou-se:

- Ácido oxálico $\left(\mathrm{C}_{2} \mathrm{H}_{2} \mathrm{O}_{4} \cdot 2 \mathrm{H}_{2} \mathrm{O}\right.$ - Merck) $0,3 \mathrm{~mol} \mathrm{~L}^{-1}$.

-1-metil-2-pirrolidona (NMP - Merck) como solvente nas análises por espectroscopia UV-vis-NIR.

Para os ensaios eletroquímicos de corrosão foi utilizado:

- Solução aquosa de cloreto de sódio ( $\mathrm{NaCl}$ - Merck) 3\%, usado como eletrólito nos ensaios de corrosão.

\section{3 - Célula Eletroquímica}

A célula eletroquímica usada na síntese eletroquímica e nos ensaios de corrosão consistiu em um copo cilíndrico de compartimento único, construído em vidro Pyrex ${ }^{\circledR}$ com uma tampa de Teflon ${ }^{\circledR}$ com múltiplas perfurações, nas quais foram acoplados os eletrodos, como mostrado na Figura 5. 


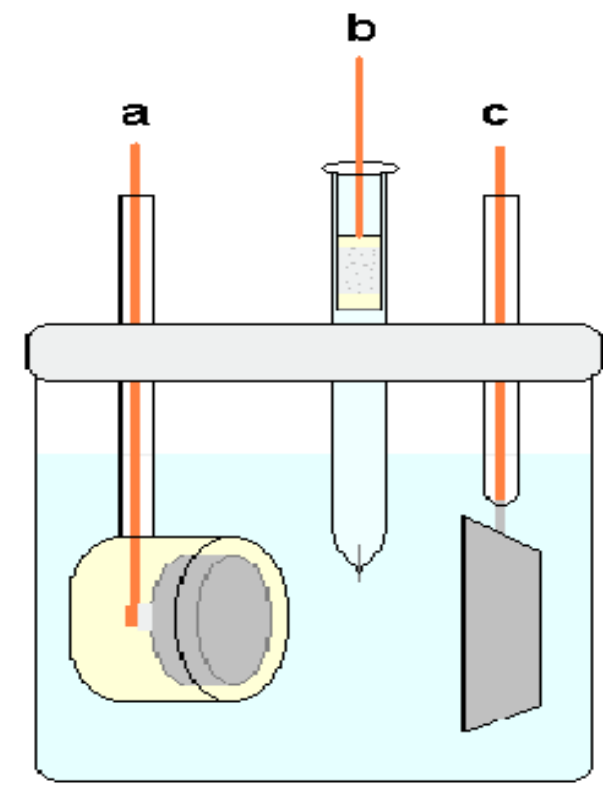

Figura 5 - Esquema da célula eletroquímica onde, (a) é o eletrodo de trabalho (chapa de aço inoxidável), (b) eletrodo de referência (ECS) e (c) contra eletrodo (chapa de platina).

\section{4 - Análise das composições nominais dos aços inoxidáveis}

As composições nominais dos aços AISI 304, AISI 420 e AISI 430 foram realizadas, utilizando a técnica de espectrometria de emissão ótica, regida pela norma ASTM - E 327 - 94 [71]. A Tabela II mostra as composições nominais obtidas dos aços estudados.

Tabela II - Composição nominal dos aços inoxidáveis em porcentagem de massa

Teores dos constituintes da liga em \%

\begin{tabular}{c|c|c|c|c|c|c|c|c}
\hline Classe & Tipo & C & Mn & Si & S & P & Cr & Ni \\
\hline Austeníticos & AISI 304 & 0,06 & 1,25 & 0,63 & 0,02 & 0,01 & 18,90 & 8,95 \\
\hline Martensíticos & AISI 420 & 0,19 & 0,88 & 0,32 & 0,01 & 0,02 & 12,55 & \\
\hline Ferríticos & AISI 430 & 0,10 & 0,58 & 0,41 & 0,01 & 0,01 & 17,10 & \\
\hline
\end{tabular}


Os resultados da análise das composições nominais dos aços inoxidáveis estão em concordância com os valores relatados na Tabela I do capítulo 1.

\section{5 - Ensaios de corrosão}

Os estudos de corrosão foram realizados utilizando a técnica de polarização potenciodinâmica, cuja finalidade é estabelecer os parâmetros eletroquímicos como: potencial de corrosão, corrente de corrosão, potencial de pite, assim como a velocidade de corrosão das amostras de aço inoxidável, com e sem recobrimento de PAni em solução de $\mathrm{NaCl} 3 \%$ aerada.

\section{5.1 - Polarização potenciodinâmica}

As curvas de polarização anódica consistem em uma lenta varredura linear de potenciais, partindo-se de um determinado valor negativo de potencial e seguindo para valores positivos. O comportamento corrosivo da maioria dos materiais pode ser investigado por este tipo de procedimento, onde se obtém valores referentes ao potencial de corrosão $\left(E_{\text {corr }}\right)$, potencial de pite $\left(E_{\text {pite }}\right)$, densidade de corrente de corrosão (i $\left.i_{\text {corr }}\right)$, resistência à polarização $\left(R_{p}\right)$ e taxa de corrosão $(T C)[72,73]$.

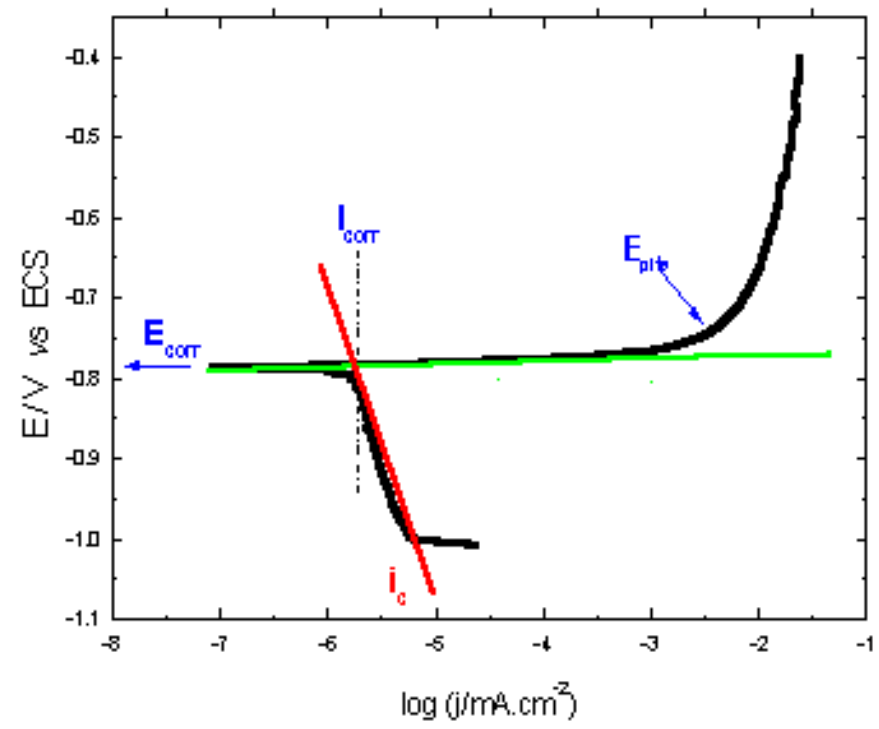

Figura 6 - Parâmetros de corrosão extraídos de uma curva de polarização anódica.

A obtenção dos parâmetros eletroquímicos pode ser realizada, pois há um 
potencial no qual é atingido um equilíbrio entre as reações catódicas e anódicas, este potencial é conhecido como potencial de corrosão ( $\left.E_{\text {corr }}\right)$, no qual, a taxa de oxidação do material é igual à taxa de redução. A partir deste potencial ocorre o processo de corrosão metálica [74]. A Figura 6 mostra um exemplo de curva potenciodinâmica. Nesta curva, a varredura inicia-se em valores negativos de potenciais até atingir o potencial de equilíbrio ( $\left.E_{\text {corr }}\right)$. Neste ponto, o potencial de corrosão se estabiliza, até atingir o potencial de pite $\left(E_{\text {pite }}\right)$, então o potencial se eleva para valores mais positivos, a densidade de corrente se estabiliza, evidenciando a passivação da superfície metálica. As retas tangentes (vermelho e verde), são conhecidas como as curvas de Tafel, através das extrapolações dessas curvas pode se obter os valores de potencial de corrosão e densidade de corrente de corrosão.

A equação abaixo é uma expressão matemática derivada da equação de Faraday que permite relacionar a densidade de corrente de corrosão (i $\left.\mathrm{i}_{\text {corr }}\right)$, com a taxa de corrosão (TC):

$$
\mathrm{TC}=\frac{\text { M.icorr }}{\mathrm{n} \cdot \mathrm{F}}
$$

Onde: $\underline{M}$ é a massa molar do metal, $\underline{n}$ é o numero de elétrons envolvidos na reação e F é a constante de Faraday.

Desta forma os aços inoxidáveis com e sem revestimento de PAni, foram submetidos a uma lenta varredura de potenciais $\left(0,5 \mathrm{mV} \mathrm{s}^{-1}\right)$ num intervalo de potenciais que variou de $-0,6$ a 0,3 V, em uma solução de $\mathrm{NaCl} 3 \%$ aerada. Esses ensaios foram realizados em um potenciostato/galvanostato da EG\&G/PAR modelo 273A, interfaciado a um microcomputador e gerenciado pelo software M352/252 (EG\&G/PAR)

\section{6 - Síntese eletroquímica de PAni}

\section{6.1 - Voltametria cíclica}

A cinética de processos eletródicos é comumente estudada por voltametria cíclica, técnica esta que envolve o monitoramento da corrente quando o potencial do 
eletrodo de trabalho é variado com o tempo. A Figura 7 (a) ilustra o voltamograma cíclico (VC), na qual o potencial é variado linearmente entre $E_{1}$ e $E_{2}$ e em seguida entre $E_{2}$ e $E_{1}$. A taxa de variação do potencial em relação ao tempo é conhecida como velocidade de varredura de potencial.

Um VC fornece indicações sobre a reversibilidade das reações de transferência de elétrons, precedidas ou seguidas por reações químicas, relativamente lentas e dos efeitos de adsorção [14,75]. A Figura 7 (b), mostra um voltamograma cíclico, onde pode ser observado que o potencial se aproxima do potencial de redução das espécies em solução, a corrente catódica aumenta. Logo após o potencial exceder ao potencial de redução, uma rápida variação na corrente acontece devido à elevada concentração das espécies oxidáveis nas proximidades do eletrodo. Quando o potencial se aproxima do potencial requerido para oxidar as espécies reduzidas, surge uma corrente substancial até que toda oxidação se complete, e a corrente retorne a zero [76]. Portanto, o sistema é examinado sob condições de não equilíbrio em um curto período de tempo.
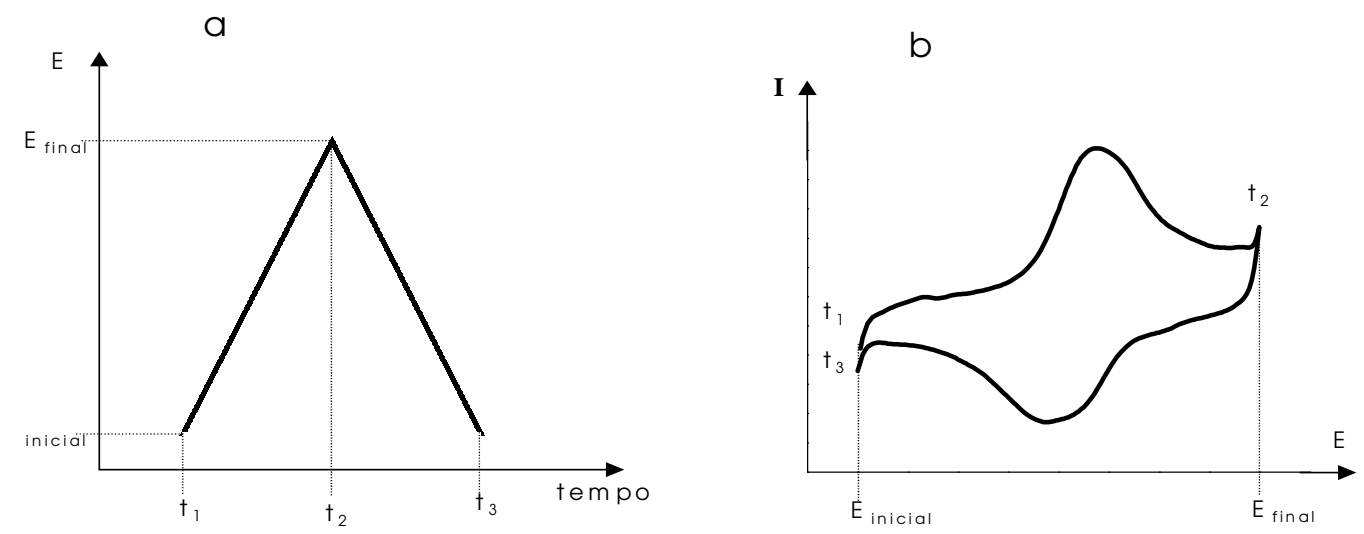

Figura 7 - (a) Variação do potencial com o tempo e (b) curva resultante da corrente por potencial em um voltamograma cíclico típico.

Entre as várias aplicações da técnica de voltametria cíclica, sua utilização nos estudos envolvendo polímeros condutores é de grande importância, fornecendo vários parâmetros relacionados aos estágios de crescimento, além de proporcionar um excelente controle sobre a qualidade dos polímeros [77]. 


\section{6.2 - Eletropolimerização de PAni, sobre os eletrodos de aços inoxidáveis.}

Após os eletrodos serem lixados e desengraxados, estes foram inseridos na célula eletroquímica, com conseqüente imersão em uma solução de $0,1 \mathrm{~mol} \mathrm{~L}^{-1}$ de anilina dissolvida em uma solução $0,3 \mathrm{~mol} \mathrm{~L}^{-1}$ de ácido oxálico.

O crescimento do filme de PAni na forma dopada sobre os eletrodos de aços inoxidáveis: AISI 304, AISI0420 e AISI 430, baseou-se nos estudos de Camalet et al. [69], com algumas modificações. A polimerização eletroquímica, utilizando a técnica de voltametria, sobre o aço inoxidável foi limitada em um máximo de 90 ciclos, sendo que estes ciclos foram divididos em 2 etapas a uma velocidade de varredura de potenciais de $50 \mathrm{mV} \mathrm{s}^{-1}$.

- Etapa $1-1$ ciclo no intervalo de potencial: $-0,6 \mathrm{a}+1,5 \mathrm{~V}$

- Etapa2 - 89 ciclos no intervalo de potenciais: $-0,2 \mathrm{a}+0,8 \mathrm{~V}$

$\mathrm{O}$ procedimento adotado foi o que resultou em filmes mais aderentes sobre o eletrodo. Isto foi verificado pelo teste "Sellotape", que consistiu em aderir uma fita adesiva (850 dA 3M) sobre a superfície do metal recoberta com o polímero e verificar sua adesão ou remoção do material da superfície.

O equipamento utilizado para aplicar a técnica de voltametria cíclica foi um potenciostato/galvanostato da EG\&G/PAR modelo 273A, acoplado a um microcomputador e gerenciado pelo software M270.

Os filmes de PAni na forma desdopada foram obtidos pela imersão dos eletrodos recobertos com PAni, em uma solução de $0,1 \mathrm{~mol} \mathrm{~L}^{-1}$ de $\mathrm{NH}_{4} \mathrm{OH}$ por 24 horas.

\section{7 - Caracterização do polímero}

\section{7.1 - Espectroscopia na região do ultravioleta- visível e infravermelho próximo (UV-Vis-NIR).}

A espectroscopia na região do ultravioleta $(200-400 \mathrm{~nm})$ e visível (400-750 $\mathrm{nm}$ ) permite visualizar o comportamento eletrônico de determinados materiais, uma vez que os níveis de energia empregados correspondem aos níveis de energia de 
excitação eletrônica do material. Esses níveis de excitação eletrônica são dependentes dos tipos de elétrons que formam as ligações químicas dos compostos (elétrons $\sigma$ absorvem fótons de elevadas energias, enquanto elétrons $\pi$ absorvem fótons de baixa energia).

A técnica analítica de espectroscopia de UV-Vis-NIR isoladamente não é capaz de identificar totalmente um composto desconhecido. Desta forma, limita-se a visualizar o comportamento eletrônico do polímero [78].

Nos espectros de PAni e seus derivados pode ser notado um comportamento de mudança na configuração eletrônica do polímero pela adição de ácidos, que são os agentes protonadores. Esta mudança é observada pela diminuição de bandas na região de alta energia (baixos comprimentos de onda) e deslocamentos de bandas em regiões de menores energias (comprimentos de ondas mais elevados) [75].

Para a realização dos estudos espectroscópicos nas regiões do UV-Vis-NIR, as amostras foram preparadas adotando o seguinte procedimento: (a) o polímero foi desprotonado na presença de solução de $\mathrm{NH}_{4} \mathrm{OH} 0,1$ mol L-1 (processo de desdopagem) durante 24 horas; (b) lavagem com água e secagem do polímero em um dessecador sob vácuo durante 48 horas; (c) dissolução do polímero em NMP. A dopagem do polímero foi realizada com o agente dopante $(\mathrm{HCl}$ 5,0 mol L-1), adicionando à solução (polímero mais NMP) minutos antes da análise.

Os espectros de UV-Vis-NIR dos polímeros foram obtidos em um equipamento da VARIAN CARY modelo 2315, utilizando-se cubetas de quartzo, com caminho óptico de $1 \mathrm{~cm}$ e NMP como solução de referência (branco).

\section{7.2 - Espectroscopia na região do infravermelho (IV)}

A espectroscopia na região do infravermelho é uma técnica de análise utilizada para melhor identificação de um composto, pois é capaz de fornecer informações detalhadas sobre a estrutura do polímero. A espectroscopia de infravermelho baseia-se nas transições entre níveis de energia das moléculas, que são resultados das vibrações das ligações químicas desta molécula, ou seja, como conseqüência da mudança de distribuição eletrônica nas ligações das moléculas, ocorre uma mudança no memento dipolar das ligações, resultando em vibrações moleculares diferentes. 
Por meio de interações com radiação eletromagnéticas apropriadas, ou seja, de comprimento de onda, energia suficiente relativo ao estado fundamental e o primeiro nível de energia vibracional excitado da molécula, é possível estimar a transição entre os níveis de energia vibracionais. Quando a interação ocorre, existe uma absorção da radiação pelo material e então a detecção é feita por diferença entra as intensidades de radiação emitida (inicial) e absorvida (final) na amostra. Desta forma, diversos grupos funcionais podem ser identificados através dos diferentes modos vibracionais das ligações químicas presentes.

Os polímeros de PAni foram sintetizados de forma análoga aos preparados para a análise de espectroscopia UV-Vis-NIR. As etapas de lavagem, desdopagem, e secagem dos polímeros foram realizadas como descrito na seção 3.51. Após estas etapas, o polímero foi triturado na presença de $\mathrm{KBr}$ para a confecção das pastilhas. Análises dos polímeros obtidos eletroquimicamente na sua forma dopada também foram realizadas.

Os espectros na região do infravermelho dos polímeros foram obtidos com um equipamento da BOMEN, modelo MB-102 com FTIR. Os dados forma obtidos com o auxílio do programa Spectra Calc.

\section{7.3 - Microscopia eletrônica de varredura (MEV)}

A microscopia eletrônica de varredura possibilita a formação de imagens pelo bombardeamento de elétrons em uma amostra. As imagens obtidas podem ter um aumento de até 300.000 vezes, com uma profundidade de $10 \mathrm{~nm}$ [79]. A formação da imagem se dá pela varredura sincronizada de um feixe de elétrons amostra e outro dentro do tubo de raios catódicos do monitor de vídeo. Isto é realizado na presença de um detector de elétrons secundários ou retroespalhados.

As amostras são alocadas em uma câmara de vácuo para que sejam realizadas as imagens. Portanto, é necessário que as amostras estejam secas, para que não ocorra evaporação dentro da câmara do aparelho. Além disso, é necessário que a amostra seja condutora de elétrons, pois o bombardeamento de elétrons torna a amostra carregada e esta corrente depositada sobre a amostra deve ser alternada. Para a realização das imagens de amostras não condutoras é necessário que estas 
tenham sua superfície recoberta por uma fina camada de substância condutora, como por exemplo, ouro. Este processo é conhecido como sputerring.

O equipamento utilizado para a obtenção das imagens de microscopia eletrônica foi um microscópio eletrônico de varredura LEO Cambridge, modelo 440.

Como as amostras não são condutoras, estas foram recobertas com ouro para se obter uma melhor resolução das micrografias. Foram realizadas microscopias dos aços inoxidáveis após o polimento superficial e após os ensaios de corrosão, cuja finalidade de visualizar os diversos tipos de corrosão. Foram realizadas também microscopias dos eletrodos recobertos com os filmes dopados e desdopado, antes e depois dos ensaios de corrosão.

\section{8 - Comparação da eletropolimerização de PAni sobre os aços inoxidáveis.}

Este estudo teve como finalidade diferenciar a deposição dos filmes de PAni, sobre aços inoxidáveis que possuem microestruturas e constituições nominais diferentes. Para isto, foram utilizadas as seguintes técnicas: voltametria cíclica, espectroscopia de impedância eletroquímica e espectroscopia de difração de raios $\mathrm{X}$.

\section{8.1 - Resposta eletroquímica}

Os aços inoxidáveis foram submetidos a três estudos utilizando a técnica de voltametria cíclica, onde se faz uma comparação do crescimento do polímero, da formação de uma camada de oxalato sobre esses aços e dos estágios iniciais de polimerização. Estes estudos têm como finalidade elucidar as diferenças na deposição do filme de PAni sobre os aços estudados.

No primeiro estudo, relacionou-se a carga do pico anódico ( $250 \mathrm{mV}$ ), referente à oxidação do polímero, com os 90 de ciclos da eletropolimerização.

No segundo estudo, os eletrodos de aço inoxidável sem recobrimento do filme de PAni, foram submetidos a 1 ciclo num intervalo de potencial de $-0,6$ a 1,8 V, com uma velocidade de varredura de $50 \mathrm{mV} \mathrm{s}^{-1}$, em uma solução de $0,1 \mathrm{~mol} \mathrm{~L}^{-1}$ de anilina em meio de ácido oxálico. Então, relacionou-se a carga total de ramo anódico (referente aos estágios iniciais de nucleação do filme de PAni sobre o substrato metálico) com os aços inoxidáveis estudados. 
No terceiro estudo, os eletrodos de aço inoxidáveis sem recobrimento foram submetidos a varreduras a 10 ciclos num intervalo de potencial que variou de $-0,2$ a $+0,8 \mathrm{~V}$, com uma velocidade de varredura de potenciais de $50 \mathrm{mV} \mathrm{s}^{-1}$, em uma solução de ácido oxálico $0,3 \mathrm{~mol} \mathrm{~L}^{-1}$. Da mesma forma, visando uma relação entre a formação de um filme de oxalato sobre os diversos aços, calculou-se a carga total do ramo anódico para os três aços inoxidáveis: AISI 304, AISI 420 e AISI 430.

\section{8.2 - Espectroscopia de impedância eletroquímica (EIS)}

O conceito de resistência elétrica pode ser definido pela lei de Ohm, onde resistência é a forma de um circuito resistir a um fluxo de corrente e pode ser matematicamente expresso por:

$$
\mathrm{R}=\mathrm{V} / \mathrm{I}
$$

Onde $\mathrm{R}$ é a resistência expressa em ohms, $\mathrm{V}$ é voltagem em volts e I é a corrente em amperes. Entretanto, esta relação é limitada a um circuito elementar, o resistor. No mundo real, alguns sistemas complexos são forçados a abandonar o simples conceito de resistência [80]. Para isto lança-se mão de usar um conceito mais elaborado chamado de impedância, $Z$, cuja função é medir a tendência de um sistema resistir, ou impedir o fluxo de corrente elétrica alternada (ac). A expressão matemática equivalente pode ser descrita como:

$$
\mathrm{Z}=\mathrm{V}_{\mathrm{as}} / \mathrm{l}_{\mathrm{ac}}
$$

$\mathrm{Na}$ EIS, uma corrente alternada de freqüência variável é aplicada a amostra, sendo a freqüência alta para reações rápidas e baixa para reações lentas. Isto permite que um espectro de impedância acumule uma grande quantidade de informações eletroquímicas em um único experimento.

A espectroscopia de impedância eletroquímica pode quantitativamente medir tanto a resistência de um material, quanto sua capacitância em uma célula eletroquímica. Para substâncias orgânicas usadas como recobrimento, as medidas de capacitância feitas pela EIS podem ser esclarecedoras, como por exemplo, o recobrimento orgânico deteriora-se com o tempo, quando exposto a um eletrólito e a EIS pode mostrar mudanças tanto na capacitância quanto na resistência dessa 
camada nesse intervalo de tempo. Além disso, pode ser mensurada a capacitância e a resistência de um filme quando houver mudanças na porosidade deste filme. A EIS permite também monitorar simultaneamente a taxa de corrosão de um substrato metálico, quando este está exposto ao eletrólito ou quando o eletrólito permeia por falhas no recobrimento. Neste trabalho, o uso da EIS teve como finalidade verificar como a dependência da formação do filme de PAni e da camada de oxalato sobre o substrato metálico, com as diferentes microestruturas e composições dos aços inoxidáveis estudados, evidenciando assim um mecanismo de crescimento diferente do polímero para cada aço.

Para as medidas de EIS, foi utilizados um potenciostato/galvanostato Autolab PGSTAT 30, com módulo de impedância FRA2. Essas medidas forma feitas nos eletrodos de aços inoxidáveis sem recobrimento, com recobrimento de PAni e com recobrimento de uma camada de oxalato metálico, foram submetidos à técnica de EIS realizada a potencial fixo, em uma solução de $\mathrm{NaCl} 3 \%$, com a freqüência variando de $10^{5}$ a $10^{-2} \mathrm{~Hz}$.

\section{8.3 - Difração de Raio X}

A difração de raios-X pelos cristais é importante e muito utilizada para informações sobre as posições relativas dos átomos em um sólido. Desta forma a difração contribui para a compreensão da estrutura molecular de um sólido, e de suas características físico-químicas [81].

A difração se dá quando duas ou mais ondas eletromagnéticas de alta freqüência (raios-X) encontram planos atômicos. Os átomos dos planos atômicos difratam o raio incidente em ângulos bastante definidos $(\theta)$, chamados de ângulos de difração, que dependem do comprimento de onda do raio incidente e da distância interplanar.

A detecção dos raios-X difratados pode ser feita por telas fluorescentes, filmes fotográficos ou detectores eletrônicos. Em câmaras são usados filmes fotográficos, mas o enorme avanço da tecnologia eletrônica permitiu o desenvolvimento de poderosos e úteis equipamentos com detectores eletrônicos.

No difratômetro uma amostra é exposta a radiação monocromática (produzida por um tubo de raios- $X$ e filtrada), e o registro da intensidade da difração nos diferentes 
ângulos é feita por um detector. Após a detecção das intensidades nos diferentes ângulos, os dados são registrados na forma gráfica denominada difratograma. Um difratograma apresenta picos referentes a máximos de intensidades em determinados ângulos. Estes picos são correspondentes à difração dos raios-X por planos (hkl) paralelos, onde a intensidade de um pico pode ser relacionada com a concentração de um componente de uma mistura.

Os aços inoxidáveis recobertos com um fino filme de PAni foram submetidos à análise por difração de raios-X, realizados no difratômetro URD-6 utilizando-se radiação de cobre (50 kV / $100 \mathrm{~mA}$ ), com ângulo de incidência variando 5 a 100 .

As análises dos difratogramas das amostras foram feitas por comparação com os padrões do banco de dados do JCPDS (Joint Comitee of Powder Diffraction Standard). 


\section{Capítulo IV \\ Resultados e Discussão}

Neste capitulo são descritos as seções referentes aos resultados obtidos para a síntese e caracterização do filme de PAni sobre os aços inoxidáveis. A proposição do mecanismo de formação do filme de PAni, sobre os aços inoxidáveis, foi analisada a partir do comportamento das cargas anódica totais, observadas nos processos de processos de nucleação e crescimento do filme, aliada a espectroscopia de difração de raios $\mathrm{X}$ e espectroscopia de impedância.

Em outra seção são descritos os ensaios de corrosão para os aços recobertos com filme de PAni nos estados dopados e desdopados. O comportamento corrosivo, destes aços com revestimento, foi estudado por curvas de polarização potenciodinâmicas e os resultados obtidos para os aços com revestimento foram comparados com os resultados obtidos para os aços sem revestimento.

\section{1 - Síntese e caracterização de PAni eletropolimerizada}

Nesta seção são descritos os resultados obtidos com a polimerização eletroquímica de PAni sobre os aços inoxidáveis AISI 304, AISI 430 e AISI 430. A PAni foi eletropolimerizada seguindo o método descrito por Moraes [82] com algumas modificações, dentre essas modificações a escolha do eletrólito, ácido oxálico $0,3 \mathrm{~mol} \mathrm{~L}^{-1}$, foi baseada em resultados anteriores obtidos em nosso grupo de pesquisa [83], a concentração de anilina utilizada foi de $0,1 \mathrm{~mol} L^{-1}$. 
Desta forma, a escolha do método, ou seja, a formação do filme por voltametria em condições já descritas na parte experimental, resultou em um filme aderente à superfície do eletrodo. Os intervalos de potenciais e a velocidade de varredura de potenciais foram determinados como descrito na seção 3. 6.2 da parte experimental.

Também é descrita a caracterização dos filmes de PAni obtidos sobre os eletrodos. Esta caracterização foi feita através da resposta eletroquímica dos filmes de PAni, espectroscopia na região do ultravioleta (UV-vis-NIR) do polímero, espectroscopia na região do infravermelho (IV) e microscopia eletrônica de varredura dos filmes de PAni, dos filmes estavam na forma dopada e desdopada.

\section{1.1 - Eletropolimerização de PAni}

A primeira etapa de eletropolimerização de PAni foi constituída de um ciclo voltamétrico num intervalo de potenciais de $-0,6$ a 1,8 V, com uma velocidade de varredura de $50 \mathrm{mV} \mathrm{s}^{-1}$, em uma solução contendo $0,1 \mathrm{~mol} \mathrm{~L}^{-1}$ de anilina em meio de ácido oxálico $0,3 \mathrm{~mol} \mathrm{~L}^{-1}$. Esta varredura promove a formação de uma fina camada de óxidos e oxalato metálico sobre a superfície do eletrodo, assim como, promove a oxidação do monômero de anilina.

$\mathrm{Na}$ Figura 8 pode ser observados para os três aços o processo (a), que corresponde a um acoplamento dos processos de formação da camada de óxidos e oxalatos metálicos e a oxidação do monômero de anilina. Para os aços AISI 304 e AISI 430 (A e B, respectivamente), o processo (a) não tem alteração significativa na magnitude de corrente, mas existe um deslocamento de potencial nos processos de oxidação do aço AISI 304.

Para o aço AISI 420 (C) são observados os processos: (b) que é atribuído à oxidação ferro do substrato metálico e o processo (a) que possui maior magnitude de corrente, em relação aos aços AISI 304 e AISI 430, existindo também, um deslocamento de potenciais no processo de acoplamento (a). Esta grande diferenciação dos processos de acoplamento do aço AISI 420 com relação aos demais aços, deve-se ao fato deste aço promover a formação de uma camada de oxalato mais espessa do que para os demais aços. 


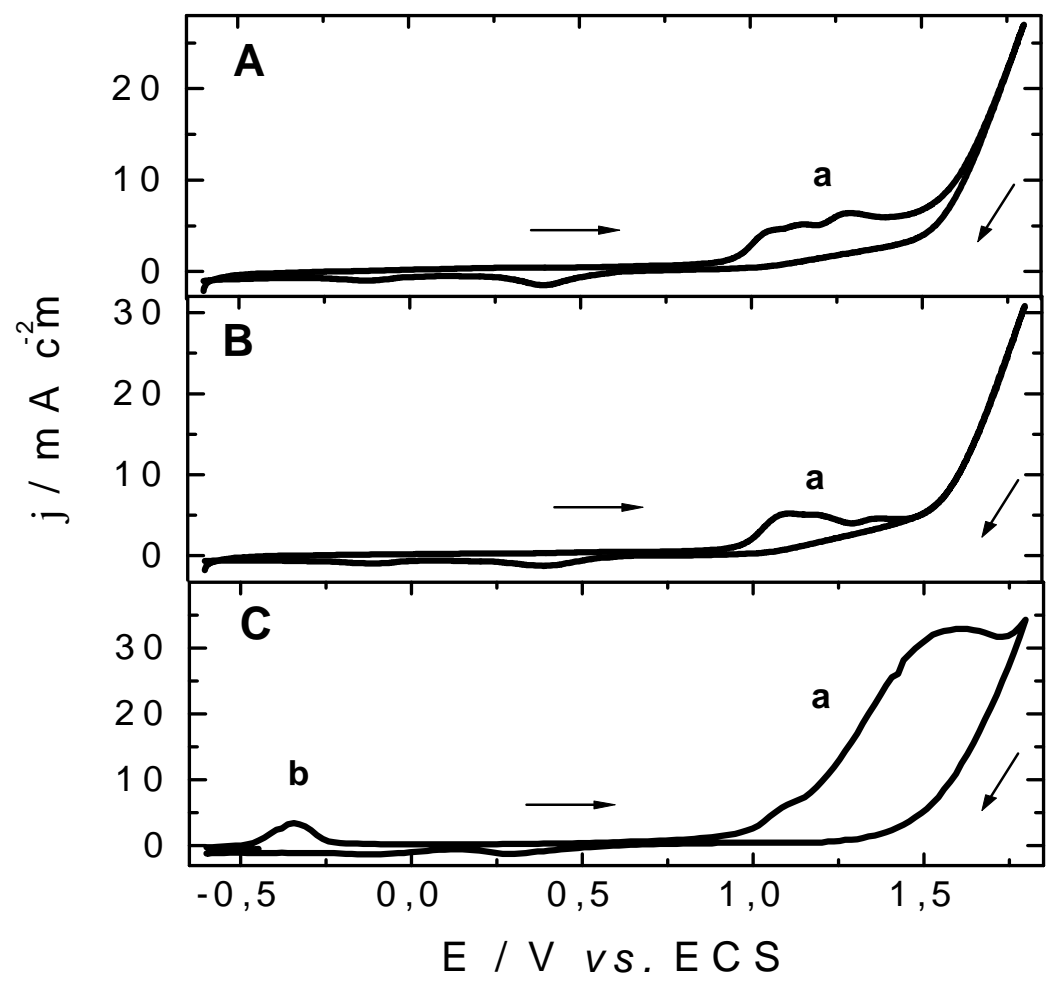

Figura 8 - Voltamogramas cíclico da primeira etapa de eletropolimerização de PAni sobre os aços: (A) AISI 304; (B) AISI 430 e (C) AISI 420, com velocidade de varredura de $50 \mathrm{mV} \mathrm{s}^{-1}$.

Após a etapa inicial de polimerização, foram feitos 89 ciclos em um intervalo de potenciais de $-0,2$ a 0,8 V. Na Figura 9 são mostrados o último voltamograma, destacado em linha pontilhada e os trinta primeiros voltamogramas para os três aços. São observados para os aços AISI 304 (A) e AISI 430 (B): um pico (a) com valor em torno de $0,2 \mathrm{~V}$, que é atribuído ao primeiro processo de oxidação da PAni (interconversão do estado leucoesmeraldina a esmeraldina), dois processos, (b) e (c) a 0,5 e 0,65 V, respectivamente. Estes processos correspondem aos processos de degradação do polímero (0,49 $\mathrm{V}$ - par redox quinona/hidroquinona) [32,40] e ao segundo processo de oxidação do polímero $(0,65 \mathrm{~V}$ interconversão do estado esmeraldina e pernigranilina). Logo após o final desta etapa pode ser visualmente observada a formação de um filme verde sobre a superfície do eletrodo, indicando a formação de PAni no estado sal de esmeraldina. 


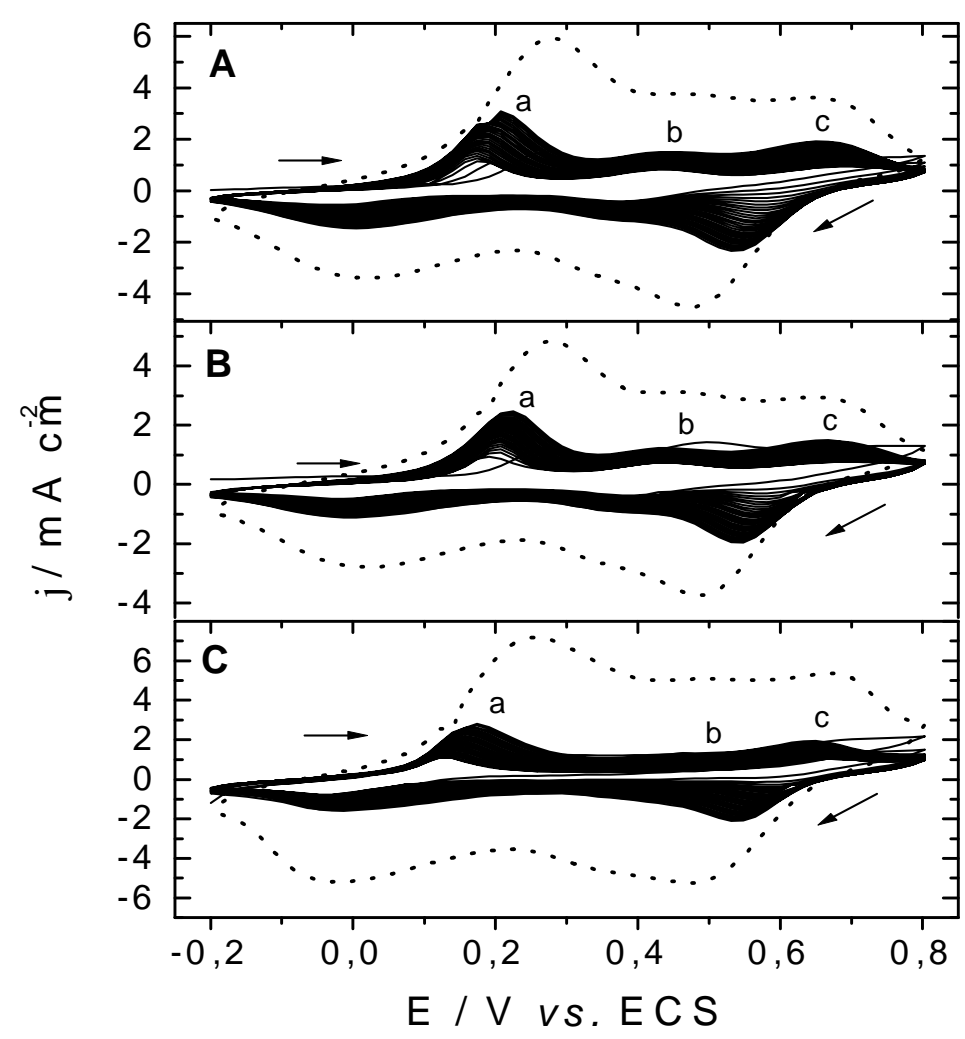

Figura 9 - Voltamogramas: (-) 30 ciclos e (…) último ciclo da eletropolimerização do filme de PAni sobre (A) aço AISI 304, (B) AISI 430 e (C) AISI 430, com velocidade de varredura de $50 \mathrm{mV} \mathrm{s}^{-1}$.

Para o aço AISI 420 (C), devido à diferença de composição em relação aos outros aços, observa-se que a densidade de corrente gerada no processo de polimerização de PAni é maior (cerca de 2 vezes) em relação aos demais aços. Quanto ao potencial do pico (a), interconversão do estado leucoesmeraldina a esmeraldina, para o aço AISI-420, não ocorre deslocamento significativo. Entretanto, para os processos (b) e (c) ocorre um deslocamento de potenciais para valores mais positivos. Este deslocamento pode ser decorrente de diferentes fatores dentre quais: a menor quantidade de cromo presente na microestrutura, em relação aos outros aços que possuem teores de cromo equivalentes em suas composições nominais.

Após o término destas etapas de eletropolimerização, observa-se na superfície dos eletrodos a formação de um filme de cor verde, indicativo da formação do polímero PAni na forma dopada. 


\section{1.2 - Caracterização do filme de PAni}

\section{1.2.1 - Resposta eletroquímica}

A estabilidade eletroquímica e a eletroatividade dos polímeros foram avaliadas com a técnica de voltametria cíclica. As respostas eletroquímicas foram obtidas em solução de ácido oxálico $0,3 \mathrm{~mol} \mathrm{~L}^{-1}$, isenta de monômero, no intervalo de potencial de $-0,2$ a $0,8 \mathrm{~V}$, com velocidade de varredura $0,5 \mathrm{mV} \mathrm{s}^{-1}$. Na Figura 10 são apresentados os voltamogramas das respostas eletroquímicas para os aços: $(A)$ AISI 304, (B) AISI 430 e (C) AISI 420.

Pela Figura 10, três pares de picos redox podem ser observados, em concordância com os resultados descritos na literatura [32,38,40,45]: pico a/a' ( 0,2/$0,05 \mathrm{~V}$ ) atribuído ao primeiro processo de oxidação da PAni (interconversão do estado leucoesmeraldina a esmeraldina), pico b/b' ( 0,5/0,4 V) correspondente aos processos de degradação do polímero (par redox quinona/hidroquinona) e pico c/c' ( 0,7/0,6 V) atribuído ao segundo processo de oxidação do polímero (interconversão do estado esmeraldina e pernigranilina).

Comparando as respostas eletroquímicas para os três aços, é observada uma diminuição na densidade de corrente do processo b/b' para o aço AISI 420. Esta diminuição é indicativa de existe uma diferença na composição deste em relação aos demais

Desta forma, a análise do comportamento eletroquímico do polímero e a comparação dos valores dos pares redox apresentados, com os relatados na literatura, evidenciam que a formação do filme de PAni sobre os aços inoxidáveis. 


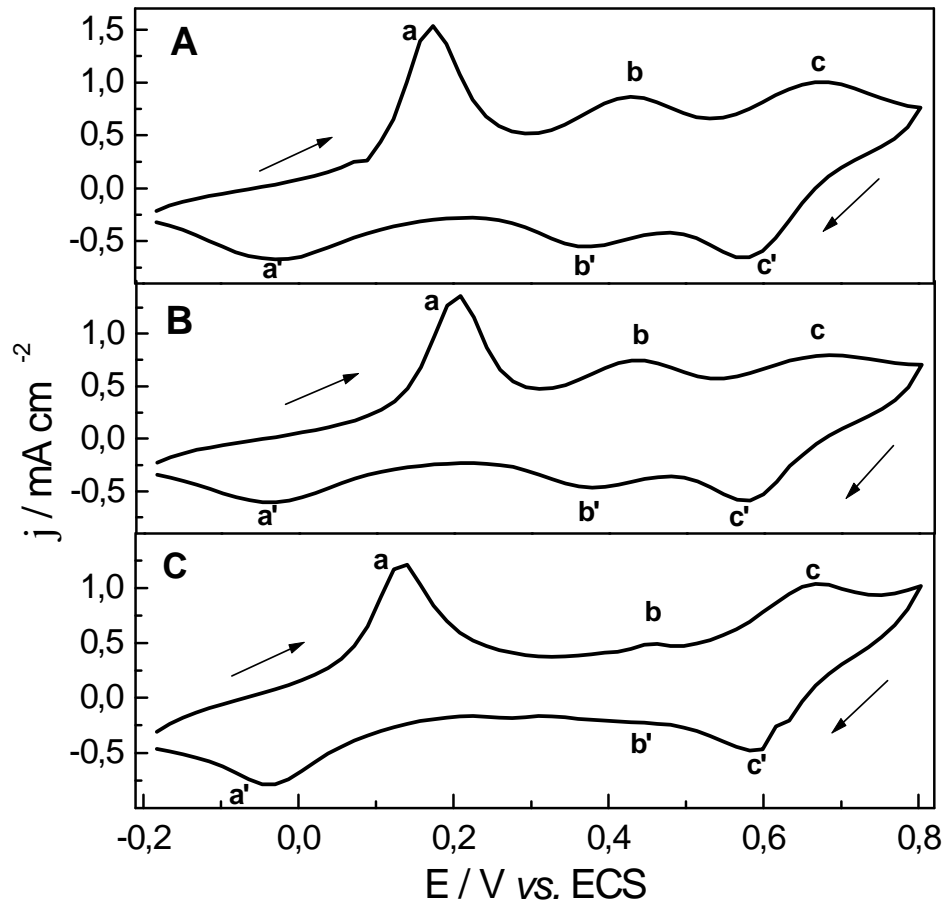

Figura 10 - Demonstração do $5^{\circ}$ ciclo da resposta eletroquímica dos filmes de PAni eletropolimerizados, em ácido oxálico $0,3 \mathrm{~mol} \mathrm{~L}^{-1}$, sobre os aços: (a) AISI 304, (b) AISI 430 e (c) AISI 420, com velocidade de varredura de $50 \mathrm{mV} \mathrm{s}^{-1}$.

\section{1.2.2 - Espectroscopia na região do UV-vis-NIR}

As análises dos espectros de UV-vis-NIR correspondentes aos polímeros dopados e desdopados foram realizados a partir de soluções diluídas de PAni em NMP, sendo a desdopagem realizada como descrito na seção 3. 7.1. Para a análise do polímero na forma dopada, foi adicionado a solução de polímero, $\mathrm{HCl} 5,0 \mathrm{~mol} \mathrm{~L}^{-1}$ como agente dopante, minutos antes da análise espectral. Nas Figuras 11 e 12 são mostrados os espectros correspondentes a PAni eletropolimerizada sobre os diferentes aços inoxidáveis, em solução de ácido oxálico na forma dopada e desdopada

A solução do polímero, na forma desdopada, apresenta uma coloração azul. No espectro de absorção de PAni desdopada (Figura 11) podem ser observadas duas bandas de absorção, características [32,84]: as transições $\pi-\pi^{*}$ dos anéis benzênicos, com valor de comprimento de onda ao redor de $340 \mathrm{~nm}$ e uma banda, 
ao redor de $640 \mathrm{~nm}$, atribuída à transferência de carga entre os anéis quinóides e benzenóides.

Quando o polímero é dopado, uma coloração verde pode ser observada nas soluções, promovida pela formação do sal esmeraldina. Assim, na Figura 12, é observada uma nova banda ao redor de $380 \mathrm{~nm}$, atribuída aos radicais cátions que se formam é observada. Uma banda larga ao redor de $830 \mathrm{~nm}$, associada aos transportadores de cargas na cadeia polimérica, ou seja, as transições das bandas excitônicas para as bandas bipolarônicas, também podem ser observadas.

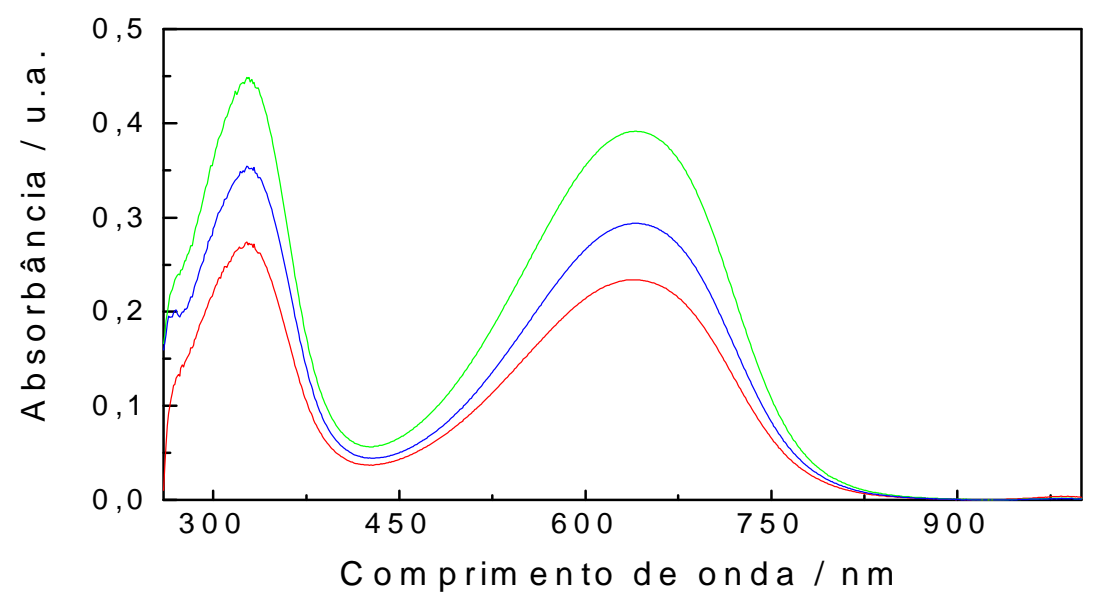

Figura 11 - Espectro de absorção de UV-vis-NIR de PAni, na forma desdopada para os aços AISI $304(-)$, AISI $430(-)$ e AISI $420(-)$.

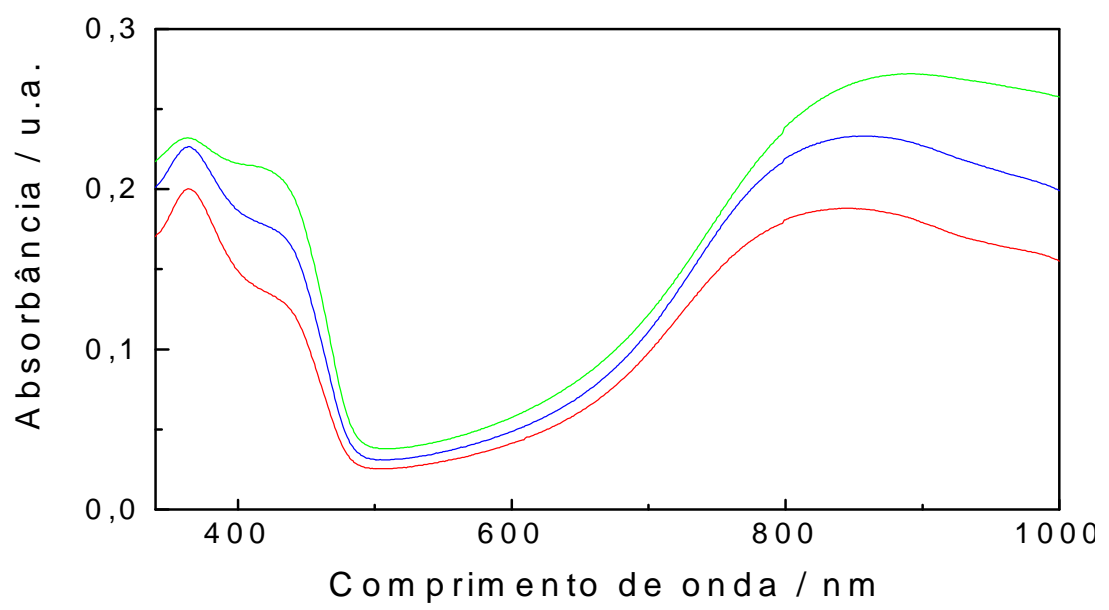

Figura 12 - Espectro de absorção de UV-vis-NIR de PAni, na forma dopada para os aços AISI $304(-)$, AISI $430(-)$ e AISI $420(-)$. 


\section{1.2.3- Espectroscopia no infravermelho (IV)}

Os espectros na região do infravermelho (IV), obtidos para os polímeros desdopados e dopados. são apresentados nas Figuras 13 e 14 respectivamente

Uma análise da estrutura e das variações estruturais dos polímeros na forma dopada e desdopada dos polímeros pode ser vistas a seguir:

(a) As bandas a 1585 e $1495 \mathrm{~cm}^{-1}$ são atribuídas aos estiramentos vibracionais das ligações C-C correspondentes aos anéis quinóides e benzenóide, respectivamente.

(b) As bandas ao redor de 1299 e $1305 \mathrm{~cm}^{-1}$ correspondem às ligações $\mathrm{N}-\mathrm{H}$ e aos componentes simétricos dos modos de estiramentos das ligações $\mathrm{C}-\mathrm{C}$ ou C-N.

(c) As bandas a $1157,825-700 \mathrm{~cm}^{-1}$ são atribuídas aos modos de vibração $\mathrm{C}-\mathrm{H}$ no plano e fora do plano, respectivamente.

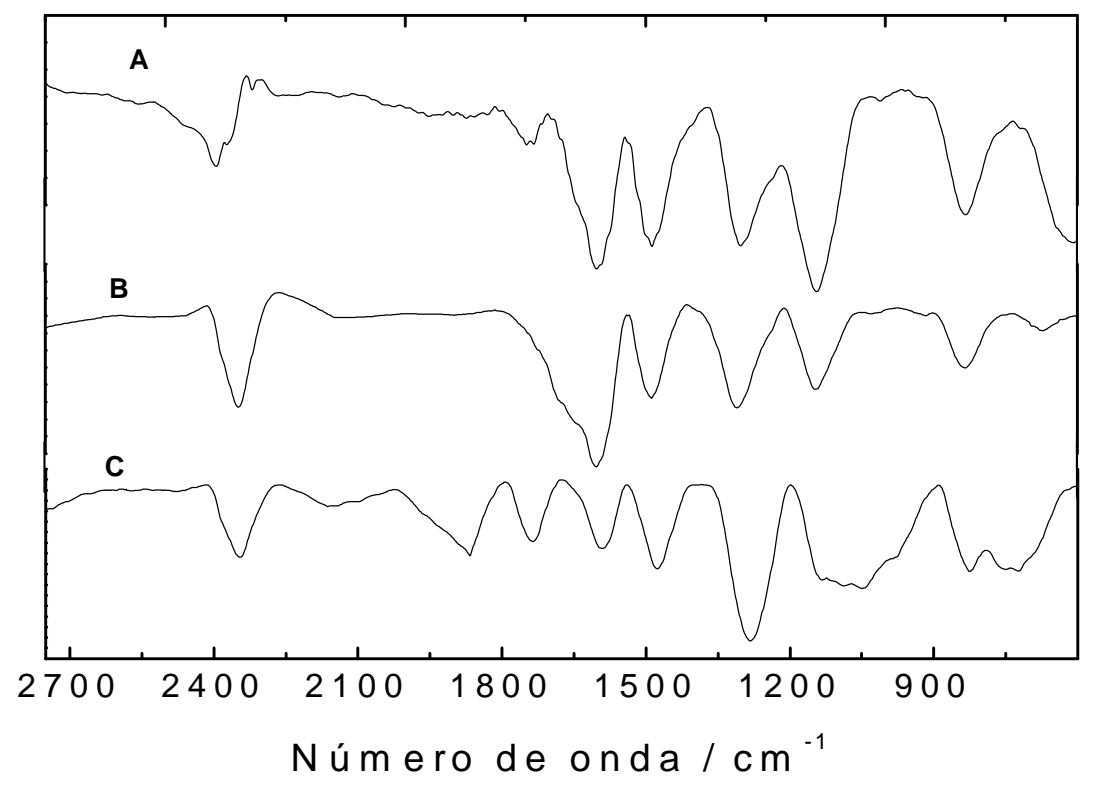

Figura 13 - Espectro de absorção de PAni no infravermelho (IV), na forma desdopada para os aços: (A) AISI 304, (B) AISI 430 e (C) AISI 420. 


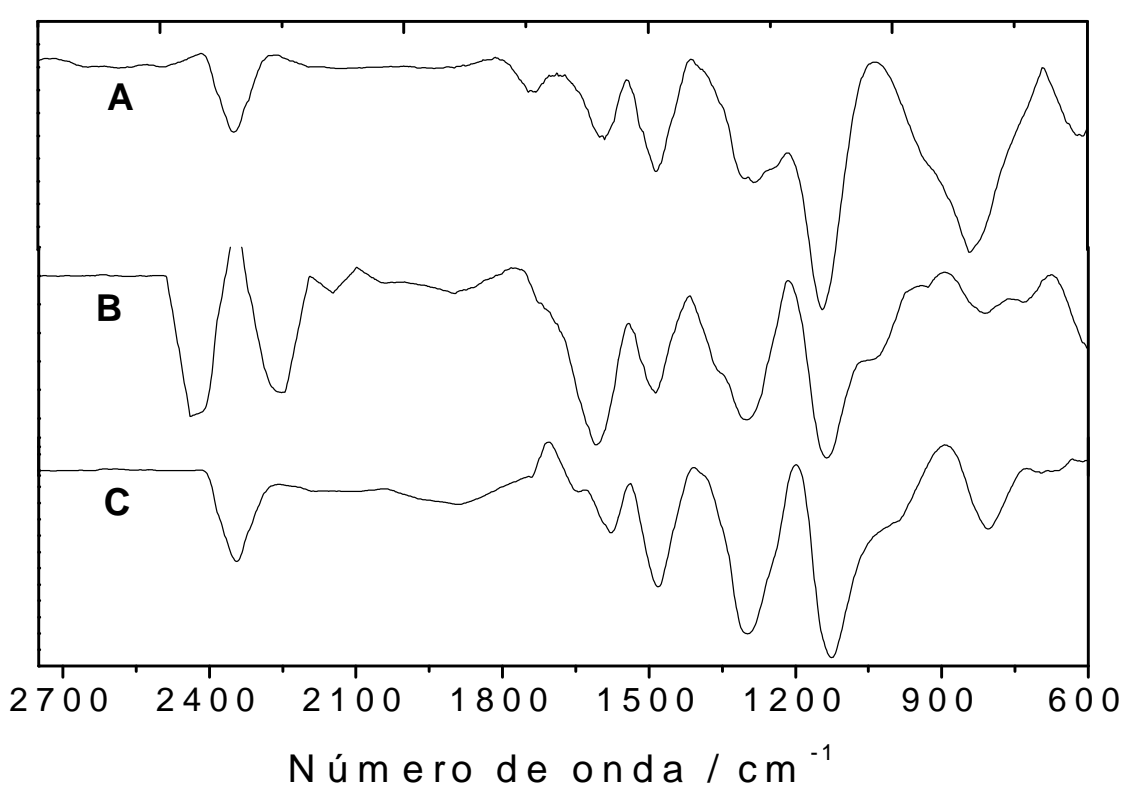

Figura 14 - Espectro de absorção de PAni no infravermelho (IV), na forma dopada para os aços: (A) AISI 304, (B) AISI 430 e (C) AISI 420.

A PAni na forma dopada apresenta uma transferência dos modos vibracionais das bandas ao redor de 1585 e $1495 \mathrm{~cm}^{-1}$ para menores comprimentos de onda. Isto ocorre devido ao processo de dopagem, a interação eletrostática entre a cadeia polimérica e o ânion dopante causa uma transformação na estrutura.

Os espectros para os filmes poliméricos obtidos a partir de solução de ácido oxálico foram comparados com os descritos por Chen et al. [85] e Sazou et al. [65] e não demonstraram diferenças significativas.

\section{1.2.4 - Microscopia eletrônica de varredura (MEV)}

$\mathrm{Na}$ Figura 15 são apresentadas as micrografias obtidas por MEV das superfícies dos aços AISI-304, AISI-420 e AISI-430 recobertos com filmes de PAni eletropolimerizados em solução de ácido oxálico $0,3 \mathrm{~mol} \mathrm{~L}^{-1}$. Os filmes poliméricos de PAni, independente do aço demonstram uma estrutura globular.

Algumas diferenças na morfologia dos polímeros ocorrem para os aços AISI 304 e AISI 430 (Figura 15a e 15b), os quais apresentam-se um filme homogêneo e 
os glóbulos são empacotados, de forma densa e conseqüentemente mais compactada. Enquanto, que para o aço AISI 420 (Figura 15c) é formado um filme uniforme de morfologia globular e porosa, formando uma superfície irregular.

Essas diferenças nas características de formação desses filmes são decorrentes de irregularidades no crescimento do polímero, que podem ser atribuídas principalmente à natureza do substrato (facilidade de oxidação da superfície e microestrutura do metal).
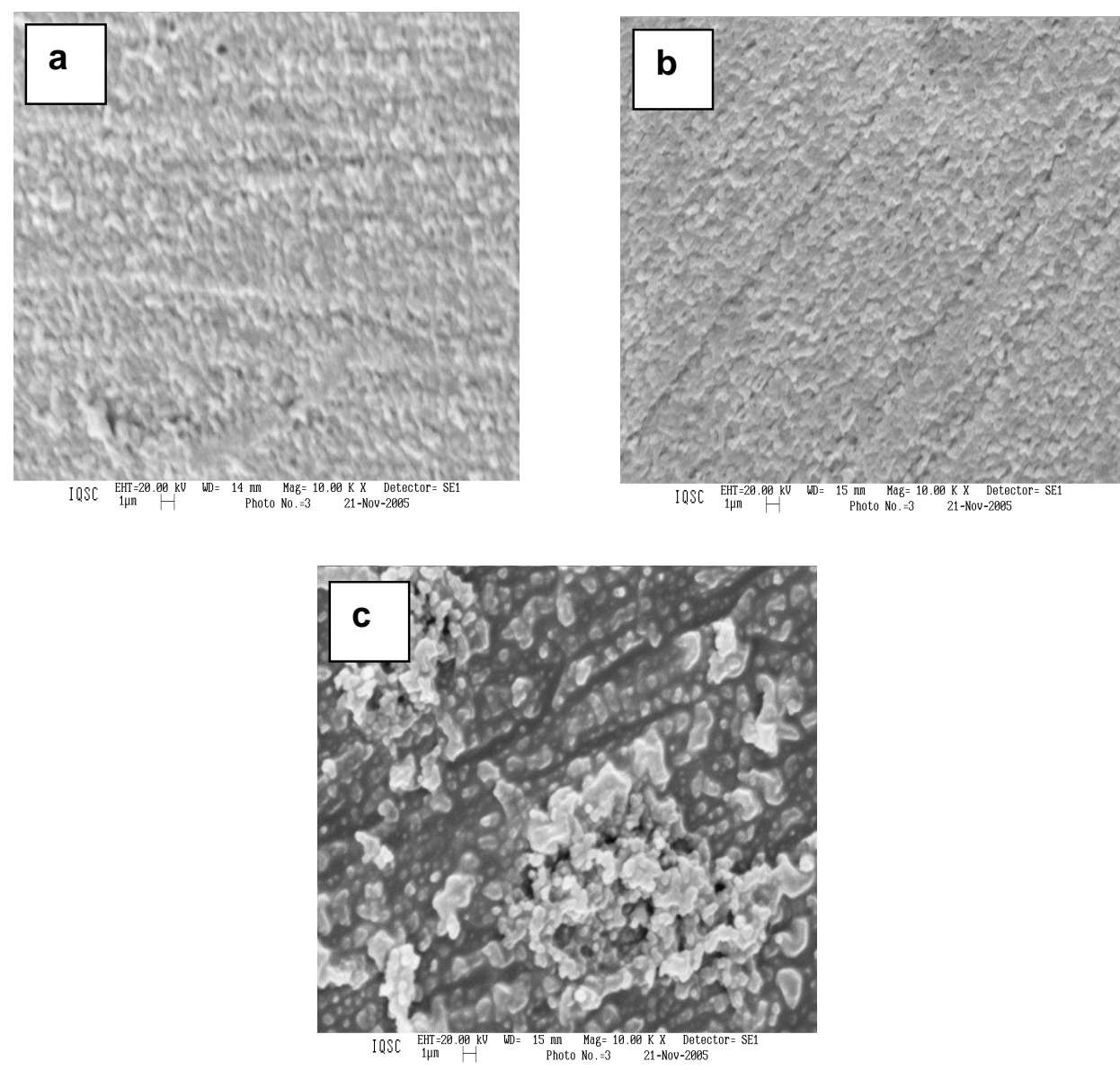

Figura 15 - Micrografias dos filmes de PAni eletropolimerizados em ácido oxálico 0,3 mol L'-1 sobre os aços (a) AISI 304, (b) AISI 430 e (c) AISI 420. Ampliação de 10.000 vezes.

A morfologia globular obtida para os filmes de Pani, eletropolimerizados sobre aço inoxidável, está em concordância com os resultados relatados na literatura. Nesses estudos Sazou [86] descreve a eletrossíntese de PAni sobre aço inoxidável 
AISI 304, no qual é observado que a morfologia do filme de PAni se apresenta na forma globular, com empacotamento denso, semelhante aos obtidos nesse estudo. A mesma morfologia globular foi observada por Deberry [58] para o aço AISI 430. Entretanto até o momento não forma encontrados relatos em literatura, que descrevem a morfologia de PAni-oxálico eletropolimerizada sobre o aço AISI 420.

\section{2 - Estudo da formação do filme de PAni}

Nesta seção é proposto um mecanismo de formação do filme de PAni sobre os aços inoxidáveis, baseado em estudos das variações das cargas anódicas totais em relação ao número de ciclos de potenciais durante o processo inicial de nucleação; da formação da camada de oxalato metálico sobre a superfície dos diversos aços e do polímero (o sal de esmeraldina), em espectroscopia de impedância eletroquímica (EIS) nos estágios iniciais de nucleação do filme de PAni e, finalmente em resultados de difração de raios $X$ de ângulo rasante. Desta forma foi possível propor um mecanismo de deposição dos filmes PAni sobre os diferentes aços com o intuito de compreender possíveis diferenças de comportamento apresentadas frente aos processos de corrosão.

\section{2.1 - Estudo comparativo das cargas totais anódicas, difração de raios $\mathrm{X} e$} EIS.

O primeiro estudo comparativo das cargas totais anódicas, geradas nos processos de oxidação dos aços inoxidáveis, foi o realizado a partir dos estágios iniciais de nucleação do polímero sobre os aços. Para isto, os aços foram submetidos a um ciclo de varredura de potencial em um intervalo de $-0,6$ a 1,8 V, a velocidade de $50 \mathrm{mV} \mathrm{s}^{-1}$, em uma solução de ácido oxálico $0,3 \mathrm{~mol} \mathrm{~L}^{-1}$ contendo 0,1 mol L ${ }^{-1}$ de anilina. 
A Figura 16 apresentam os voltamogramas cíclicos para os aços inoxidáveis, destacando a varredura de potenciais do ramo anódico. O objetivo de se apresentar esta varredura, está no fato de neste sentido da varredura acontecer os processos iniciais de nucleação do polímero, concomitantemente com os processos de oxidação de outras espécies, tais como oxidação do monômero, formação das camadas de óxidos e oxalatos metálicos, sobre o metal.

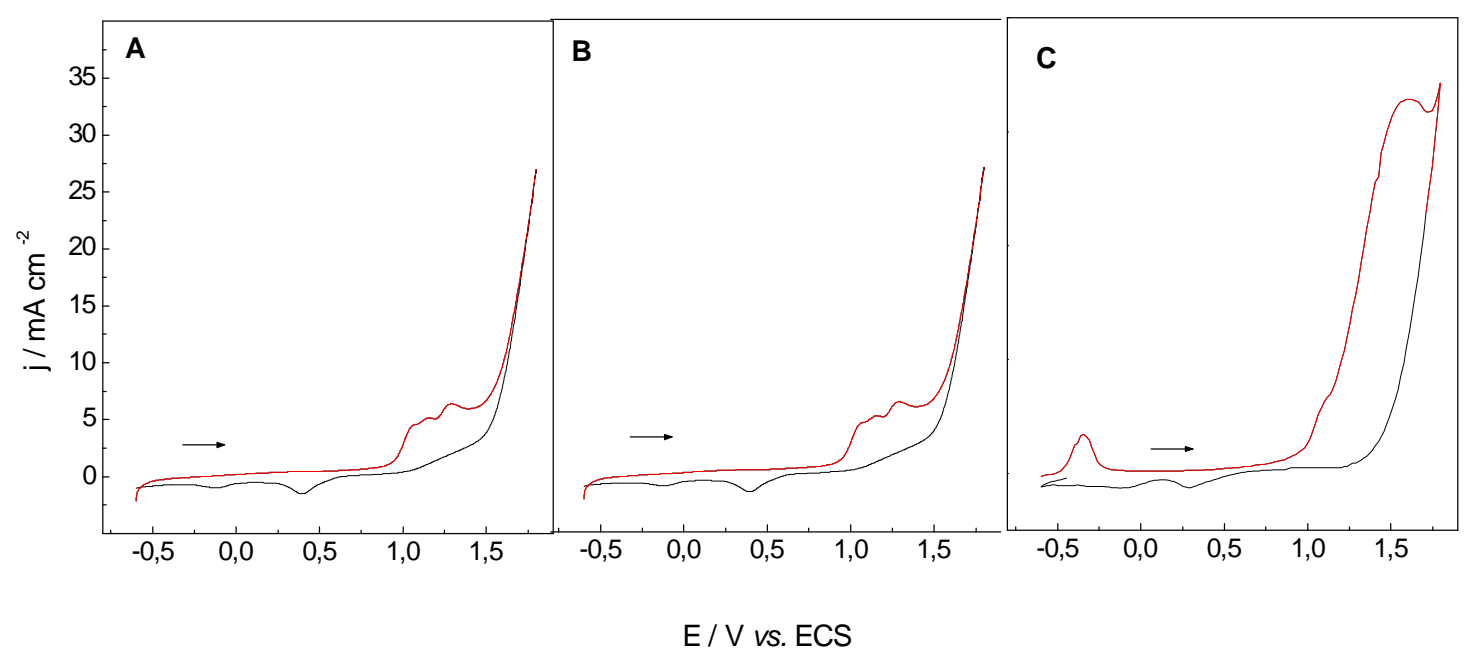

Figura 16- (a) Voltamograma do $1^{\circ}$ ciclo dos aços inoxidáveis: (A)AISI 304, (B) AISI 430 e (C) AISI 420. Na presença de solução de ácido oxálico $0,3 \mathrm{~mol} \mathrm{~L}^{-1}$ contendo $0,1 \mathrm{~mol} \mathrm{~L}^{-1}$ de anilina, com velocidade de varredura de $50 \mathrm{mV} \mathrm{s}^{-1}$.

Desta forma, foi calculada a carga total destes processos que ocorrem sobre a superfície dos aços inoxidáveis. Na Figura 17 pode ser observado que para o aço AISI 420, a carga total anódica formada, ou seja, a somatória de todos os processos de oxidação formados sobre a superfície metálica, é cerca de quatro vezes maior do que para os outros aços, indicando que existem mais espécies se oxidando na superfície do aço AISI 420 do que para os outros aços. Desta forma, pode-se dizer que há formação de uma camada mais espessa de óxidos e oxalatos metálicos sobre a superfície do aço AISI 420. 


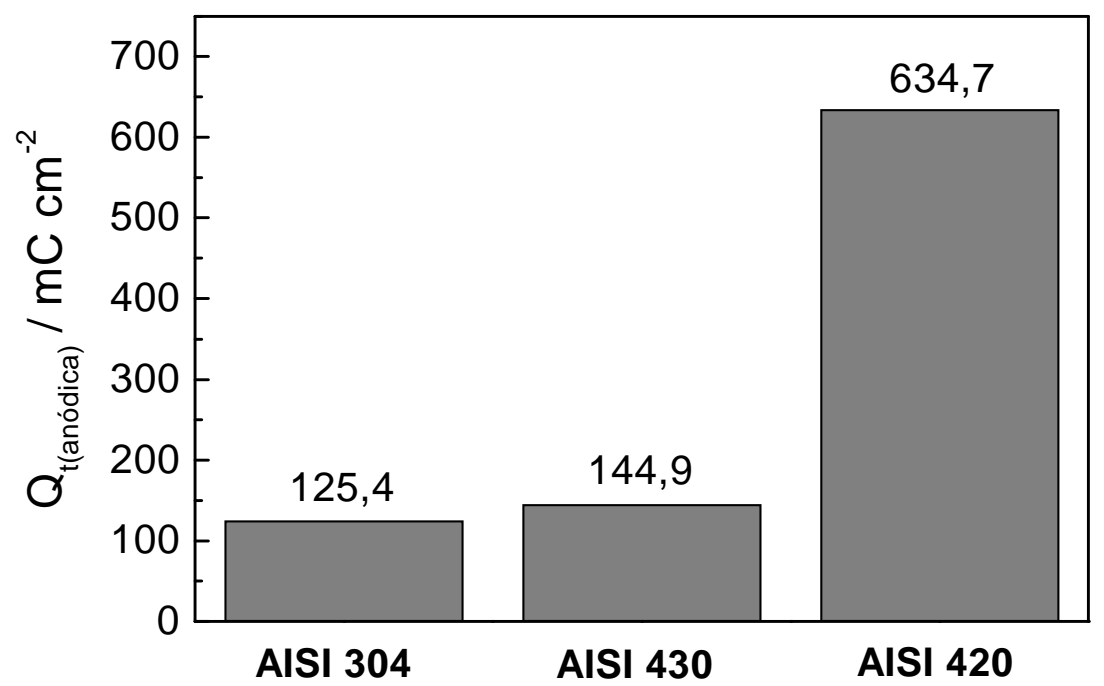

Figura 17 - Estudo do comparativo das cargas totais anódicas, obtidas a partir dos voltamogramas apresentados na Figura 16, para os aços inoxidáveis AISI 304, AISI 430 e AISI 420.

A mesma tendência pode ser observada quando se analisam os processos de formação polímero em ciclos de potenciais superiores ( $>2$ ciclos).

O estado de oxidação do polímero, sal esmeraldina, que corresponde a PAni no estado condutor, foi analisado e esta análise consistiu em verificar como a carga total deste processo (cerca de 0,3 V) aumenta para cada aço inoxidável, quando se aumenta o número de ciclos de varredura de potenciais.

A Figura 18 apresenta os valores comparativos das cargas calculadas a partir da área do processo formação do sal esmeraldina. Assim, utilizou-se os voltamogramas cíclicos de eletropolimerização do polímero, descritos na etapa 2 da seção 3. 6.2, sendo calculada, a cada 5 ciclos, a área do pico correspondente a formação do sal esmeraldina. Desta forma é inserida na Figura 18, a demonstração dos voltamogramas cíclicos, cuja área marcada corresponde ao processo de formação do sal esmeraldina. 


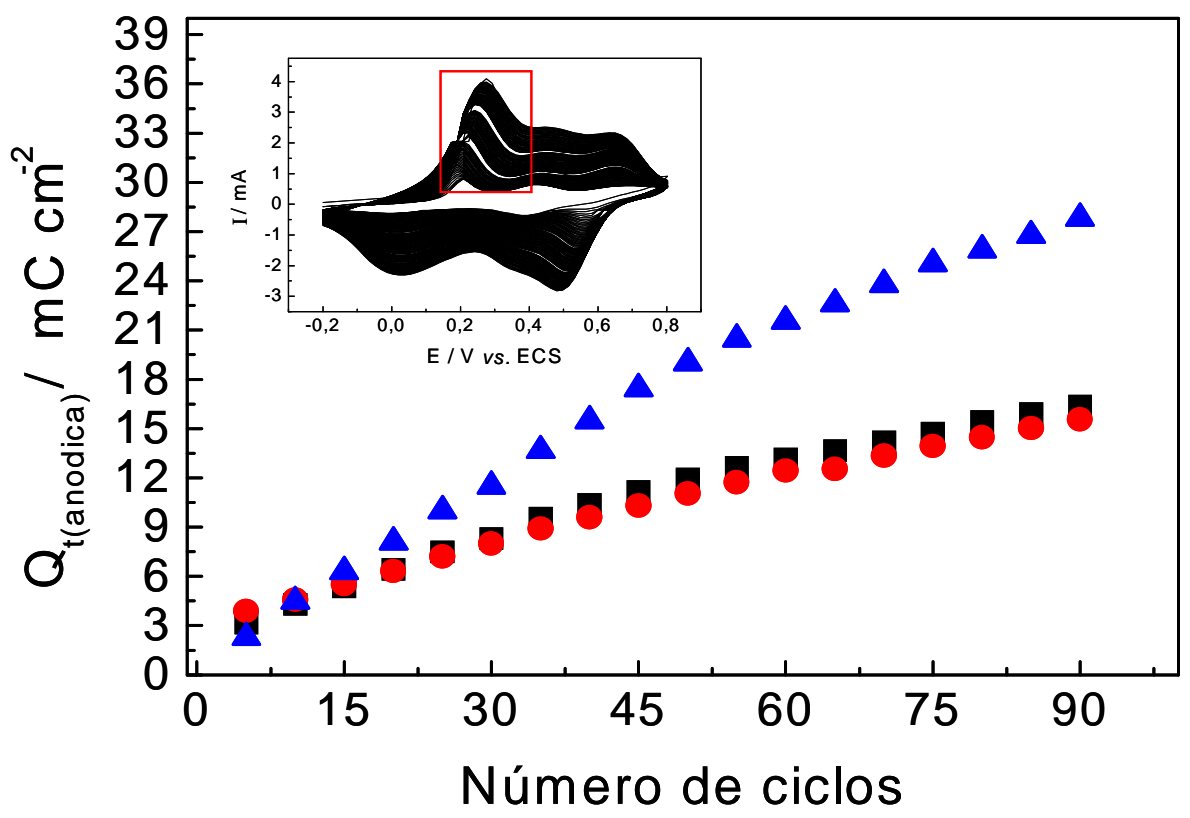

Figura 18 - Variação do número de ciclos em relação à carga de formação do sal esmeraldina para os aços: AISI 420,' AISI 430 e AISI 304. Inserção dos voltamogramas cíclicos do eletropolimerização de PAni - detalhe da área de cálculo da carga do processo de formação do sal esmeraldina.

Neste estudo pode ser observado, que o aço AISI 420 possui maior valor de carga total $(27 \mathrm{mC})$, quando o processo se finaliza em 89 ciclos. Como o processo de eletropolimerização do filme de PAni é influenciado por diferentes fatores, dentre eles: $\mathrm{pH}$ do meio, intervalo de potencial, velocidade de polimerização, a natureza do substrato e, portanto, a composição do aço, torna-se a única a influenciar no processo já que as demais se mantiveram constantes para todos os aços. Sendo assim, a natureza e a diferença na composição do aço AISI 420 faz com que exista uma diferença nos valores de carga do processo, podendo atingir cerca de duas vezes o valor da carga total para os aços AISI 304 e AISI 430.

A resposta eletroquímica dos aços (AISI-304, AISI-420 e AISI-430) sem recobrimento foi obtida em solução de ácido oxálico $0,3 \mathrm{~mol} \mathrm{~L}^{-1}$, utilizando a técnica de voltametria cíclica em cinco ciclos de potenciais (necessário para estabilização dos ciclos) e no intervalo de potencial de $-0,2$ a $0,8 \mathrm{~V}$, com velocidade de varredura de $50 \mathrm{mV} \mathrm{s}^{-1}$. 
$\mathrm{Na}$ Figura 19 é apresentado $\circ 5^{\circ}$ voltamograma cíclico para os aços inoxidáveis quando este é submetido a varredura em ácido oxálico $0,3 \mathrm{~mol} \mathrm{~L}^{-1}$. A varredura anódica de potenciais corresponde ao processo de oxidação da superfície metálica, com conseqüente formação de uma camada mista de óxidos e oxalato do metal.

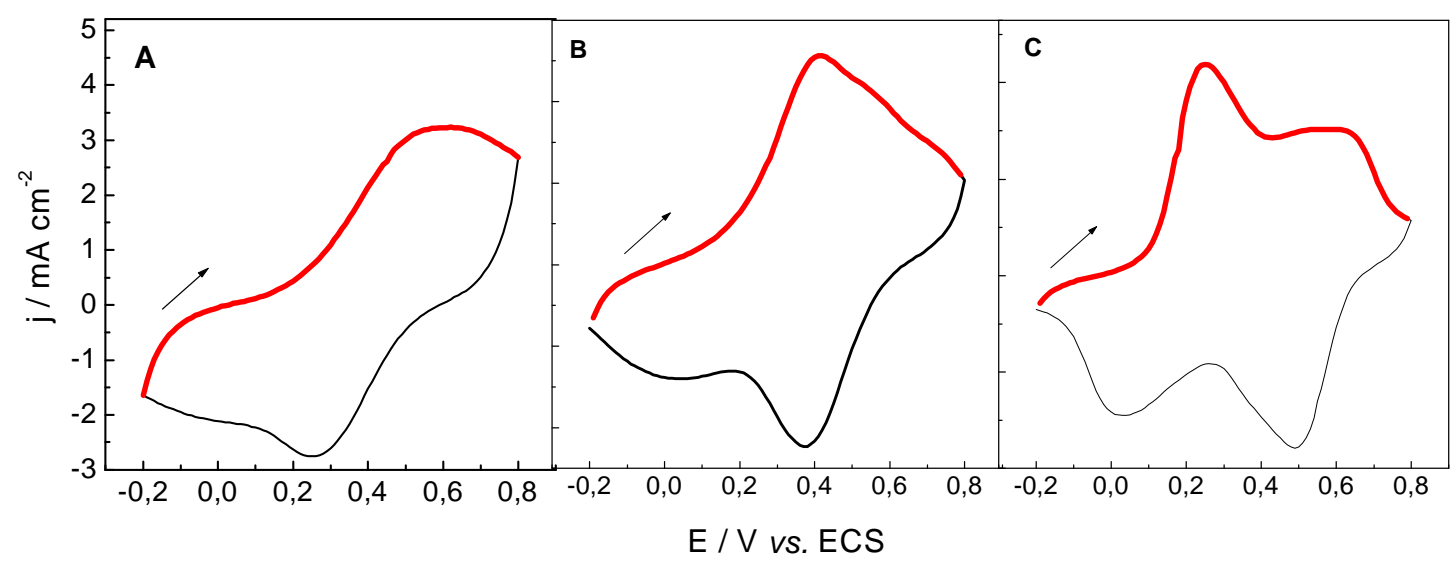

Figura 19 - Voltamograma do $5^{\circ}$ ciclo dos aços inoxidáveis: (A) AISI 304, (B) AISI 430 e (C) AISI 420. Na presença de solução de ácido oxálico 0,3 $\mathrm{mol} \mathrm{L}^{-1}$ isenta de anilina, com velocidade de $50 \mathrm{mV} \mathrm{s}^{-1}$.

A Figura 20 mostra o comportamento da variação das cargas anódicas totais formadas no processo de oxidação da superfície do aço em meio de ácido oxálico. É observada para o aço AISI 420 uma facilidade em se oxidar. Tendo em vista que, o aço AISI 420, possui menor quantidade de cromo em sua composição e segundo Souza [16] a resistência à corrosão de um aço inoxidável depende da formação de um filme superficial fino de óxido de cromo $\left(\mathrm{CrO}_{3}\right)$. Portanto a tendência de aumento da carga anódica total, observada para o aço AISI 420 em relação aos outros aços, indica que para o aço AISI 420 existe uma maior facilidade em formar camadas de óxido e oxalato sobre a superfície do metal. 


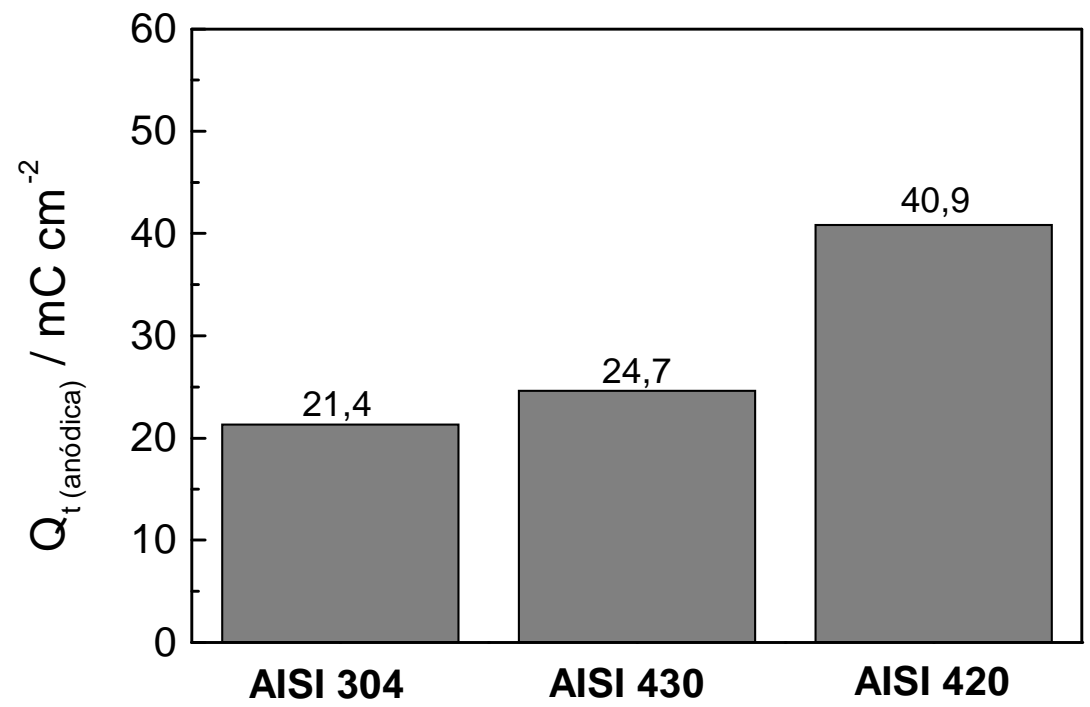

Figura 20 - Estudo do comparativo das cargas totais anódicas, obtidas a partir dos voltamogramas apresentados na Figura 25, para os aços inoxidáveis AISI 304, AISI 430 e AISI 420.

Para verificar a existência da formação de uma camada de oxalato, depositada sobre a superfície do aço AISI 420, foram realizadas análises de difração de raios $X$ com ângulo rasante.

$\mathrm{Na}$ análise do difratograma para o AISI 420 (Figura 21), observa-se uma grande quantidade de planos de difração para o composto oxalato de ferro. $\mathrm{Na}$ proximidade do ângulo de $50^{\circ}$ é observado um plano de difração referente a íons ferro (intensidade $\sim 225$ Counts). 


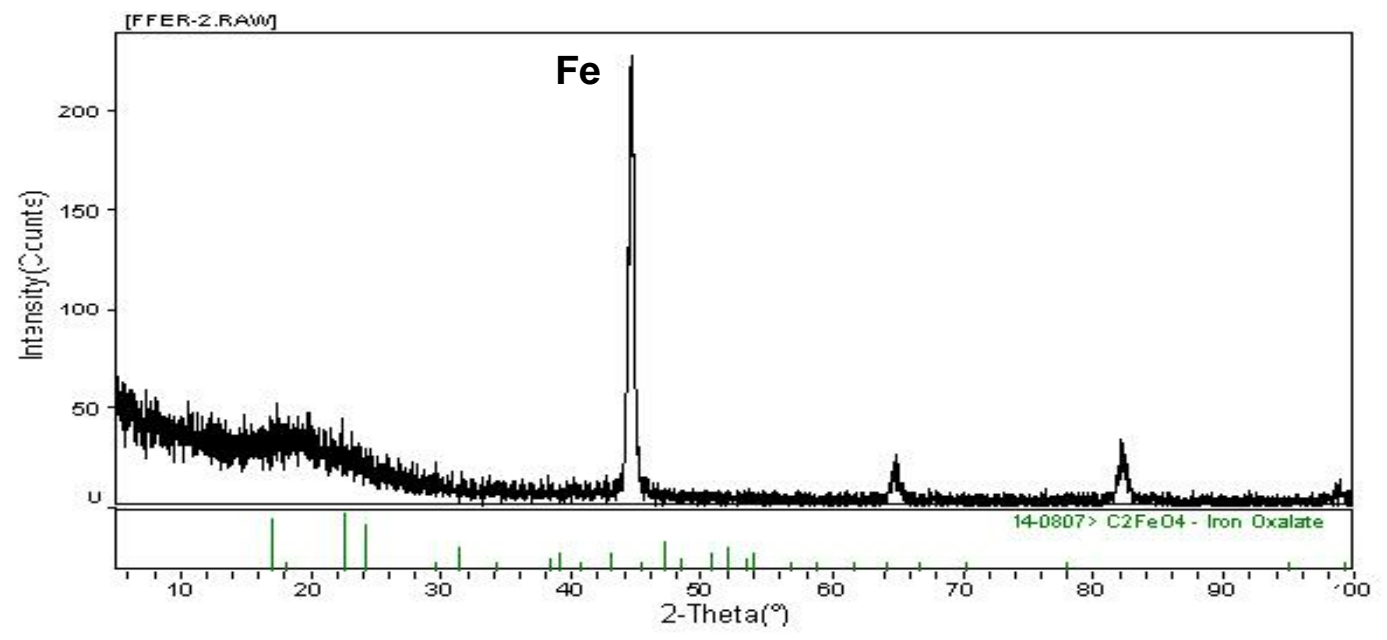

Figura 21 - Difratograma de raios X para o aço AISI 420, recoberto com filme de PAni, mostrando os planos de difração para o oxalato de ferro.

Para o aço AISI 430, Figura 22, existe uma significativa diminuição na presença destes planos de difração, referente a oxalato de ferro, confirmando a formação de uma mínima camada de oxalato de ferro, intermediária ao filme de PAni e a superfície metálica.

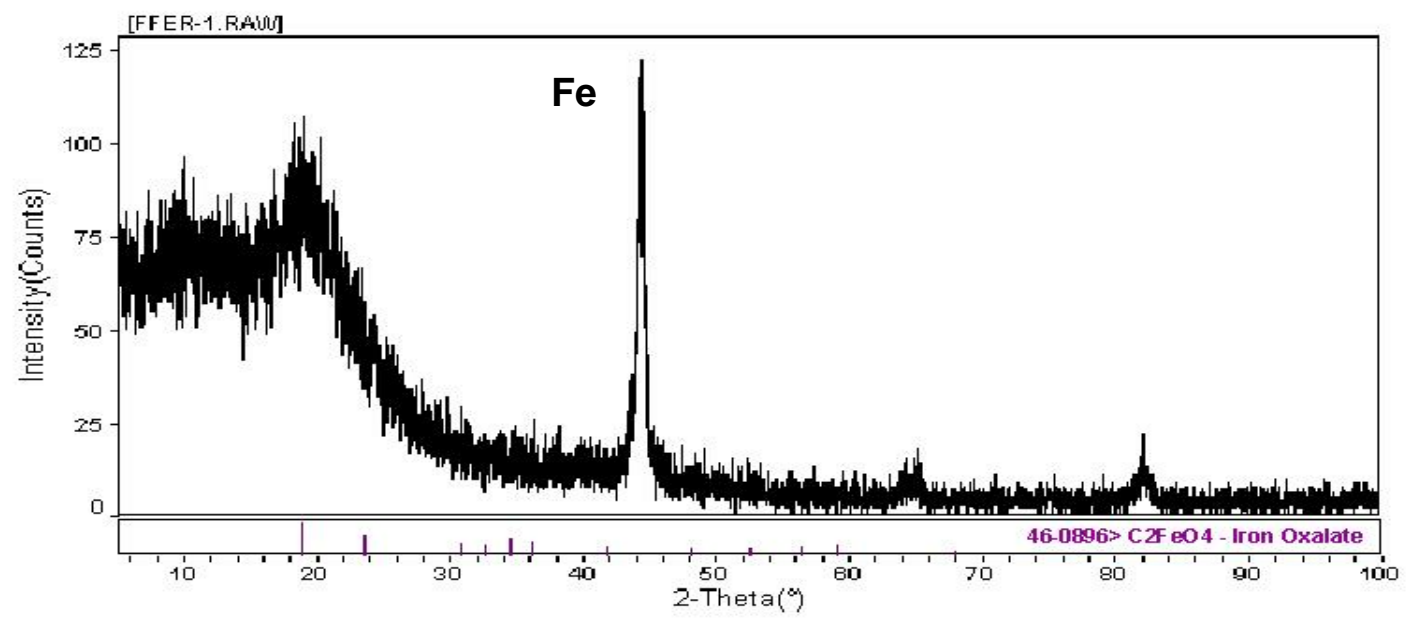

Figura 22 - Difratograma de raios X para o aço AISI 430, recoberto com filme de PAni, mostrando os planos de difração para o oxalato de ferro 
A comparação dos difratogramas mostra que, o aço AISI 420 possui maior quantidade de oxalato de ferro, do que para o aço AISI 430. Isto é evidenciado pelo número de planos de difração do oxalato de ferro, ser maior para o aço AISI 420. Outro ponto a se salientar, é o fato de o plano de difração para íons ferro presentes na superfície do aço, diminuir para o aço AISI 430, quando comparado ao aço AISI 420, indicando que existe uma menor interação entre o ferro do substrato e o ligante do polímero (complexo Fe-oxalato). Sendo que os resultados da análise de raios $X$ para o aço AISI 430 são semelhantes aos resultados obtidos para o aço AISI 304.

Portanto, os estudos que relacionaram as cargas formadas para cada aço, mostraram uma tendência que foi confirmada pela análise de difração de raios $X$. Esta tendência evidencia que para o aço AISI 420, forma-se uma camada mais espessa de óxidos e principalmente oxalatos de ferro sobre a superfície do metal, em relação aos outros aços. Esta camada dificulta a interação do filme de PAni com o substrato metálico, formando filmes mais porosos, menos aderentes e conseqüentemente menos protetores frente aos processos corrosivos.

Para realizar a análise de espectroscopia de impedância eletroquímica, os aços inoxidáveis foram submetidos a varreduras de potencial em solução de ácido oxálico $0,3 \mathrm{~mol} \mathrm{~L}^{-1}$, para se depositar uma camada de oxalato metálico. Esta deposição tem como finalidade simular os estágios iniciais de nucleação, quando esta camada se forma.

A Figura 23 mostram os diagramas de Nyquist para os aços recobertos com uma camada de oxalato.

O aço AISI 420, Figura 23a, o diagrama complexo apresenta-se na forma de dois semicírculos acoplados, onde pode ser visualizada uma componente difusional (área circulada). Esta componente difusional, segundo Melkior et al. [87], está relacionada com a natureza do filme, ou seja, a porosidade e a espessura do filme permitem afirmar que existe uma barreira, impedindo a difusão destas espécies até a superfície metálica. Bonel et al. [88] afirmam que a componente difusional, que ocorre a baixas freqüências está relacionada com as reações de espécies, provenientes do eletrólito, com o substrato metálico. Desta forma, esta barreira de oxalato de ferro permite que exista uma permeação de íons cloreto até a superfície 
do metal e esta permeação é visualizada pela componente difusional indicada pela freqüência baixa de $17,5 \mathrm{mHz}$
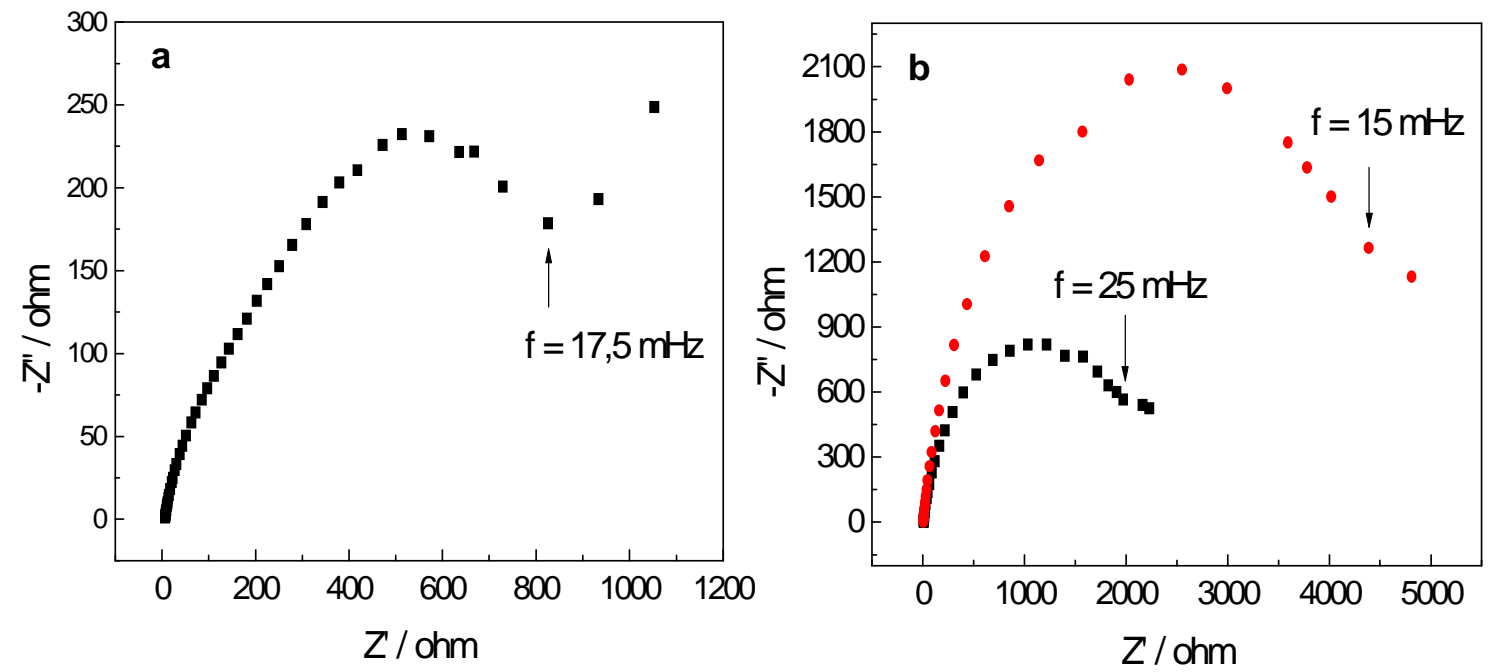

Figura 23 - Diagramas de Nyquist, para aços recobertos com filme de oxalato: (a) aço AISI 420 e (b) $\Upsilon$ AISI 304 e AISI 430.

Entretanto, esta componente observada para o aço AISI 420, não é apresentada para os aços AISI 304 e AISI 430, Figura 23b. Este fato é decorrente de a película de oxalato que se forma sobre esses aços ser ínfima, não apresentando, portanto este fator de difusão, na mesma magnitude de freqüência ( $f_{\text {baixa }} \sim 20 \mathrm{mHz}$ )

$\mathrm{Na}$ Figura 24 são apresentados os diagramas dos aços, quando estão recobertos com filme de PAni. Observa-se para os aços AISI 304 e AISI 430 a mesma componente difusional que foi descrita anteriormente. Esta componente pode ser atribuída ao efeito barreira, como descrito em literatura $[87,88]$. 

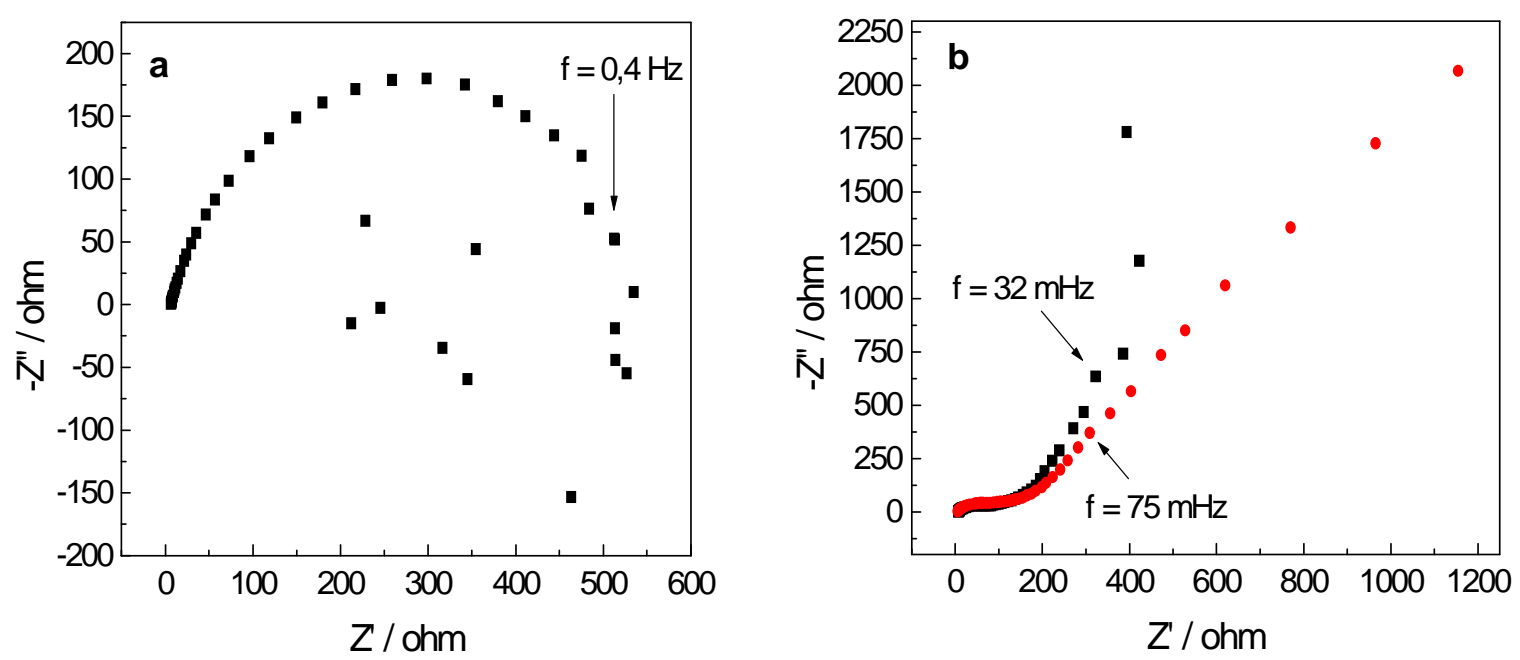

Figura 24 - Diagramas de Nyquist, para aços recobertos com filme de PAni: (a) aço AISI 420 e (b) $\Upsilon$ AISI 304 e AISI 430.

Entretanto, para o aço AISI 420, ao invés de se observar uma componente difusional, em freqüências baixas, como as apresentadas para os aços AISI $304 \mathrm{e}$ AISI 430, observa-se uma indutância, que ocorre na freqüência baixa de 0,4 Hz. Este comportamento é proveniente de revestimentos cuja porosidade é elevada [88]. Esta característica faz com que a resistência à permeação de espécies, provenientes do eletrólito, seja diminuta, desta forma a barreira que o revestimento efetua sobre o substrato torna-se ineficiente.

Essa ineficiência da barreira formada sobre o aço AISI 420, visualizada no diagrama da Figura 24a, é concordante coma morfologia dos filmes obtidos, como mostrado na Figura 15c, da seção 4. 1. Mostrando que um filme espesso de oxalato somado a um filme de PAni, formará uma barreira ineficaz.

$\mathrm{Na}$ Figura 24b é observada, em freqüências mais baixa (cerca de $50 \mathrm{mHz}$ ), a componente difusional atribuída ao efeito barreira. Esses filmes, conforme será visto no capítulo de ensaios de corrosão, oferecem uma maior proteção quando comparados ao aço AISI 420. 


\section{3 Proposição do mecanismo de eletropolimerização do filme de PAni.}

Através dos resultados obtidos na seção anterior, fica evidenciado que existe a formação de uma camada de oxalato, intermediária entre filme de PAni e o substrato metálico, sendo a partir destes resultados propor um mecanismo que explique a formação de filmes com morfologias diferentes.

No inicio da eletropolimerização, a superfície do metal é oxidada, levando a formação de óxidos e oxalato de ferro na superfície do metal. Na seqüência do processo de eletropolimerização, os primeiros núcleos de PAni se formam.

A formação do filme de PAni se diferencia na razão em que a natureza do substrato metálico é alterada, ou seja, para o aço AISI 420, foi constatada a formação de uma camada de oxalato de ferro (intermediaria entre a PAni e aço) mais espessa do que para os demais aços. Assim, a natureza do aço é o fator que permite a formação desta camada de oxalato, proporcionando a formação de um filme mais poroso e menos aderente.

A Figura 25, mostra a proposição do mecanismo de formação do filme de PAni sobre os diversos aços.

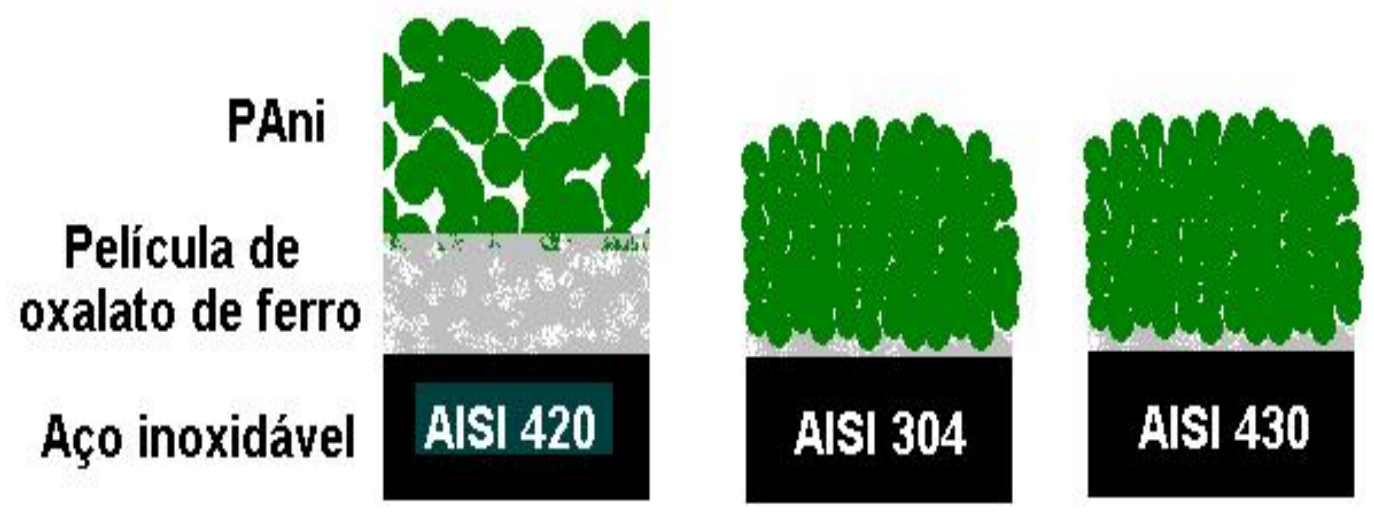

Figura 25 - Esquema de proposição do mecanismo de eletropolimerização de PAni sobre os aços inoxidáveis.

O teor de cromo presente na microestrutura dos aços pode promover uma variação na espessura da camada de oxalato de ferro. Segundo Souza [16], nos processos de oxidação de aços inoxidáveis, o cromo atua protegendo a superfície do aço devido à formação de uma fina camada de óxido de cromo. Com base neste 
estudo pode ser constatado que quanto maior o teor de cromo nos aços inoxidáveis estudados, mais difícil será a oxidação do ferro na superfície e, conseqüentemente menos espessa será a camada de oxalato, sendo assim, concordante com o mecanismo proposto.

\section{4 - Curvas de polarização para aos aços inoxidáveis sem recobrimento}

A caracterização do comportamento corrosivo dos aços inoxidáveis foi realizada através das curvas de polarização potenciodinâmicas e imagens de MEV obtidas antes e após a polarização. Estas caracterizações foram feitas como descrito no capitulo III, onde, foram realizadas curvas de polarização e MEV para os aços inoxidáveis do tipo: AISI 304, AISI 420 e AISI 430, com a finalidade de se estabelecer os parâmetros eletroquímicos dos aços tais como: potencial de corrosão $\left(E_{\text {corr }}\right)$; densidade de corrente de corrosão ( $\left.i_{\text {corr }}\right)$; potencial de pite ( $\left.E_{\text {pite }}\right)$ e taxa de corrosão (TC), como as características da superfície das amostras quando estas são atacadas por íons cloreto. As análises foram separadas para cada liga, sendo detalhados a seguir.

\section{4.1 - Aço AISI 304}

A curva demonstrada na Figura 26 foi registrada tendo o eletrodo imerso em uma solução de $\mathrm{NaCl} 3 \%$, a uma velocidade de varredura de $0,5 \mathrm{mVs}^{-1}$, em um intervalo de potencial de $-0,6$ a $0,3 \mathrm{~V}$, sendo que estes potenciais estão relacionados ao eletrodo de calomelanos saturado (ECS).

O aço AISI 304 apresentou um comportamento de corrosão ativo, após atingir o potencial de corrosão, é observado também um aumento na densidade de corrente no sentido positivo da varredura de potenciais. O aço inoxidável AISI 304 atingiu o potencial de corrosão em $E_{\text {corr }}=-0,180 \mathrm{~V}$ e seu potencial de pite em $E_{\text {pite }}=$ 0,094 V. A dissolução do metal ocorre no ponto $(A)$ da curva, sendo chamada de região ativa. Próximo ao ponto (B), a película isolante formada por óxidos metálicos (cromo, ferro e níquel) se dissolve, então a densidade de corrente de corrosão aumenta até chegar no potencial onde começa a região transpassiva $(\mathrm{C})$. Com o auxílio do programa M352 foi calculada a taxa de corrosão (T.C.) em micrômetros por ano ( $\mu \mathrm{ma})$, sendo este valor igual a 7,20 $\mu \mathrm{ma}$. 


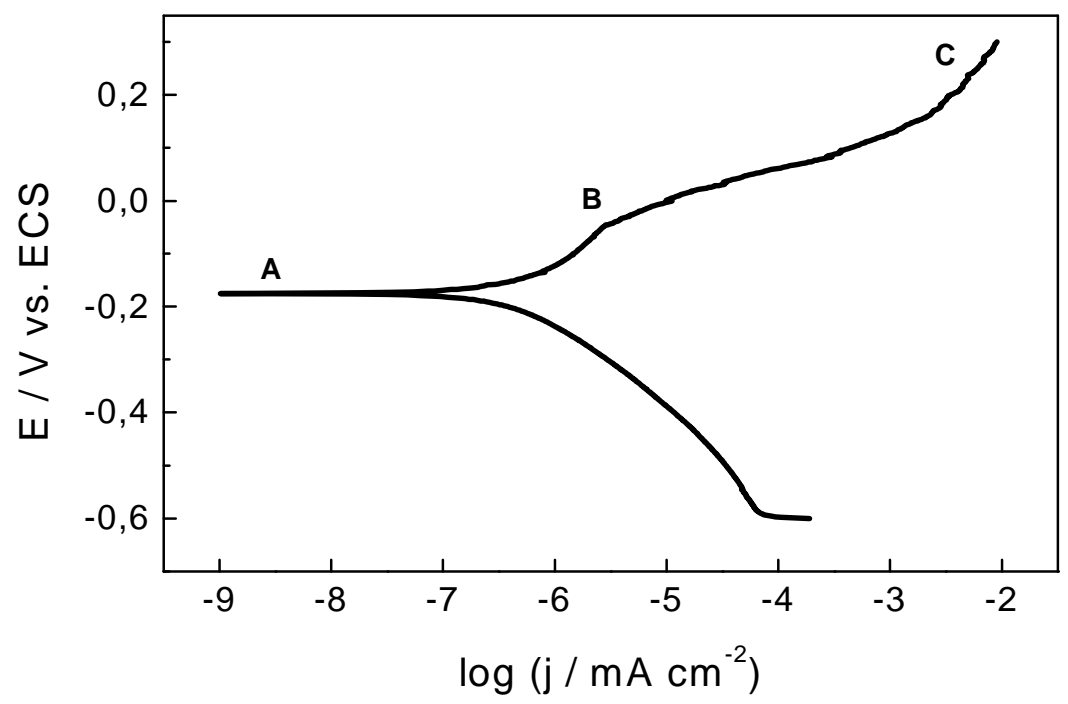

Figura 26- Curva de polarização potenciodinâmica do aço AISI 304, em solução de $\mathrm{NaCl} 3 \%$, com velocidade de varredura de $0,5 \mathrm{mVs}^{-1}$.

Este estudo feito para caracterizar os parâmetros eletroquímicos do aço inoxidável AISI 304, apresenta comportamento semelhante aos estudos relatados na literatura $[14,89]$. Nesses estudos os autores descrevem curvas de polarização potenciodinâmica para este tipo de aço, onde se verifica que o potencial de corrosão varia em torno de $-0,2 \mathrm{~V}$, valor este muito próximo do obtido no estudo acima ($0,180 \mathrm{~V})$.

O comportamento corrosivo do aço AISI 304, foi analisado através das imagens obtidas pela microscopia eletrônica de varredura antes e após a curva de polarização potenciodinâmica. A Figura 27 apresentam as imagens do aço antes da polarização (a) e após a polarização (b). 

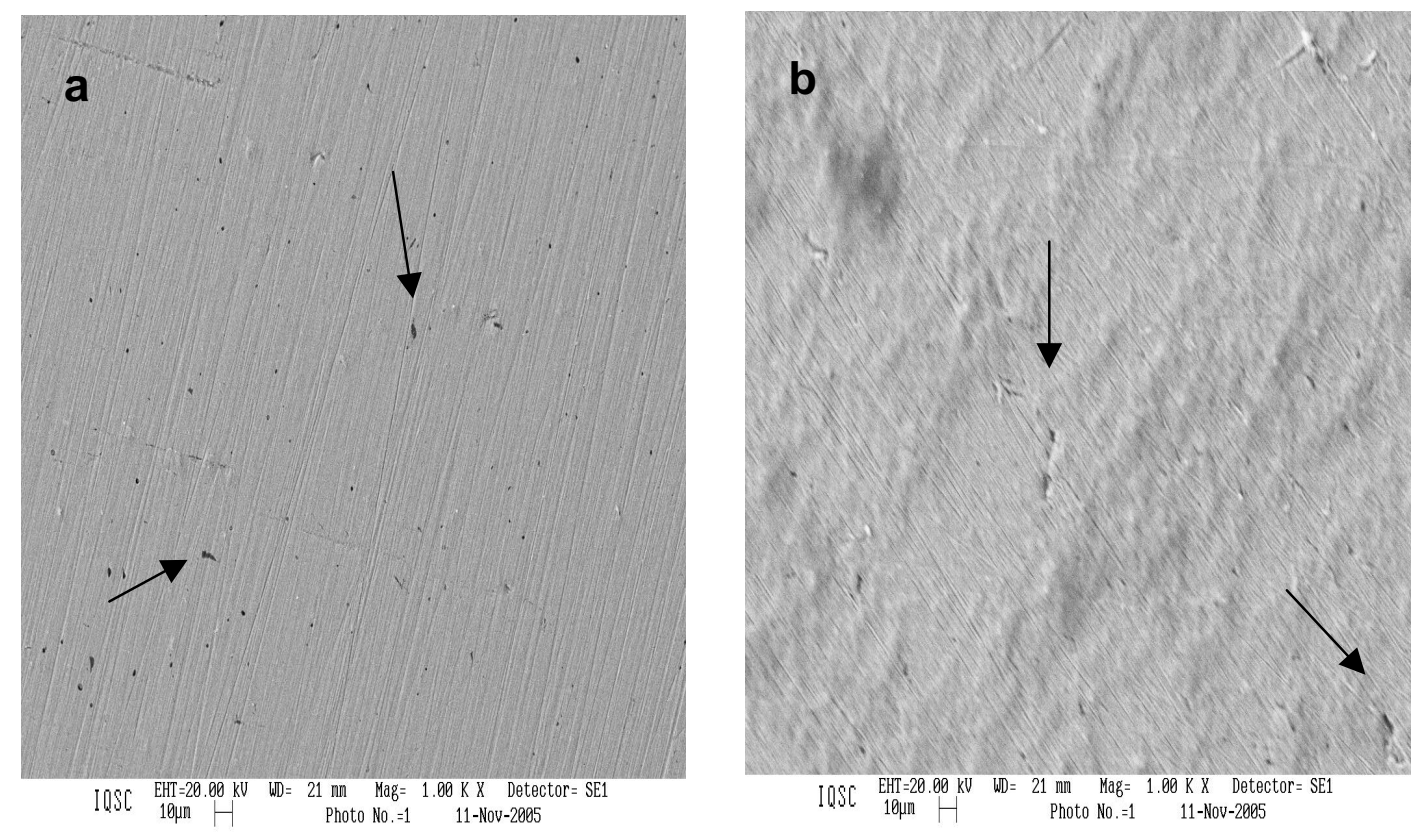

Figura 27 - Microscopia eletrônica de varredura, com aumento de 1000 vezes, para: (a) aço AISI 304 antes da polarização e (b) após a polarização potenciodinâmica.

Pode ser observada na Figura 27a a presença de riscos, provenientes do polimento mecânico e os pontos marcados pela seta, que podem ser atribuídos a defeitos estruturais. Na Figura 27b é observado que a amostra sofreu corrosão ativa quando submetida ao ataque por íons cloreto. É mostrado que a superfície foi atacada, sendo evidenciado pela presença de pites (pontos marcados pela seta) e de outras deformações superficiais que não aparecem na amostra sem ataque.

\section{4.2 - Aço AISI 430}

Para caracterizar o aço AISI 430, utilizou-se a técnica de polarização potenciodinâmica, onde o aço foi imerso em uma solução de $\mathrm{NaCl} 3 \%$ aerada, submetido a uma varredura de potenciais de $0,5 \mathrm{mV} \mathrm{s}^{-1}$, em um intervalo de potenciais de $-0,6 \mathrm{a}+0,3 \mathrm{~V}$, em relação ao ECS.

Pode se observar na Figura 28, que o aço AISI 430, possui um comportamento semelhante ao aço AISI 304, ou seja, possui um comportamento ativo depois do potencial de corrosão, com um ligeiro aumento na densidade de corrente no sentido positivo da varredura de potenciais. 
No ponto (A) da Figura 28, é mostrado o potencial de corrosão, $\mathrm{E}_{\text {corr }}=-0,195 \mathrm{~V}$, para essa liga, neste ponto ocorre à dissolução do metal e a formação das camadas de óxidos metálicos presentes na composição do aço. No ponto (B) é observada a dissolução das camadas de óxidos metálicos (ferro e cromo) e conseqüente é observado o potencial de pite, $E_{\text {pite }}=0,094 \mathrm{~V}$, a partir desse ponto à densidade de corrente volta a aumentar até atingir o ponto (C), inicio da região transpassiva. Com o auxílio do programa M352 foi calculada a taxa de corrosão (T.C.) em micrômetros por ano ( $\mu \mathrm{ma}$ ), sendo este valor igual a 6,90 $\mu \mathrm{ma}$.

Alguns autores [58,90], descrevem ensaios de polarização potenciodinâmica com o aço inoxidável AISI 430, onde os parâmetros eletroquímicos obtidos como, por exemplo, potencial de corrosão $\left(E_{\text {corr }}=-0,2 \mathrm{~V}\right)$ está em concordância com os valores obtidos para a curva acima descrita.

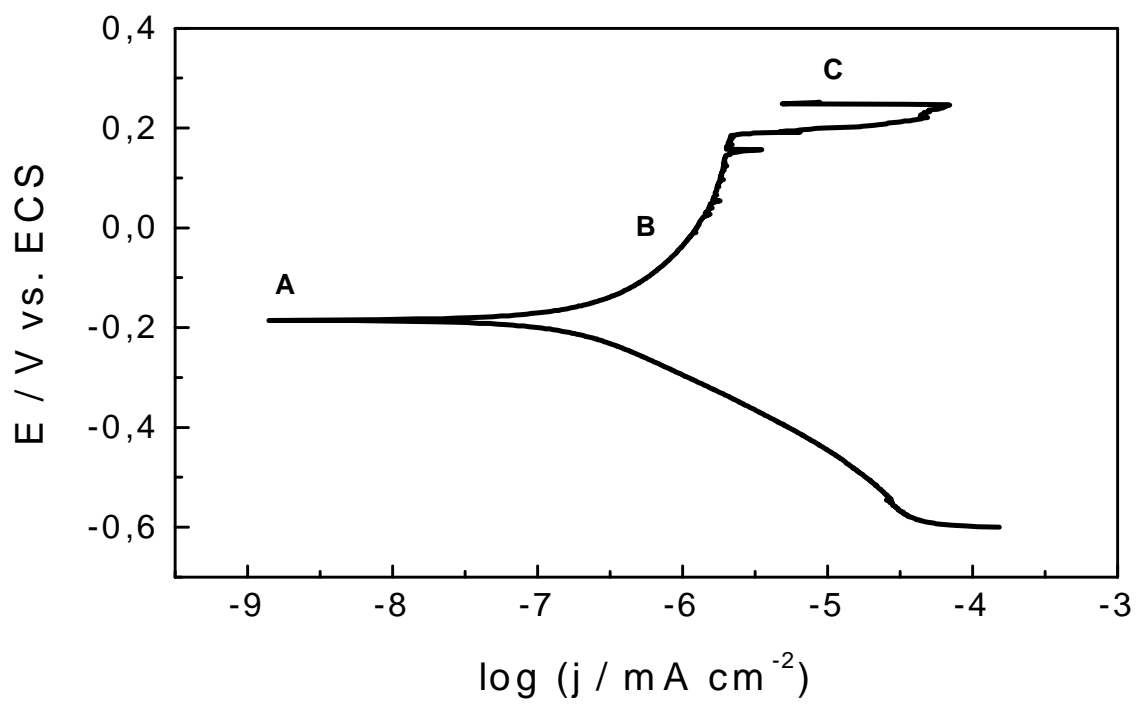

Figura 28 - Curva de polarização potenciodinâmica do aço AISI 430, em solução de $\mathrm{NaCl} 3 \%$, com velocidade de varredura de $0,5 \mathrm{mVs}^{-1}$.

A análise morfológica da superfície do aço AISI 430 foi realizada por MEV, como pode ser observado na Figura 29.

Pode ser observada na Figura 29a a presença de riscos, provenientes do polimento mecânico e o ponto marcado pela seta, que podem ser atribuídos a defeitos estruturais. Na Figura $29 \mathrm{~b}$ é observada a grande quantidade de riscos, 
devido ao polimento mecânico. É salientado, também, que a amostra sofreu corrosão quando submetida ao ataque por íons cloreto. Isto pode ser observado pelos pontos marcados pelas setas que indicam a presença de pites.
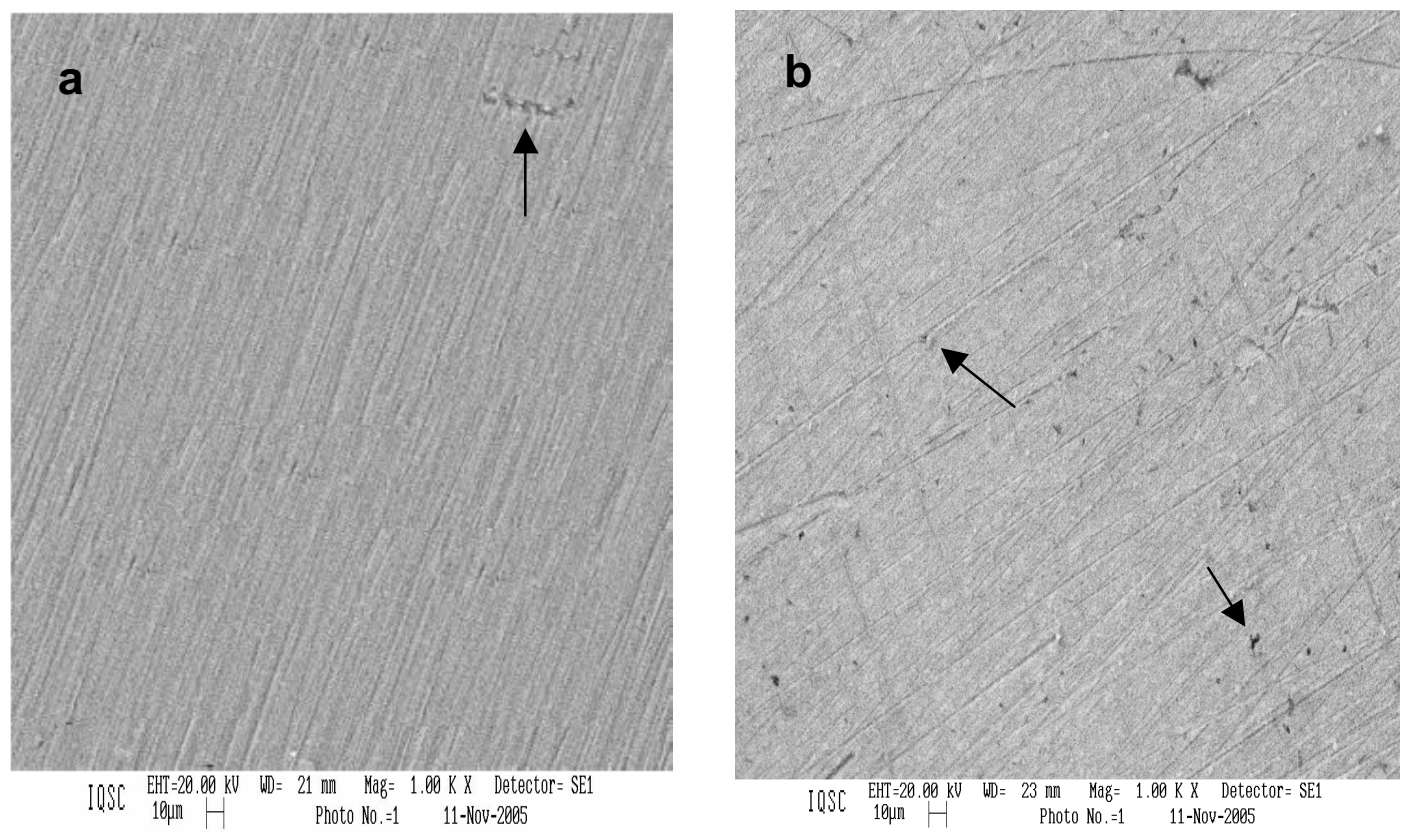

Figura 29 - Microscopia eletrônica de varredura, com aumento de 1000 vezes, para: (a) aço AISI 430 antes da polarização e (b) após a polarização potenciodinâmica.

\section{4.3 - Aço AISI 420}

Com a finalidade de se obter os parâmetros eletroquímicos desta liga, foi realizada uma curva de polarização potenciodinâmica em solução de $\mathrm{NaCl} 3 \%$, onde se fez uma varredura de potenciais de $0,5 \mathrm{mV} \mathrm{s}^{-1}$, em um intervalo de potenciais variando de $-0,6 \vee$ a $0,3 \vee$ em relação ao ECS.

Observando a Figura 30, verifica-se que o aço AISI 420 apresenta um comportamento ativo, depois do potencial de corrosão. A densidade de corrente também aumenta no sentido positivo da varredura de potenciais. Este comportamento é análogo ao descrito para os aços AISI 304 e AISI 430, diferenciando apenas nos valores dos parâmetros eletroquímicos. 


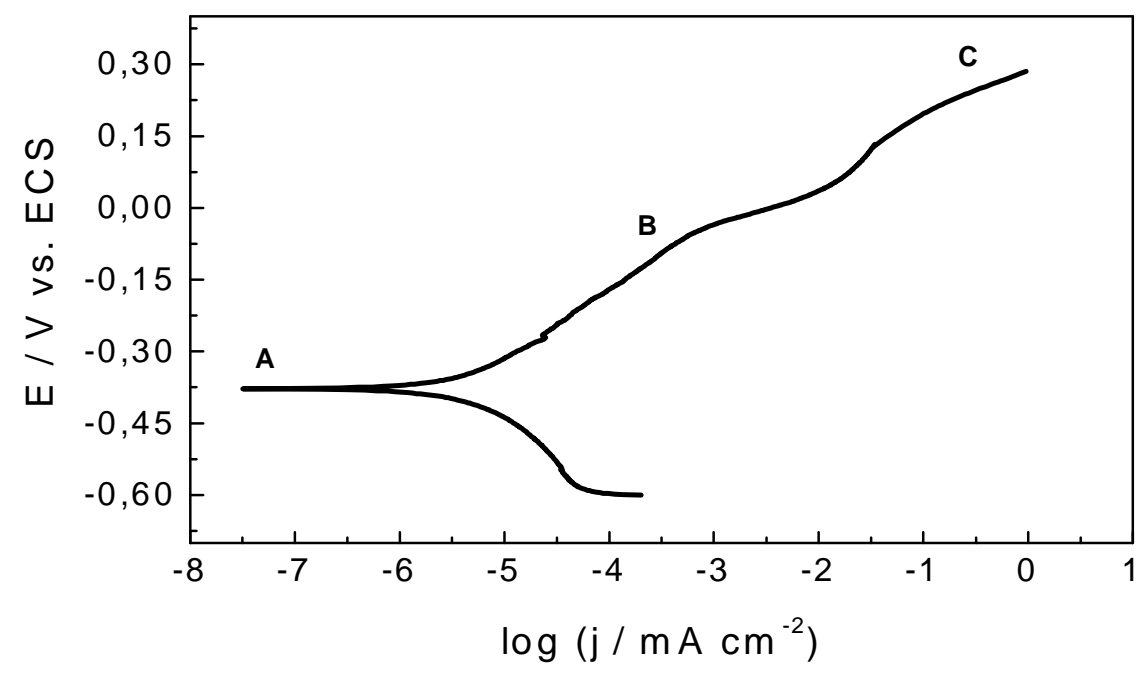

Figura 30- Curva de polarização potenciodinâmica do aço AISI 420, em solução de $\mathrm{NaCl} 3 \%$, com velocidade de varredura de $0,5 \mathrm{mVs}^{-1}$.

Para o aço inoxidável AISI $420 \quad 0$ potencial de corrosão foi $E_{\text {corr }}=-0,377 \mathrm{~V}$ e seu potencial de pite em $E_{\text {pite }}=-0,039 \mathrm{~V}$. Verifica-se na curva potenciodinâmica que a dissolução do metal ocorre no ponto $(A)$, sendo este ponto chamado de região ativa. Próximo ao ponto (B) é observado a densidade de corrente passiva. Neste estágio, a película isolante, formada principalmente por óxidos de ferro e possivelmente e uma camada, em menor quantidade, de óxido de cromo se dissolve, desta forma, chegando no potencial de pite. A densidade de corrente de corrosão volta a aumentar até chegar no potencial onde se atinge a região transpassiva (C). Com o auxílio do programa M352 foi calculada a taxa de corrosão (T.C.) em micrômetros por ano $(\mu \mathrm{ma})$, sendo este valor igual a 10,33 $\mu \mathrm{ma}$. Zhu et al. [91], realizaram curvas de polarização potenciodinâmicas do aço AISI 420, onde foram apresentados resultados como o valor do $E_{\text {corr }}=0,35 \mathrm{~V}$. Este valor apresentado pelos autores foi similar aos resultados apresentados neste estudo.

A Figura 31 apresenta as imagens microscópicas da superfície do aço AISI 420 , antes e após o processo de corrosão. 

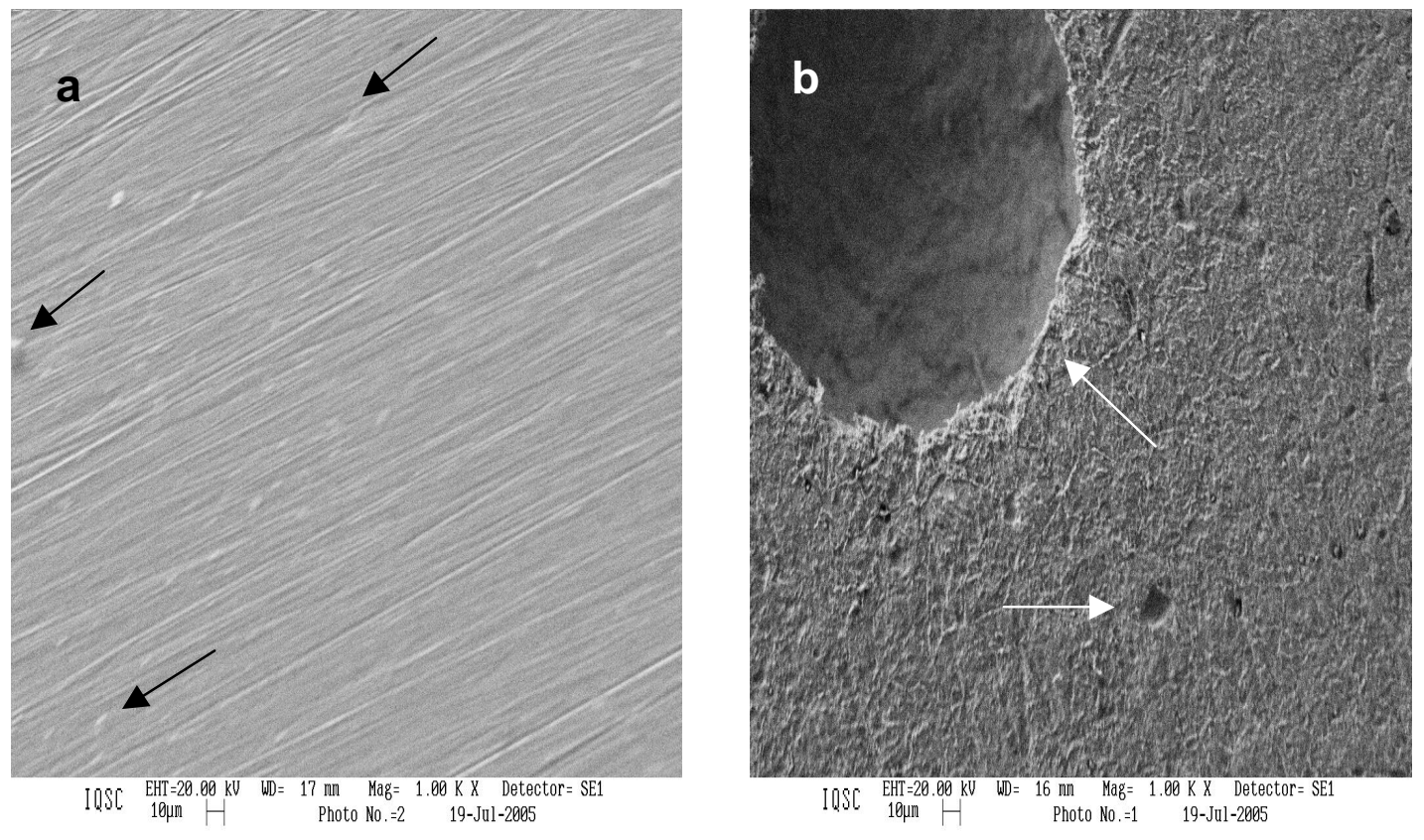

Figura 31- Microscopia eletrônica de varredura, com aumento de 1000 vezes, para: (a) aço AISI 420 antes da polarização e (b) após a polarização potenciodinâmica.

Na Figura 31a pode ser observada a presença de riscos, provenientes do polimento mecânico e defeitos estruturais (o ponto marcado pela seta). Entretanto, na imagem (b) é observado que uma grande variação da morfologia da superfície do aço, em relação à amostra antes da corrosão, devido aos processos de corrosão por pites indicados pelas setas.

Nos três aços inoxidáveis estudados, existe uma diferenciação nos valores dos parâmetros eletroquímicos obtidos através das curvas de polarização potenciodinâmica, como pode ser observado na Tabela III.

Tabela III - Parâmetros eletroquímicos obtidos através das curvas de polarização potenciodinâmica em solução de $\mathrm{NaCl} 3 \%$ aerada.

\begin{tabular}{c|c|c|c|c}
\cline { 2 - 5 } & $\mathbf{E}_{\text {corr }} / \mathbf{V}$ & $\mathbf{E}_{\text {pite }} / \mathbf{V}$ & $\mathbf{i}_{\text {corr }} / \mu \mathbf{A ~ \mathbf { c m } ^ { - 2 }}$ & T.C. $/ \mu \mathbf{m} \mathbf{~ a n o ~}^{-1}$ \\
\hline AISI 304 & $-0,180$ & $+0,094$ & 0,730 & 7,20 \\
\hline AISI 430 & $-0,195$ & $-0,004$ & 0,445 & 6,90 \\
\hline AISI 420 & $-0,377$ & $-0,039$ & 3,845 & 10,33 \\
\hline
\end{tabular}


$\mathrm{Na}$ Tabela III pode ser observado que o potencial de corrosão para os aços AISI 304 e AISI 430, tem valores de potencial de corrosão mais positivos do que para o aço AISI 420. Esta diferença pode ser atribuída ao teor de cromo presente na composição desses aços, como visto na seção 3. 4.

Os aços com maior quantidade de cromo em sua composição resistem à corrosão devido à formação de um filme superficial fino de óxido de cromo $\left(\mathrm{CrO}_{3}\right)$ [16]. Desta forma, fica evidenciado que a película protetora originária do óxido de cromo, confere um fator de proteção maior para os aços AISI 304 e AISI 430, fazendo com que esses aços possuam valores de potenciais corrosão e de pite mais positivos do que para o aço AISI 420.

Outras características que podem ser atribuídas ao teor de cromo na microestrutura desses aços é que a taxa de corrosão (TC), ou seja, a velocidade com que o metal se degrada, para o aço martensítico (AISI 420) é maior do que para os demais aços estudados. Outra característica é verificada na análise microscópica da superfície desses aços, quando estes foram submetidos a processos de corrosão. Pode se observar que a superfície do aço AISI 420, Figura 31b, foi mais atacada pelo agente corrosivo (íons cloreto) do que os aços austeníticos e ferríticos, Figuras 27b e Figura 29b respectivamente.

Desta forma, o teor de cromo presente na microestrutura dos aços inoxidáveis estudados, tem fundamental importância na diferenciação das características corrosivas de cada aço, assim como no mecanismo de deposição eletroquímica de PAni, que será apresentado nos capítulos seguintes.

\section{5 - Ensaios de corrosão}

Nesta seção são apresentados os resultados referentes à aplicação dos polímeros de PAni, como agente protetor de aços inoxidáveis contra a corrosão. Inicialmente serão apresentados os resultados referentes ao comportamento protetor dos filmes sobre os aços. Os ensaios de corrosão foram realizados em meio de $\mathrm{NaCl}$ $3 \%$, aerado, para os aços com e sem recobrimento. Assim, as curvas de polarização potenciodinâmicas dos metais foram realizadas e os efeitos protetores dos filmes de PAni observados para os polímeros nas formas dopada e desdopada, pelos 
parâmetros eletroquímicos, tais como, potencial de corrosão, potencial de pite, densidade de corrente de corrosão e taxa de corrosão por ano.

\section{5.1 - Ensaios de corrosão com o aço AISI 304}

As amostras de aço inoxidável AISI 304, sem recobrimento e recobertos com filme de PAni dopados e desdopados, foram submetidas à teste de corrosão, utilizando a técnica de polarização potenciodinâmica. As curvas obtidas em meio de $\mathrm{NaCl}$ 3\% podem ser observadas na Figura 32 e os parâmetros eletroquímicos obtidos delas são mostrados na Tabela IV.

Os parâmetros eletroquímicos obtidos para aço recoberto com o polímero no estado dopado e desdopado, apresentam valores de potencial de corrosão maia positivos, do que a amostra sem recobrimento, conseqüência da inibição das reações redox que ocorrem na interface metal eletrólito.

Entretanto, o filme de Pani no estado desdopado impede o acesso dos íons cloreto até o substrato de forma mais efetiva do que o filme no estado dopado. $A$ PAni no estado desdopado tem a capacidade de absorver cargas, provenientes de espécies vindas do eletrólito, assim, promovem as reações redox em sua superfície, impedindo que essas reações aconteçam no metal, alem de atuar como barreira física. Isto pode ser observado pela variação de potencial de corrosão do filme desdopado em relação ao aço sem recobrimento $\left(\Delta \mathrm{E}_{\text {corr }}=125 \mathrm{mV}\right)$ ser maior do que para o filme no estado dopado $\left(\Delta \mathrm{E}_{\text {corr }}=36 \mathrm{mV}\right)$.

Outros parâmetros observados são que o filme de PAni desdopado promove diminuições significativas no potencial de pite e na taxa de corrosão. Também é observada uma diminuição na densidade de corrente de corrosão, indicando a inibição da difusão de oxigênio através do polímero e, conseqüentemente, a inibição da reação de redução de oxigênio, evitando a corrosão do substrato. 


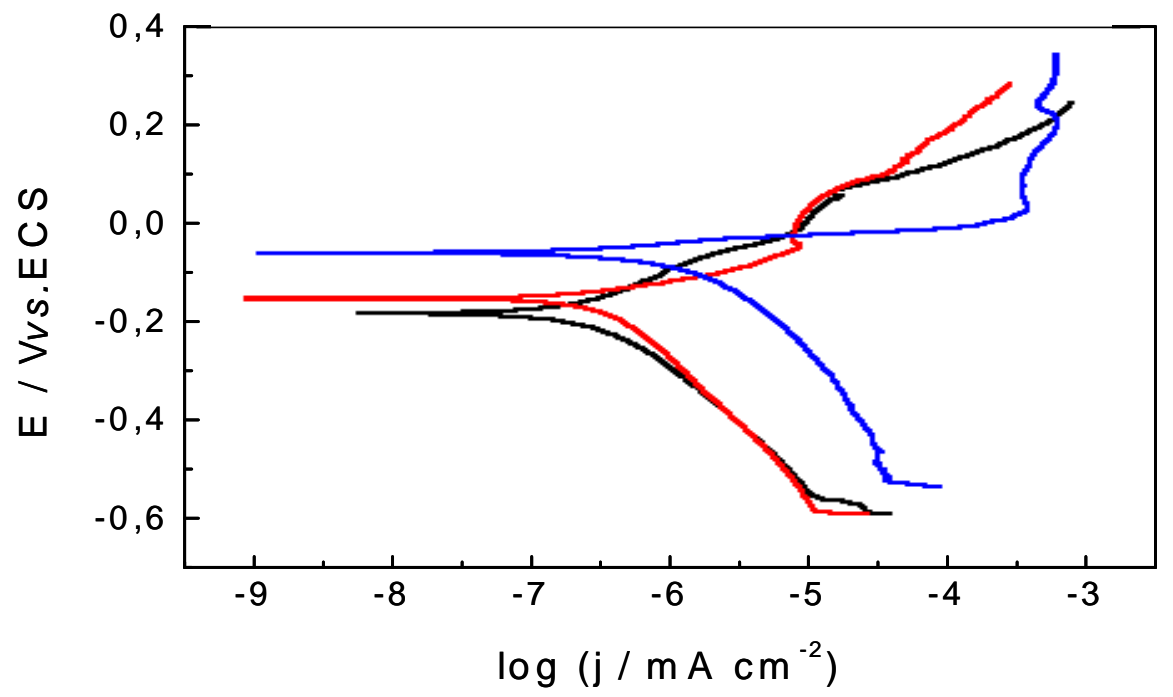

Figura 32 - Curva de polarização potenciodinâmicas, em solução de $\mathrm{NaCl} 3 \%$ aerado, com velocidade de varredura de $0,5 \mathrm{mV} \mathrm{s}^{-1}$, para o aço AISI 304: ( - sem revestimento, $(-)$ revestido com PAni dopado e $(-)$ revestido com PAni desdopado.

Tabela IV - Parâmetros eletroquímicos obtidos a partir das curvas de polarização potenciodinâmica para o aço AISI 304.

\begin{tabular}{c|c|c|c|c}
\cline { 2 - 5 } & $\mathbf{E}_{\text {corr }} / \mathbf{V}$ & $\mathbf{E}_{\text {pite }} / \mathbf{V}$ & $\mathbf{i}_{\text {corr }} / \mu \mathbf{A ~ \mathbf { c m } ^ { - 2 }}$ & T.C. $/ \mu \mathbf{m} \mathbf{a n o}^{-1}$ \\
\hline $\begin{array}{c}\text { Sem } \\
\text { revestimento }\end{array}$ & $-0,180$ & $-0,094$ & 0,730 & 7,20 \\
\hline $\begin{array}{c}\text { PAni } \\
\text { dopado }\end{array}$ & $-0,144$ & $+0,020$ & 0,658 & 6,21 \\
\hline $\begin{array}{c}\text { Pani } \\
\text { desdopado }\end{array}$ & $-0,055$ & $+0,054$ & 0,514 & 4,63 \\
\hline
\end{tabular}

O filme de PAni na forma desdopada apresentou melhores resultados como um agente protetor contra a corrosão frente a íons cloreto, desta forma, é apresentado na Figura 33, a micrografia desse filme após o processo de corrosão. A morfologia do filme pouco se altera, onde é observada (Figura 33a) a formação globular descrita anteriormente. A Figura 33b, mostra a imagem do aço, quando o filme (que foi submetido à curva de polarização anódica) foi retirado. Observa-se que não existem pontos de corrosão. 


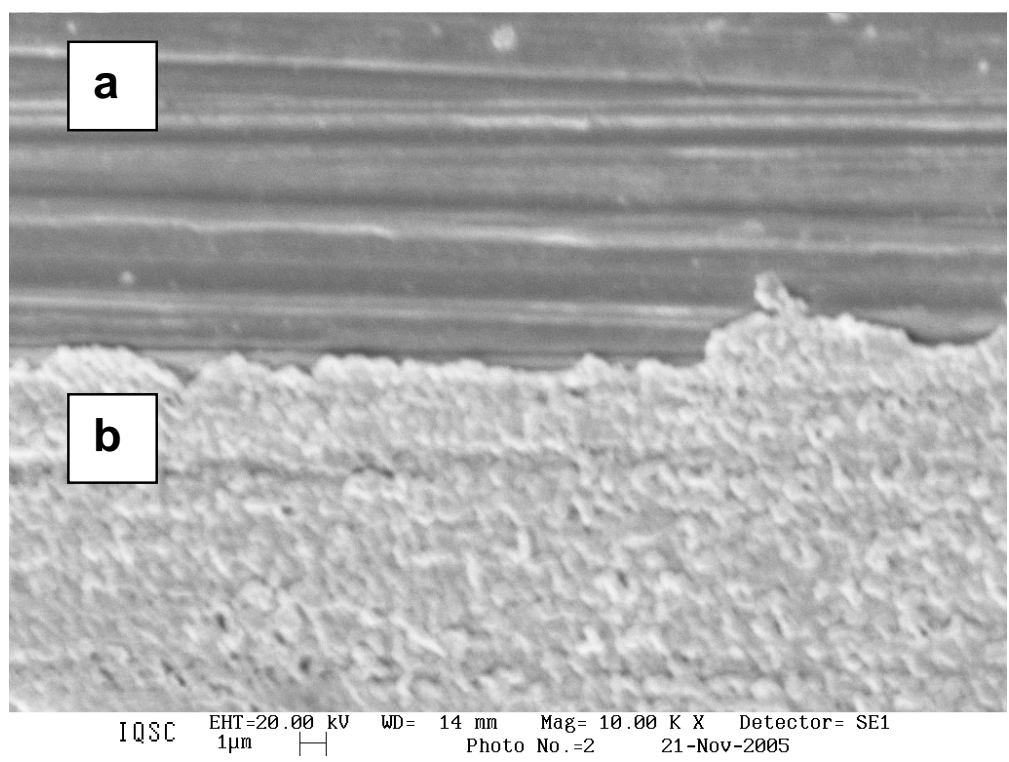

Figura 33- Micrografia do aço AISI 304 recoberto com filme de PAni no estado desdopado: (a) aço após filme de PAni ser retirado, (b) aço recoberto com filme de PAni. Ampliação de 10.000 vezes.

\section{5.2 - Ensaios de corrosão com o aço AISI 430}

Foram realizados os ensaios de corrosão para amostra do aço AISI 430 utilizando a técnica de polarização potenciodinâmica, mostrada na Figura 34 . Os parâmetros eletroquímicos extraídos desta polarização são mostrados na Tabela V.

Tabela V - Parâmetros eletroquímicos obtidos a partir das curvas de polarização potenciodinâmica para o aço AISI 430.

\begin{tabular}{c|c|c|c|c}
\cline { 2 - 5 } & $\mathbf{E}_{\text {corr }} / \mathbf{V}$ & $\mathbf{E}_{\text {pite }} / \mathbf{V}$ & $\mathbf{i}_{\text {corr }} / \mu \mathbf{A ~ \mathbf { c m } ^ { - 2 }}$ & T.C. $/ \mu \mathbf{m} \mathbf{~ a n o}^{-1}$ \\
\hline $\begin{array}{c}\text { Sem } \\
\text { revestimento }\end{array}$ & $-0,195$ & $-0,106$ & 0,455 & 6,90 \\
\hline $\begin{array}{c}\text { PAni } \\
\text { dopado }\end{array}$ & $-0,150$ & $-0,052$ & 0,358 & 5,95 \\
\hline $\begin{array}{c}\text { Pani } \\
\text { desdopado }\end{array}$ & $-0,097$ & $+0,004$ & 0,283 & 4,66 \\
\hline
\end{tabular}




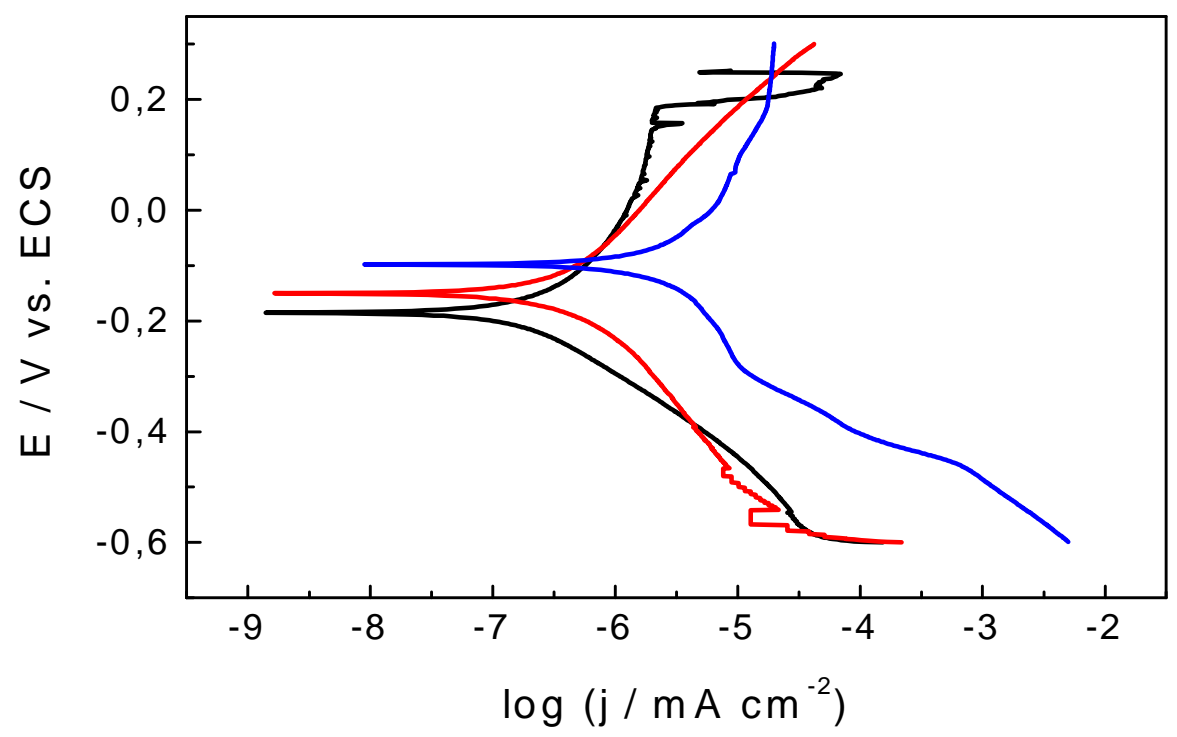

Figura 34 - Curva de polarização potenciodinâmicas, em solução de $\mathrm{NaCl} 3 \%$ aerado, com velocidade de varredura de $0,5 \mathrm{mV} \mathrm{s}^{-1}$, para o aço AISI 430: ( - sem revestimento, $(-)$ revestido com PAni dopado e $(-)$ revestido com PAni desdopado.

Os filmes de PAni atuam inibindo as reações metal/eletrólito, contudo estes filmes promovem um deslocamento de potencial de corrosão para valores mais positivos, quando comparados ao aço sem recobrimento como observado na Figura 34. O eletrodo recoberto com filme no estado desdopado apresenta melhor proteção, quando comparado com filme no estado dopado, esta afirmação se faz, quando os valores da Tabela $V$ são observados. A variação do potencial de corrosão do aço recoberto com filme desdopado em relação ao aço sem recobrimento é $\Delta \mathrm{E}_{\text {corr }}=98 \mathrm{mV}$, sendo maior do que para o filme no estado dopado, $\Delta \mathrm{E}_{\text {corr }}=35 \mathrm{mV}$. Outros fatores como as diminuições no potencial de pite e na taxa de corrosão, evidenciam a melhor proteção do filme no estado desdopado.

As análises das imagens microscópicas do filme e do metal (quando o filme é removido) mostram que não há alteração na morfologia do filme (morfologia globular) e nem o metal apresenta pontos de corrosão, como mostrado na Figura 35. 


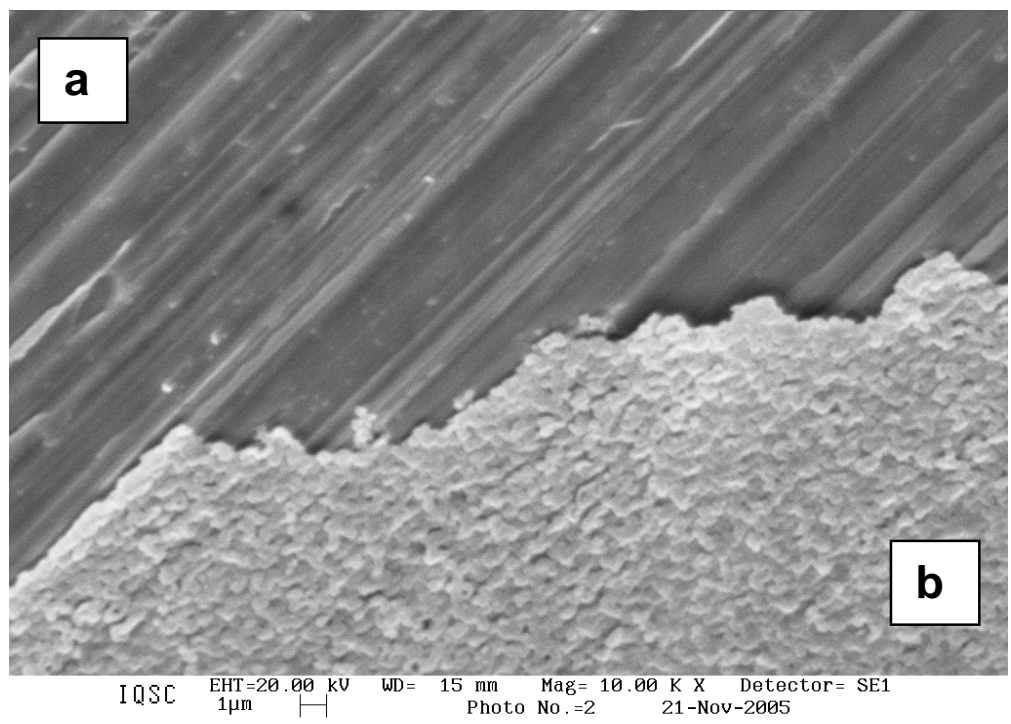

Figura 35 - Micrografia do aço AISI 430 recoberto com filme de PAni no estado desdopado: (a) aço após filme de PAni ser retirado, (b) aço recoberto com filme de PAni. Ampliação de 10.000 vezes.

\section{5.3 - Ensaios de corrosão com o aço AISI 420}

A Figura 36 mostra as curvas de polarização potenciodinâmica para os aços recobertos e sem recobrimento do filme de PAni. Os valores da Tabela VI mostram que o aço revestido com filme no estado desdopado não promove uma diferença significativa nos potencial de corrosão $\left(\Delta \mathrm{E}_{\text {corr }}=56 \mathrm{mV}\right)$ para valores mais positivos. A taxa de corrosão e o potencial de pite não diminuem de forma esperada, quando o metal está recoberto. Desta forma a interface polímero eletrólito não esta sendo eficiente na mediação entre o eletrólito e metal. 


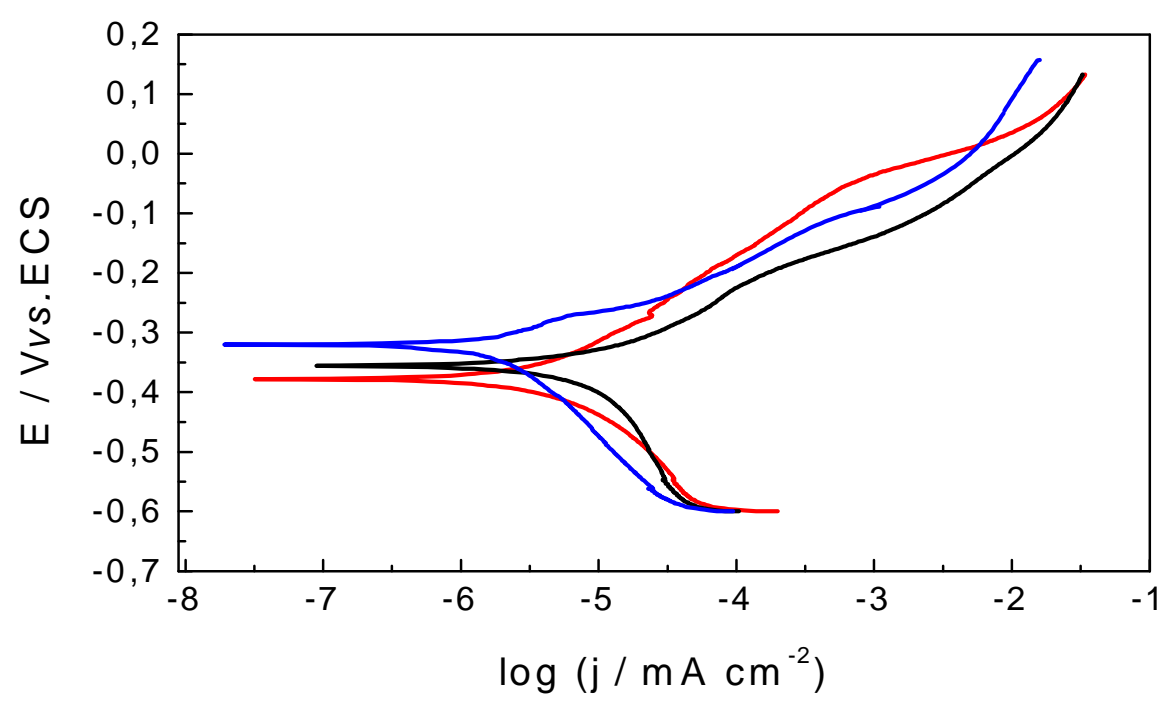

Figura 36 - Curva de polarização potenciodinâmicas, em solução de $\mathrm{NaCl} 3 \%$ aerado, com velocidade de varredura de $0,5 \mathrm{mV} \mathrm{s}^{-1}$, para o aço AISI 420: ( - sem revestimento, $(-)$ revestido com PAni dopado e $(-)$ revestido com PAni desdopado.

Tabela VI - Parâmetros eletroquímicos obtidos a partir das curvas de polarização potenciodinâmica para o aço AISI 430.

\begin{tabular}{c|c|c|c|c}
\cline { 2 - 5 } & $\mathbf{E}_{\text {corr }} / \mathbf{V}$ & $\mathbf{E}_{\text {pite }} / \mathbf{V}$ & $\mathbf{i}_{\text {corr }} / \mu \mathbf{A} \mathbf{c m}^{-2}$ & T.C. $/ \mu \mathbf{m} \mathbf{~ a n o}^{-1}$ \\
\hline $\begin{array}{c}\text { Sem } \\
\text { revestimento }\end{array}$ & $-0,377$ & $-0,325$ & 3,845 & 10,33 \\
\hline $\begin{array}{c}\text { PAni } \\
\text { dopado }\end{array}$ & $-0,354$ & $-0,298$ & 2,855 & 9,54 \\
\hline $\begin{array}{c}\text { Pani } \\
\text { desdopado }\end{array}$ & $-0,321$ & $-0,285$ & 2,356 & 8,98 \\
\hline
\end{tabular}

A natureza do filme depositado sobre do eletrodo está influenciando na relação interfacial metal/polímero/eletrólito. A grande quantidade de poros, como observado na Figura 15c, minimiza o efeito barreira do filme, facilitando a migração dos agentes corrosivos até a superfície metálica. 
A Figura 37 mostram as imagens microscópicas do filme pós-corrosão e do metal depois que o filme foi retirado da superfície do metal. A morfologia, globular com porosidade elevada, do filme de PAni no estado desdopado (Figura 36b) não se altera, entretanto na micrografia da superfície metálica (Figura 36a), observa-se alguns pontos de corrosão (pontos circulados), evidenciando que mesmo recoberto 0 aço foi atacado.
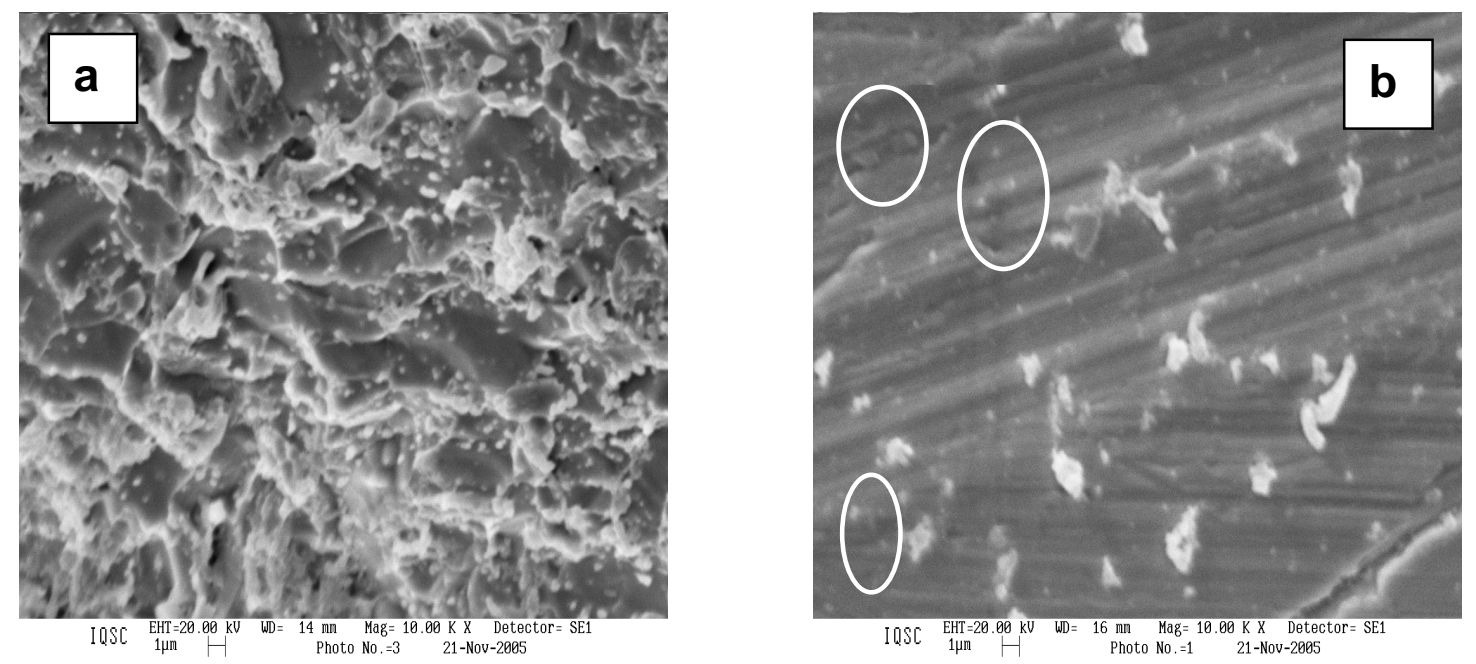

Figura 37 - Micrografia do aço AISI 420 recoberto com filme de PAni no estado desdopado: (a) filme de Pani e (b) aço sem recobrimento. Ampliação de 10.000 vezes.

\section{5.4 - Considerações gerais}

O filme de PAni no estado desdopado promove melhor proteção à corrosão aos diferentes aços estudados. Em todos os casos, os valores de potenciais de corrosão são deslocados para valores mais positivos em relação ao aço sem recobrimento. Enquanto, a densidade de corrente de corrosão, potencial de pite e taxa de corrosão são diminuídas, mostrando que o filme no estado desdopado tem atuação mais eficiente do que o filme no estado dopado. Para o filme de PAni no estado desdopado. Além de este atuar como uma barreira física, possui uma maior capacidade de dissipação de carga (elétrons).

Comparativamente, a capacidade protetora dos filmes de PAni no estado desdopado torna-se diferente para os filmes eletropolimerizados sobre os diferentes 
aços. Mediante a variação dos parâmetros eletroquímicos, foram calculadas as diferenças entre os valores de potenciais de corrosão, de pite, densidade de corrente de corrosão e taxa de corrosão dos aços recobertos com PAni desdopada e sem recobrimento, conforme demonstrados na Tabela VII.

Tabela VII - Variação dos parâmetros eletroquímicos obtidos das curvas de polarização potenciodinâmica. Relação entre ao aço revestido com PAni desdopada sem revestimento.

\begin{tabular}{c|c|c|c|c|c}
\cline { 2 - 6 } & $\mathbf{C r} \%$ & $\Delta \mathrm{E}_{\text {corr }} / \mathbf{m V}$ & $\Delta \mathrm{E}_{\text {pite }} / \mathbf{m V}$ & $\Delta \mathbf{i}_{\text {corr }} / \mu \mathbf{A ~ \mathbf { ~ c m } ^ { - 2 }}$ & $\Delta$ T.C. $/ \mu \mathbf{m ~ a n o} \mathbf{~}^{-1}$ \\
\hline AISI 304 & 18,90 & 125 & 148 & 0,22 & 2,57 \\
\hline AISI 430 & 17,10 & 98 & 110 & 0,22 & 2,24 \\
\hline AISI 420 & 12,55 & 56 & 40 & 1,49 & 1,35 \\
\hline
\end{tabular}

Para as variações dos parâmetros eletroquímicos dos aços de composição semelhante, como o AISI 304 e AISI 430 (Tabela VII) foram observados os maiores deslocamentos de potenciais de corrosão e de pites e as maiores diminuições na densidade de corrente de corrosão e taxa de corrosão. Essas variações estão concordantes aos descritos por Moraes et al. [92] e Deberry [58].

Existe um consenso de que, para que haja uma efetiva proteção contra a corrosão, o revestimento seja aderente, promova um enobrecimento ao metal, deslocando seu potencial de corrosão para valores mais positivos (cerca de $100 \mathrm{mV}$ ) e diminua a densidade de corrente e a taxa de corrosão. Desta forma, os filmes de PAni desdopados são mais eficientes em proteger os aços AISI 304 e AISI 430 contra a corrosão em meio de cloreto. Contudo, esta proteção não é observada para o aço AISI 420.

Desta forma, as diferenças na proteção que o filme de PAni proporciona para os aços, está diretamente relacionado com a natureza do substrato, que influencia na estabilidade do polímero [93].

Para os aços AISI 304 e AISI 430, cujos teores de cromo são mais elevados, os resultados de EIS, DRX e os estudos da resposta eletroquímica que relacionam as cargas, aliados aos resultados de ensaios de corrosão, constatam que a formação da camada de oxalato de ferro sobre a superfície do aço é pequena, 
proporcionando maior interação da PAni, com os pontos de ancoragem do substrato metálico (íons ferro e cromo). Esta interação é descrita em literatura como uma interação galvânica entre o ferro do substrato metálico e o filme de polianilina [94]. Este fator permite a formação de um filme mais compacto.

Entretanto, para o aço AISI 420, cujo teor de cromo é menor do que o teor dos outros aços existe a formação de uma camada espessa de oxalato. Esta espessura diminui a interação galvânica entre o substrato metálico e o polímero. Conseqüentemente, haverá a formação de um filme poroso e com aderência insatisfatória, inviabilizando o sistema PAni-oxálico na proteção, dos aços AISI 420 contra a corrosão em meio contendo íons cloreto. 


\section{Capítulo 5 \\ Conclusões e Propostas para trabalhos futuros}

\section{1 - Conclusões}

Polianilina pode ser eletropolimerizada sobre os aços inoxidáveis, a partir de solução de ácido oxálico, sendo que, síntese eletroquímica da PAni ocorre em duas etapas: a primeira etapa consiste em um ciclo de varredura de potencial em um intervalo de potenciais de $-0,6$ a 1,8 $\mathrm{V}_{\mathrm{ECS}}$ e a segunda etapa, consiste em 89 ciclos num intervalo $-0,2$ a 0,8 $V_{\mathrm{ECS}}$, com velocidade de varredura de $50 \mathrm{mV} \mathrm{s}^{-1}$.

Os resultados obtidos a partir da resposta eletroquímica da PAni, eletropolimerizada sobre os diversos aços, foram correlacionados com os relatos apresentados em literatura e indicaram que os processos observados correspondiam aos processos de formação do filme de PAni.

A análise dos espectros na região do (UV-vis-NIR) indicam que os filmes poliméricos apresentam características intrínsecas dos filmes de PAni, ou seja, os deslocamentos das bandas de absorção conforme o estado de dopagem. Esta análise demonstrou também que, não existe alteração nas bandas de absorção, quando a composição do aço é variada.

Os espectros dos polímeros na região do infravermelho mostraram características diferentes, quando a PAni está em estados de oxidação diferentes. Entretanto, os resultado demonstraram que os filmes apresentam modos vibracionais, tanto nos estados dopados e desdopados, característicos dos filmes de PAni. 
As micrografias dos filmes de PAni eletropolimerizados sobre os aços revelaram que os filmes de PAni possuem estrutura globular. Entretanto, a morfologia do filme se altera, quando a natureza do aço é alterada. Para os aços com teor de cromo elevado (AISI 304 e AISI 430) o filme se apresenta compacto e com baixa porosidade. Para o aço AISI 420, cujo teor de cromo é menor do que os demais aços, o filme se apresenta com porosidade elevada.

Os estudos que correlacionam as cargas anódicas obtidas nos estágios iniciais de polimerização da PAni, na variação da carga (processo de formação do sal esmeraldina) com a velocidade de varredura e na resposta eletroquímica em ácido oxálico, demonstraram uma tendência de aumento nos valores desta carga anódica para o aço cujo teor de cromo é menor, indicando que existe a formação de uma camada intermediária entre o substrato metálico e a PAni.

A formação desta camada foi confirmada através dos resultados de espectroscopia de impedância eletroquímica, que apresentou, nos diagramas complexos, uma componente difusional (em baixas freqüências) que é atribuída ao efeito barreira. Este efeito é conseqüência das camadas que estão depositadas sobre o eletrodo. Assim, quando os aços foram submetidos à varredura de potenciais em ácido oxálico, os aços com alto teor de cromo (AISI 304 e AISI 430), não apresentaram a componente difusional, indicativo de que a camada formada sobre os aços era pequena. Entretanto, para o aço AISI 420 foi observada a presença desta componente de processos controlados por difusão.

A formação da camada intermediária entra a PAni e os pontos de ancoragem do metal, foi observada através dos estudos de difração de raios $X$ com ângulo rasante e indicaram que esta película formada é predominantemente oxalato de ferro. O aço AISI 420 apresentou maior quantidade de raias de difração, correspondentes ao oxalato de ferro, do que para os demais aços.

Um mecanismo de eletropolimerização da PAni, sobre os aços inoxidáveis, foi proposto. Neste mecanismo é formada uma camada intermediária de oxalato de ferro entre a PAni e metal. Esta camada de oxalato é totalmente dependente da natureza do substrato metálico. A película de oxalato de ferro é menor, para aços, cujo teor de cromo é mais elevados. Assim, os filmes de PAni serão mais compactos e com baixa quantidade de poros. 
O filme de PAni desdopado demonstrou eficiência na proteção contra a corrosão dos aços inoxidáveis em meio contendo cloreto. Este filme atua como barreira física como agente dissipador de cargas, intermediando as reações redox entre o metal e o eletrólito. Outro ponto a salientar é o deslocamento do potencial de corrosão para valores mais positivos e a diminuição significativa da taxa de corrosão, quando se compara com o aço sem recobrimento.

Os ensaios de corrosão mostraram concordância com a proposição de mecanismos. Os filmes eletropolimerizados sobre os aços AISI 430 e AISI 304 apresentaram melhores resultados nos ensaios de corrosão, devido ao fato, destes filmes serem mais compactos, menos porosos do que o filme sintetizado eletroquimicamente sobre o aço AISI 420.

Desta forma, o sistema PAni-oxálico é eficiente na proteção contra a corrosão dos aços inoxidáveis AISI 304 e AISI 430, pois atua como inibidor dos processos de corrosão. Entretanto, existem restrições em se utilizar este sistema para o aço AISI 420.

\section{2 - Propostas futuras}

A partir deste trabalho fica a sugestão de otimizar o sistema PAni-oxálico como inibidor dos processos de corrosivos dos aços inoxidáveis.

Utilizar a técnica de XPS com a finalidade de complementar os resultados obtidos a partir da DRX. Esta técnica seria importante para identificar outras espécies formadas nos estágios de eletropolimerização do filme de PAni.

Verificar se existem diferenças na natureza do substrato metálico, quando se utilizam outros meios ácidos, tais como: ácido sulfúrico, ácido fosfórico ou outros ácidos inorgânicos, na eletropolimerização da PAni. 


\section{Referências Bibliográficas}

[1] KOKAWA, H. Weld decay-resistant austenitic stainless steel by grain boundary engineering. J. Mater. Sci., v. 40, p. 927-931, 2005.

[2] VERNON, W. H. The conservation of natural resoucers. London: Inst. Civil Engrs., 1978. 105 p.

[3] WONG, C. P. Polymers for electronic and photonic applications. London: Academic Press, 1993. p. 510-535

[4] MELO, C. P. Polímeros condutores. Ciência Hoje, v. 6, n. 36, p. 39-47, 1987.

[5] WATANABE, A.; MORI, K.; IWASAKI, Y.; NAKAMURA, Y.; NIIZUMA, S. Electrochromism of polyaniline film prepared by electrochemical polymerization. Macromolecules, v. 20, n. 8, p. 1793-1796, 1987.

[6] OKABAYASHI, K.; GOTO, F.; ABE, K.; YOSHIDA, T. Electrochemical studies of polyaniline and its applications. Synth. Met., v. 18, p. 365-370, 1987.

[7] YANG, C.Y.; CAO, Y.; SMITH, P.; HEELGER, A. J. Morphology of conductive, solution-processed blends of polyaniline and poly(methyl methacrylate). Synth. Met., v. 53, p. 293-301, 1993.

[8] ANDREATTA, A.; HEEGER, A. J.; SMITH, P.; Electrically conductive polyblends fibers of polyaniline and poly-(p-phenylene terephthalamide). Polym. Commun., v. 31, p. 275-278, 1990. 
[9] HSU, C. H. Novel preparation and properties of conductive polyaniline Nafion film. Synth. Met., v. 41, p. 671-674, 1991.

[10] McANDREW, T.P. Corrosion prevention with electrically conductive polymers. TRIP, v. 5, n. 1, p. 7-12, 1997.

[11] MORAES, S.R.; VILCA, D.H.; MOTHEO, A. J. Polyaniline synthesized in phosphate buffered media applied to corrosion protection. Mol.Cryst. Liq. Cryst,, v. 374, p. 391, 2002.

[12] VENANCIO, Everaldo. Carlos. Síntese e caracterização de polianilina eletropolimerizada na presença de ácido dicloroacético e tricloroacético em carbonato de propileno. 1996. 66f. Dissertação (Mestrado em Físico-Química) Instituto de Química de São Carlos, Universidade de São Paulo, São Carlos, 1996.

[13] PANTOJA, Ellen Kenia Kuntze. A eletrooxidação de compostos modelos de lignina envolvendo eletrodos modificados com polianilina. 2000. $83 f$.

Dissertação (Mestrado em Físico-Química) - Instituto de Química de São Carlos, Universidade de São Paulo, São Carlos, 2000.

[14] SANTOS JUNIOR, José Ribeiro. Síntese, caracterização e análise morfológica de polianilina eletropolimerizada na presença de diferentes ácidos. 1995. 103f Tese (Doutorado em Físico-Química) - Instituto de Química de São Carlos, Universidade de São Paulo, São Carlos, 1995.

[15] SEDRIKS, A. J. Corrosion of Stainless Steel. New York: John Wiley, 1979. $185 \mathrm{p}$.

[16] SOUZA, S. A. Composição química dos aços. São Paulo: Edgard Blücher, 1989. p. $84-101$

[17] UTILIZAÇÃO de aços inoxidáveis. Disponível em: <http://www.acesita.com.br>. Acesso em: 13 nov. 2005.

[18] PARR, J. G. HANSON, A. An Introduction to Stainless Steel. London: Chapman \& Hall, 1971. 100 p. 
[19] GENTIL, V. Corrosão. Rio de Janeiro: Editora Guanabara Dois.,1996. 432 p.

[20] FONTANA, M. G.; GREENE, N. D. Corrosion Enginneering. New York: Mc Graw Hill, 1967. 300 p.

[21] UHLIG, H. H. Corrosion and Corrosion Control. New York: John Wiley,1971. $255 \mathrm{p}$.

[22] HOAR, T. P. Electrochemical principles of the corrosion and protection of metals. J. Appl. Electrochem., v. 11, p. 121-130, 1961.

[23] POTTER, E. C. Electrochemistry. New York: Cleaver-Hume, 1956. 163 p.

[24] SHREIR, L. L. Corrosion - Metal Environment Reactions. London: NewnessButlerworths, 1976. v. 1

[25] UHLIG, H. H. The Corrosion Handbook. New York: Chapman and Hall, 1948. $785 \mathrm{p}$.

[26] GENTIL, V. Corrosão. Rio de Janeiro: Editora Guanabara Dois., 1996, 290 p.

[27] GELLING, V. J.; WIEST M. M.; TALLMAN, D. E. Electroative conducting polymers for corrosion control 4. Studies of poly(3-octyl pyrrole) and poly(3-octadecyl pyrrole) on aluminum 2024-T3 alloy. Prog. Org. Coat., v. 43, p. 149-157, 2001.

[28] KANATZIDIS, M. G. Conductive polymers. Chem. Eng. News, v. 3, p. 36-54, 1990.

[29] HUANG, W-S.; HUMPREY, B. D.; MACDIARMID, A. G. Polyaniline, a novel conducting polymer. J. Chem. Soc., Farad. Transc. I, v. 82, p. 2385-2400, 1986.

[30] MACDIARMID, A. G.; ZHENG, W. Electrochemistry of conjugated polymers and electrochemical applications. MRS Bulletin, n. 10, p. 24-30, 1997. 
[31] MAIA, J. D.; DE PAOLI, M. A.; ALVES, O. L.; ZARBIN, A. J. G.; NEVES, S. Síntese de polímeros condutores em matrizes sólidas hospedeiras. Quím. Nova, v. 23, n. 2, p. 204-215, 2000.

[32] MATTOSO, L. H. C. Polianilinas: síntese, estrutura e propriedades. Quím. Nova, v. 19, n. 4, p. 388-399, 1996.

[33] SCROSATI, B. Applications of electroactive polymers. London: Chapman \& Hall, 1993. p. 29-73

[34] YONESAWA, S.; KANAMURA, K.; TAKEHARA, Z. Discharge and charge characteristics of polyaniline prepared by electropolymerization of aniline en no aqueous solvent. J. Electrochem. Soc., v. 140, n. 3, p. 629-633, 1993.

[35] RUDGE, A.; RAISTRICK, I.; GOTTSFELD, S.; FERRARIS, J. P. A study of the electrochemical properties of conducting polymers for application in electrochemical capacitors. Electrochim. Acta, v. 39, p. 273-287, 1984.

[36] EPSTEIN, A. J.; SMALLFIELD, J. A. O.; GUAN, H.; FAHLMAN, M. Corrosion protection of aluminum and aluminum alloys by polyanilines: A potentiodynamic and photoelectron spectroscopy study. Synth. Met., v. 102, p. 1374-1376, 1999.

[37] TALLMAN, D. E.; SPINKS, G.; DOMINIS, A.; WALLACE, G. G. Electroative conducting polymers for corrosion control Part 1. General introduction and a review of non-ferrous metals. J. Solid State Eletrochem., n .6, p. 73-84, 2002.

[38] SYED, A. A.; DINESAN, M. K. Polyaniline - A novel polimeric material. Talanta, v. 38, n. 8, p. 815-837, 1991.

[39] KARYAKIN, A. A.; MALTSEV, I. A.; LUKACHOVA, L. V. The influence of defects in polyaniline structure on its electroactivity: optimization of 'self-doped' polyaniline synthesis. J. Electroanal. Chem., v. 402, p. 217-219, 1996.

[40] TRIVED, D. C. Handbook of organic conductive molecules and polymers. Chichester: John Wiley, 1997. v. 2, p. 505-571 
[41] MACDIARMID, A. G., MANOHAR, S.K., MASTERS, J. G., SUN, Y, WEISS, H., EPSTEIN, A. J. Polyaniline: Synthesis and properties of pernigraniline base. Synth. Met., v. 41-43, p. 621-626, 1991.

[42] MANOHAR, S.K.; MACDIARMID, A. G. Polyaniline: Pernigraniline, an isolable intermediate in the conventional chemical synthesis of emeraldine. Synth. Met., v. 41-43, p. 711-714, 1991.

[43] MELLO, SARITA VERA. Filmes ultrafinos de Langmuir-Blodgette automontados de polímeros condutores. 1999. $165 \mathrm{f}$. Tese (Doutorado em FísicoQuímica) - Instituto de Química de São Carlos, Universidade de São Paulo. São Carlos, 1999.

[44] NUNZIANTE, P.; PISTOIA, G. Factors affecting the growth of thick polyaniline films by the cyclic voltammetry technique. Electrochim. Acta., v. 34, n. 2, p. 223228, 1989.

[45] DIAZ, A. F. LOGAN, J. A. Electroactive polyaniline films. J. Electroanal. Chem., v. 111, p. $111-114,1980$.

[46] STILWELL, D.E.; PARK, S.M. Electrochemistry of conductive polymers.4. electrochemical studies on polyaniline degradation - product identification an coulometric studies. J. Electrochem. Soc., v .35, p. 2497-2502, 1988.

[47] ZOTTI, G.; CATTARIN, S.; COMISSO, N. Cyclic potential sweep electropolymerization of aniline the role of anions in the polymerization mechanism. J. Electroanal Chem., v. 239, p. 387-396, 1988.

[48] MU, S.; KAN, J. Energy density and IR spectra of polyaniline synthesized electrochemically in the solutions of strong acids, Synth. Met., v.98, p.51-55, 1998.

[49] LACROIX, J., C.; KANAZAWA, K. K.; DIAZ, A. Polyaniline: A very fast electrochromic material. J. Electrochem. Soc., v. 136, n. 5, p. 1254-1259, 1989. 
[50] PATIL, R. C.; PATIL, S. F.; MULLA, I. S.; VIJAYAMOHANAN, K. Effect of protonation media on chemically and electrochemically synthesized polyaniline. Polym. Int., v. 49, p. 189-196, 2000.

[51] TANG, H.; KITANI, A.; SHIOTANI, M. Electrochemical formation of polyaniline in selenic acid. J. Electrochem. Soc., v. 143, n. 10, p. 3079-3082, 1996.

[52] DHAWAN, S. K.; TRIVEDI, D. C. Electochemical behaviour of polyaniline in aromatic sulphonic acids. Polym. Int., v. 25, n. 1, p. 55-60, 1991.

[53] KARAKISLA, M.; SACAK, M.; ERDEM, E.; AKBULUT, U. Synthesis and characterization of malocnic acid-doped polyaniline. J. Appl. Electrochem., v. 27, p. 309-316, 1997.

[54] INZELT, G.; HORÁNYI, G. Some problems connected wthi the study and evaluation of the effect of ph and electrolyte concentration on the behaviour of polyaniline film electrodes. Electrochim. Acta, v. 35, n. 1, p. 27-34, 1990.

[55] ZHANG, A.Q.; CUI, C.Q.; LEE, J.Y. Electrochemical degradation of polyaniline in $\mathrm{HClO}_{4}$ and $\mathrm{H}_{2} \mathrm{SO}_{4}$. Synth. Met., v. 72, p. 217-223, 1995.

[56] STILWELL, D. E.; PARK, S. M. Electrochemistry of conductive polymers. III. Some physical and eletrochemical properties observed from electrochemically grown polyaniline. Electrochem. Soc., v. 135, n. 10, p. 2491-2496, 1988.

[57] DESILVESTRO, J.; SCHEIFELE, W. Morphology of electrochemically prepared polyaniline - influence of polymerization parameters. J. Mat. Chem., v. 3, p. 263-272, 1993.

[58] DEBERRY, D. W. Modification of the electrochemical and corrosion behavior of staineless steels with an electroactive coating. J. Electrochem. Soc., v. 132 p. 1022-1026, 1985.

[59] BERNARD, M. C.; HUGOT-LEGOFF, A; JOIRET, S. Polyaniline layer for iron protectionin sulfate medium. Synth. Met., v. 102, p. 1383-1384, 1999. 
[60] CAMALET, J. L.; LACROIX, J. C.; AEIYACH, S.; LACAZE, P. C. Characterization of polyaniline films electrodeposited on mild steel in aqueous $p$ toluenesulfonic acid solution. J. Electroanal. Chem., v. 445, p. 117-124, 1998.

[61] WRANGLEN, G. An introduction to corrosion and protection of metals. New York: Chapman and Hall, 1985. 288 p.

[62] WESSLING, B.; POSDORFER, J. Corrosion prevention with an organic metal (polyaniline): corrosion test results. Electrochim. Acta, v. 44, p. 2139-2147, 1999.

[63] CAMALET, J. L.; LACROIX, J. C.; AEIYACH, S.; CHANE-CHING, K.; LACAZE, $P$. C. Electrosynthesis of adherent polyaniline films on iron and mild steel in aqueous oxalic acid medium. Synth. Met., v. 93, p. 133-142, 1998.

[64] SANKARA-NARAYANAN, T. S. N. Influence of various factors on phosphatability -An overview. Met. Finish., p. 86-90, 1986.

[65] SAZOU, D.; GEORGOLIOS, C. Formation of conducting polyaniline coatings on iron surfaces by electropolymerization of aniline in aqueous solutions. J. Electroanal. Chem., v. 429, p. 81-93, 1997.

[66] CAMALET, J. L.; LACROIX, J. C.; AEIYACH, S.; CHANE-CHING, K.; LACAZE, P. C. Electrodeposition of protective polyaniline films on mild steel. J. Electroanal. Chem., v. 416, p. 179-182, 1996.

[67] BECK, F.; MICHAELIS, R.; SCHLOTEN, F.; ZINGER, B. Film forming electropolimerization of pyrrole on iron in aqueous oxalic acid. Electrochim. Acta, v. 39, n. 2, p. 229-234, 1994.

[68] AHMAD, N.; MACDIARMID, A. G. Inhibition of corrosion of steels with the exploitation of conducting polymers. Synth. Met., v. 78, p. 103-110,1996.

[69] SANTOS JUNIOR, J. R.; MATTOSO, L. H. C.; MOTHEO, A. J. Investigation of corrosion protection of steel by polyaniline films. Eletrochim. Acta, v. 43, n. 3-4, p. 309-313, 1998. 
[70] TALLMAN, D. E.; SPINKS, G.; DOMINIS, A.; WALLACE, G. G. Electroative conducting polymers for corrosion control Part 2. Ferrous metals. J. of Solid State Eletrochemistry, n. 6, p. 85-100, 2002.

[71] STANDARD test method for optical emission spectrometric analysis of stainless type 18-8 steels by the point-to-plane technique. Philadelphia: ASTM, 1994, p.1-4. E327-94.

[72] SAMUI, A. B.; PATANKAR, A. S.; RANGARAJAN, J.; DEB, P. C. Study of polyaniline containing paint for corrosion prevention. Prog. Org. Coat., v. 47, p. 1-7, 2003.

[73] REHIM, S. S.; HASSAN, H. H.; AMIN, M. A. Corrosion and corrosion inhibition of $\mathrm{Al}$ and some alloys in sulphate solutions containing halide ions investigated by an impedance technique. Appl. Surf. Sci., v. 187, p. 279-290, 2002.

[74] RAMANATHAN, L. V. Corrosão e seu controle. São Paulo: Hemus, 1979. 339 p.

[75] PANTOJA, MARCOS FEITOSA. Síntese eletroquímica e caracterização de polímeros provenientes de misturas de anilina e o-metoxi-anilina. 1998. $78 \mathrm{f}$. Dissertação (Mestrado em Físico-Química) - Instituto de Química de São Carlos, Universidade de São Paulo. São Carlos, 1998.

[76] ATKINS, P. W. Physical Chemistry. Oxford: Oxford University Press, 1994. $1031 \mathrm{p}$.

[77] STILWELL, D. E.; PARK, S. M. Electrochemistry of conductive polymers. In situ spectroelectrochemical studies of polyaniline films. J. Electrochem. Soc., v. 136, n. 2, p. 427-432, 1989.

[78] CAMPBELL, D.; WHITE, J. R. Polymer caracterization-physical techniques. London: Chapman \& Hall, 1991. p. 43-84.

[79] GOLDSTEIN, J. I. Scanning electron microscopy and x-ray microanalysis. A text for biologists, materials scientists and geologists. New York: Plenum, 1992. $821 \mathrm{p}$. 
[80] LOVEDAY, D.; PETERSON, P.; RODGERS, B. Evaluation of organic coatings with electrochemical impedance spectroscopy. Part 1: Fundamentals of electrochemical impedance spectroscopy. J. Coat. Tech, p. 46-52, 2004.

[81] MAHAN, B. M.; MEYERS, R. J. Química um curso universitário. São Paulo: Edgard Blücher, 1995. 530 p.

[82] MORAES, S. R.; HUERTA-VILCA, D.; MOTHEO, A. J. Characteristics of polyaniline synthesized in phosphate buffer solution. Eur. Polym. J., v. 40, p. 2033-2041, 2004.

[83] MOTHEO, A. J.; HUERTA-VILCA, D.; MORAES, S. R. Processo de recobrimento de metais com múltiplas camadas de polianilina eletropolimerizada. BR n. PI0103373-5, 20 jun. 2001.

[84] KANG, E. T.; NEOH, K. G.; TAN, K. L. Polyaniline: A polymer with many interesting intrisic redox states. Prog. Polym. Sci., v. 23, p. 277-324, 1998.

[85] CHEN, Y.; KANG, E. T.; NEOH, K. G. Electroless polymerization of aniline on platinum and palladium surfaces. Appl Surf. Sci., v. 185, p. 267-276, 2002.

[86] SAZOU, D . Electrodeposition of ring-substituted polyanilines on Fe surfaces from aqueous oxalic acid solutions and corrosion protection of Fe. Synth. Met. v. 118, p. 133-147, 2001.

[87]. MELKIOR, T.; MOURZAGH, D.; YAHIAOUI, S.; THOBY, D.; ALBERTO, J. C.; BROUARD, C.; MICHAU, N. Diffusion of an alkaline fluid through claye barriers and its effect on the diffusion properties of some chemical species. Appl. Clay Sci., v. 26, p. 99-107, 2004.

[88] BONNEL, K.; LE PEN, C.; PÉBÈRE, N. E.I.S. charecterization of protective coatings on aluminium alloys. Electrochim. Acta, v. 44, p. 4259-4267, 1999.

[89] LOPEZ, D.; SANCHEZ, C.; TORO, A. Corrosion-erosion behavior of TiN-coated stainless steels in aqueous slurries. WEAR, v. 258, p. 684-692, 2005. 
[90] BETOVA, I.; BOJINOV, M.; KANAZIRSKI, I.; TZVETKO, T. Transpassive dissolution of ferritic steels in a molten salt electrolyte. Electrochem. Comm.; v. 6, p. 1206-1211, 2004.

[91] ZHU, H.; ZHONG, L.; XIAO, S.; GAN, F. Accelerating effect and mechanism of passivation of polyaniline on ferrous metals. Electrochim. Acta, v. 49, p. 5161-5166, 2004.

[92] MORAES, S. R.; HUERTA-VILCA, D.; MOTHEO, A. J. Corrosion protection of stainless steel by polyaniline electrosynthesized from phosphate buffer solution.

Prog. Org. Coat. v. 48, p. 28-33, 2003.

[93] FENELON A. N.; BRESLIN, C. B. An investigation into degradation of polyaniline films grown on iron from oxalic acid. Synth. Met.,v. 144, p. 125-131, 2004.

[94] LU, W. K.; ELSENBAUMER, R. L.; WESSLING, B. Corrosion protection of mildsteel by coating containing polyaniline. Synth. Met., v. 71, n. 1-3, p. 2163-2168, 1995. 